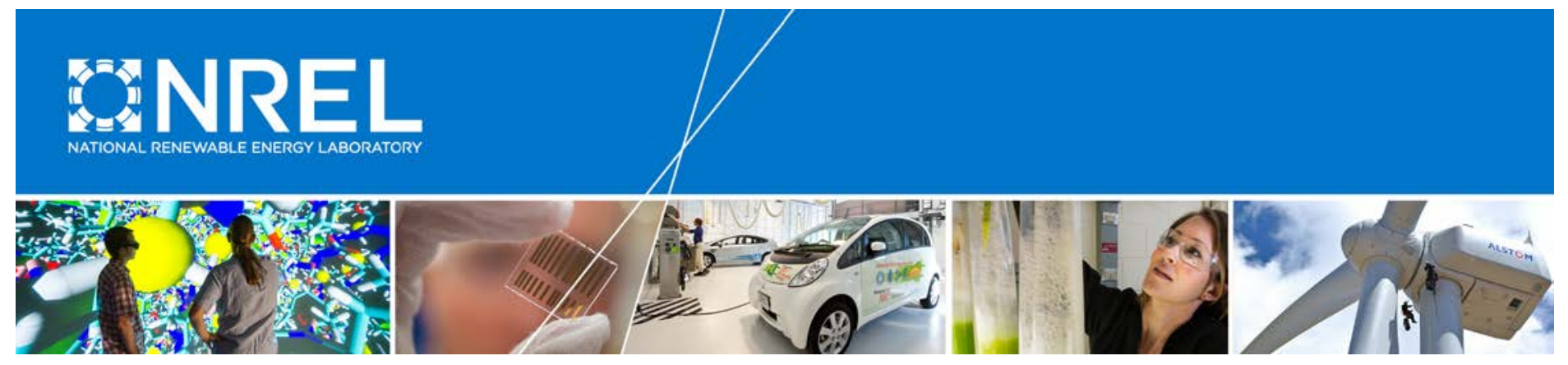

\title{
Zero Emission Bay Area (ZEBA) Fuel Cell Bus Demonstration Results: Fourth Report
}

Leslie Eudy and Matthew Post National Renewable Energy Laboratory

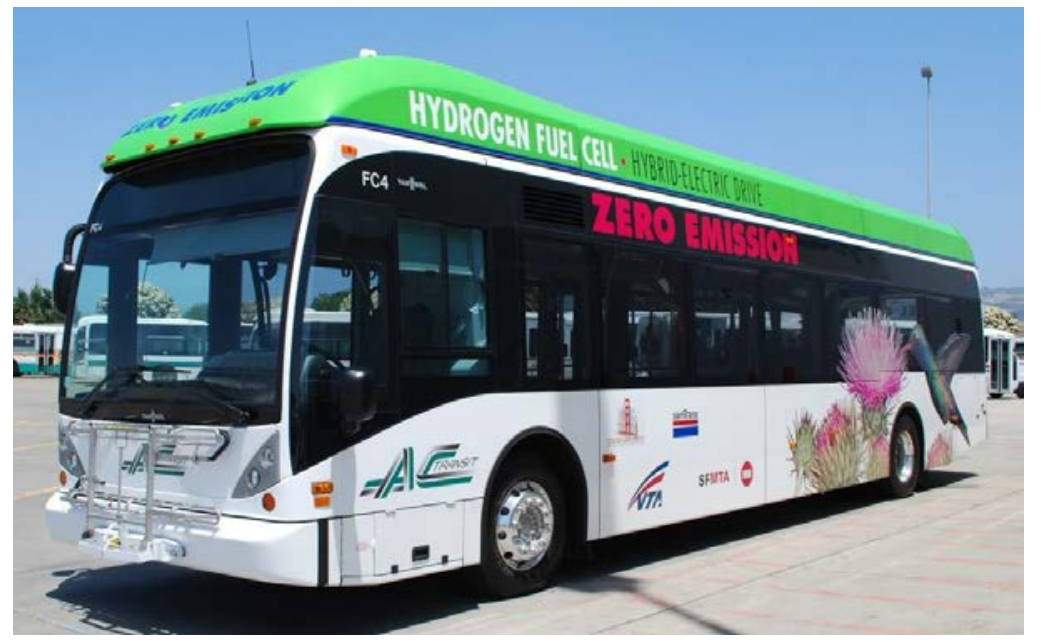

NREL is a national laboratory of the U.S. Department of Energy Office of Energy Efficiency \& Renewable Energy Operated by the Alliance for Sustainable Energy, LLC

This report is available at no cost from the National Renewable Energy Laboratory (NREL) at www.nrel.gov/publications.

Technical Report

NREL/TP-5400-63719

July 2015

Contract No. DE-AC36-08GO28308 


\section{Zero Emission Bay Area (ZEBA) Fuel Cell Bus Demonstration Results: Fourth Report}

Leslie Eudy and Matthew Post National Renewable Energy Laboratory

Prepared under Task No. HT12.8210
NREL is a national laboratory of the U.S. Department of Energy Office of Energy Efficiency \& Renewable Energy Operated by the Alliance for Sustainable Energy, LLC

This report is available at no cost from the National Renewable Energy Laboratory (NREL) at www.nrel.gov/publications.

\section{Technical Report}

NREL/TP-5400-63719

July 2015

Contract No. DE-AC36-08G028308
15013 Denver West Parkway

Golden, CO 80401

303-275-3000 • www.nrel.gov 


\title{
NOTICE
}

This report was prepared as an account of work sponsored by an agency of the United States government. Neither the United States government nor any agency thereof, nor any of their employees, makes any warranty, express or implied, or assumes any legal liability or responsibility for the accuracy, completeness, or usefulness of any information, apparatus, product, or process disclosed, or represents that its use would not infringe privately owned rights. Reference herein to any specific commercial product, process, or service by trade name, trademark, manufacturer, or otherwise does not necessarily constitute or imply its endorsement, recommendation, or favoring by the United States government or any agency thereof. The views and opinions of authors expressed herein do not necessarily state or reflect those of the United States government or any agency thereof.

This report is available at no cost from the National Renewable Energy Laboratory (NREL) at www.nrel.gov/publications.

Available electronically at SciTech Connect http:/www.osti.gov/scitech

Available for a processing fee to U.S. Department of Energy and its contractors, in paper, from:

\author{
U.S. Department of Energy \\ Office of Scientific and Technical Information \\ P.O. Box 62 \\ Oak Ridge, TN 37831-0062 \\ OSTI http://www.osti.gov \\ Phone: 865.576.8401 \\ Fax: 865.576.5728 \\ Email: reports@osti.gov
}

Available for sale to the public, in paper, from:

\author{
U.S. Department of Commerce \\ National Technical Information Service \\ 5301 Shawnee Road \\ Alexandria, VA 22312 \\ NTIS http://www.ntis.gov \\ Phone: 800.553 .6847 or 703.605 .6000 \\ Fax: 703.605.6900 \\ Email: orders@ntis.gov
}




\section{Acknowledgments}

This evaluation at Alameda-Contra Costa Transit District (AC Transit) would not have been possible without the support and cooperation of many people. The authors thank the following individuals:

U.S. Department of Energy (DOE)

Jason Marcinkoski

U.S. Department of Transportation

Federal Transit Administration

Christina Gikakis

Sean Ricketson

DOE's National Renewable Energy

Laboratory

Keith Wipke

Jen Kurtz

AC Transit

Salvador Llamas

Chris Durant

Roland Fecteau

Jose Vega

Sergio Moreno

and many others

US Hybrid

Abas Goodarzi

Reza Sarhadi-Nia

Matthew Riley
EnerDel

Tomasz Poznar

Golden Gate Transit

Steve Miller

Santa Clara Valley Transportation

Authority

Arthur Douwes

Jim Wilhelm

Christian Reif

San Mateo Transportation Agency

David Olmeda

Jerie Moeller

Linde

Nitin Natesan

Kyle McKeown

Center for Transportation and the Environment

Erik Bigelow

Unless otherwise noted, all photos and illustrations by L. Eudy, NREL 


\section{Acronyms and Abbreviations}

\begin{tabular}{ll} 
AC Transit & Alameda-Contra Costa Transit District \\
Ah & amp-hours \\
CARB & California Air Resources Board \\
DGE & diesel gallon equivalent \\
DOE & U.S. Department of Energy \\
FCEB & fuel cell electric bus \\
FCEV & fuel cell electric vehicle \\
FCPP & fuel cell power plant \\
ft & feet \\
FTA & Federal Transit Administration \\
GVWR & gross vehicle weight rating \\
hp & horsepower \\
HVAC & heating, ventilation, and air conditioning \\
in. & inches \\
kg & kilograms \\
kW & kilowatts \\
kWh & kilowatt hours \\
lb & pounds \\
MBRC & miles between roadcalls \\
mpg & miles per gallon \\
mph & miles per hour \\
NREL & National Renewable Energy Laboratory \\
PMI & preventive maintenance inspection \\
psi & pounds per square inch \\
RC & roadcall \\
SI & International System of Units \\
ZBus & zero emission bus \\
ZEBA & Zero Emission Bay Area \\
& \\
\hline &
\end{tabular}




\section{Executive Summary}

This report presents results of a demonstration of fuel cell electric buses (FCEB) operating in Oakland, California. Alameda-Contra Costa Transit District (AC Transit) leads the Zero Emission Bay Area (ZEBA) demonstration, which includes 12 advanced-design fuel cell buses and two hydrogen fueling stations. The FCEBs in service at AC Transit are 40-foot, low-floor buses built by Van Hool with a hybrid electric propulsion system that includes a US Hybrid fuel cell power system and EnerDel lithium-based energy storage system. The buses began revenue service in May 2010.

The ZEBA demonstration is the largest FCEB demonstration in the United States and involves five participating transit agencies. ${ }^{1}$ The ZEBA partners are collaborating with the U.S. Department of Energy (DOE) and DOE's National Renewable Energy Laboratory (NREL) to evaluate the buses in revenue service. NREL has been evaluating FCEBs under funding from DOE and the U.S. Department of Transportation's Federal Transit Administration (FTA). NREL uses a standard data-collection and analysis protocol originally developed for DOE heavy-duty vehicle evaluations. ${ }^{2}$ NREL has published three previous reports - in August 2011, ${ }^{3}$ July 2012, ${ }^{4}$ and May $2014^{5}$ - describing operation of these buses. New results in this report provide an update covering data from November 2013 through December 2014.

The focus of this evaluation is to compare performance of the FCEBs to that of conventional technology and to track progress over time toward meeting the technical targets set by DOE and FTA. In the commercialization process that begins at technology readiness level (TRL) 1-basic research/concept—and ends at TRL 9-commercial deployment, NREL considers the ZEBA buses to be at TRL 7. At this point of development, the manufacturers' goals for the demonstration are to verify that the FCEB performance meets the technical targets and identify any issues that need to be resolved. NREL collects data on two different conventional bus types for a baseline comparison at AC Transit: Van Hool diesel buses that are the same model as the FCEBs and newer Gillig diesel buses.

Since the last report, there have been multiple accomplishments.

- The FCEBs have operated 969,145 miles and 110,832 hours on the fuel cell power systems and have used 122,944 $\mathrm{kg}$ of hydrogen.

- The Oakland hydrogen station was completed and a portion of the fleet was moved to operate out of that division. The station, designed and built by Linde, features dispensers

\footnotetext{
${ }^{1}$ Participating agencies include AC Transit, Golden Gate Transit, Santa Clara Valley Transportation Authority, San Mateo County Transit District, and San Francisco Municipal Transportation Agency.

${ }^{2}$ Fuel Cell Transit Bus Evaluations: Joint Evaluation Plan for the U.S. Department of Energy and the Federal Transit Administration, NREL/MP-560-49342-1, November 2010, http://www.nrel.gov/docs/fy11osti/49342-1.pdf.

${ }^{3}$ Zero Emission Bay Area (ZEBA) Fuel Cell Bus Demonstration: First Results Report, NREL/TP-5600-52015, August 2011, http://www.nrel.gov/docs/fy11osti/52015.pdf.

${ }^{4}$ Zero Emission Bay Area (ZEBA) Fuel Cell Bus Demonstration: Second Results Report, NREL/TP-5600-55367, July 2012, http://www.nrel.gov/docs/fy12osti/55367.pdf.

${ }^{5}$ Zero Emission Bay Area (ZEBA) Fuel Cell Bus Demonstration Results: Third Report, NREL/TP-5400-60527, May 2014, http://www.nrel.gov/docs/fy14osti/60527.pdf.
} 
in-line with the diesel fueling island, which allows the FCEBs to be integrated into the standard process for prepping buses for the next morning pull-out.

- The twelve fuel cell power plants (FCPP) continue to accumulate high hours of service. One FCPP has surpassed the DOE/FTA 2016 target of 18,000 hours, accumulating 18,299 hours by the end of the data period for the report. This is a record number of hours documented to date on a fuel cell in a transit application. Of the remaining FCPPs, 71\% have surpassed 9,000 hours.

- AC Transit and its manufacturer partners continue to ramp up service of the FCEBs, including troubleshooting, maintenance, and training for all involved. The buses are now being operated on any route out of the two depots that are serviced by 40 -foot buses (with the exception of commuter routes).

This third results report provides data analysis summaries of FCEB operations beginning in November 2013 through December 2014. Table ES-1 provides a summary of the evaluation results presented in this report.

Table ES-1. Summary of Evaluation Results

\begin{tabular}{|c|c|c|c|}
\hline Data Item & Fuel Cell & Diesel Van Hool $^{2}$ & Diesel Gillig \\
\hline Number of buses & 12 & 4 & 10 \\
\hline Data period & $11 / 13-12 / 14$ & $11 / 13-12 / 14$ & $11 / 13-12 / 14$ \\
\hline Number of months & 14 & 14 & 14 \\
\hline Total mileage in period & 417,757 & 226,169 & 685,681 \\
\hline Average monthly mileage per bus & 2,487 & 4,349 & 4,898 \\
\hline Total fuel cell operating hours & 49,421 & $\mathrm{~N} / \mathrm{A}$ & $\mathrm{N} / \mathrm{A}$ \\
\hline Average bus operating speed (mph) & 8.5 & N/A & N/A \\
\hline Availability ( $85 \%$ is target) & 72 & 82 & 88 \\
\hline Fuel economy (miles/kg) & 6.40 & $\mathrm{~N} / \mathrm{A}$ & N/A \\
\hline Fuel economy (miles/DGE ${ }^{b}$ ) & 7.23 & 3.95 & 4.36 \\
\hline Miles between roadcalls (MBRC) - bus & 6,235 & 4,267 & 8,362 \\
\hline MBRC - propulsion only & 10,444 & 9,833 & 25,396 \\
\hline MBRC - fuel cell system only & 34,813 & $\mathrm{~N} / \mathrm{A}$ & N/A \\
\hline Fuel cost (\$/mile) & 1.42 & 0.73 & 0.66 \\
\hline Total maintenance $(\$ / \mathrm{mile})^{\mathrm{C}}$ & 0.59 & 0.68 & 0.25 \\
\hline Maintenance - propulsion only (\$/mile) & 0.24 & 0.18 & 0.06 \\
\hline $\begin{array}{l}\text { Maintenance including extended warranty } \\
\text { and extra labor costs }(\$ / \text { mile })^{\mathrm{d}}\end{array}$ & 1.33 & - & - \\
\hline
\end{tabular}

Overall, the FCEBs had an average fuel economy of 6.40 miles per kilogram of hydrogen, which equates to 7.23 miles per diesel gallon equivalent. These results indicate that the FCEBs have an average fuel economy that is $83 \%$ higher than that of the Van Hool diesel buses and 66\% higher than that of the Gillig diesel buses. Fuel cost for hydrogen remains much higher than the cost of diesel-\$9.10 per kilogram of hydrogen compared to $\$ 2.87$ per gallon for diesel. The cost of hydrogen has increased slightly since the previous report, while the average cost of diesel fuel has dropped. Fuel cost calculates to $\$ 1.42$ per mile for the FCEBs compared to $\$ 0.73$ per mile for the Van Hool diesel buses and \$0.66 per mile for the Gillig diesel buses. 
The overall availability for the FCEBs has dropped compared to what was documented in the last report $-72 \%$ compared to $82 \%$ from the previous data period. This is primarily due to extended downtime (not related to the fuel cell system) for two of the buses. The issues proved challenging to diagnose and resulted in the buses being out of service for much of the evaluation period presented in this report. The Van Hool diesel buses achieved an availability of $82 \%$ and the Gillig diesel buses had an availability of $88 \%$ during the period.

Reliability, measured as miles between roadcall (MBRC), continues to show improvement. When evaluating cumulative totals since the buses first went into service, the overall bus MBRC for the ZEBA buses is showing a slow increase over time and has surpassed the target of 4,000 miles. The fuel cell MBRC shows a steady increase and has passed the DOE/FTA 2016 target of 15,000 miles and is nearing the ultimate target of 20,000 miles.

In addition to the analysis of the FCEB performance, NREL provides a cost analysis and comparison. The current costs for FCEB technology—both capital and operating costs—are still much higher than the costs of conventional diesel technology. This is expected when comparing a very mature technology, like diesel, to new technologies in the development stage. The FCEBs are now out of the original warranty period resulting in an increase in operating costs. AC Transit has negotiated agreements with US Hybrid and EnerDel for extended warranty support.

Total maintenance costs per mile for the FCEBs during the reporting period were $13 \%$ lower than that of the Van Hool diesel buses. This is expected, considering the Van Hool buses are out of warranty and have accumulated a total mileage more than 4 times that of the FCEBs. The FCEB maintenance costs were more than 2 times higher than that of the new Gillig diesel buses. Throughout the demonstration, the ZEBA buses have incurred some costs that fall outside of the typical maintenance costs. These include labor for shuttling buses between depots, research/training activities, and fueling the buses. These are considered non-recurring costs for the FCEBs attributed primarily to the learning curve for maintenance staff. The non-recurring costs for the ZEBA fleet have dropped dramatically over the last year and add only $\$ 0.05$ per mile to the operating cost of the buses for the evaluation period in this report. Once the Emeryville maintenance bay is completed, shuttling the buses between depots will not be necessary and the costs for all non-recurring activities should be completely eliminated. When factoring in the costs for the extended warranties and other costs, the current cost to operate the FCEBs comes to $\$ 1.33$ per mile.

During the data period, one bus had a bus-related issue that kept it out of service for 14 months. The bus was repaired and went back into service in December 2014. The intermittent nature of the problem made diagnosis a challenge and resulted in the extended downtime. That bus accumulated fewer than 1,000 miles during the data period, resulting in performance that was not representative of that of the overall fleet. The performance indicators of monthly miles, availability, and costs were significantly affected by the downtime of this bus. If this bus is removed from the analysis results, the average monthly mileage increases from 2,487 to 2,707, the availability increases from $72 \%$ to $78 \%$, and the maintenance cost decreases from $\$ 0.59$ per mile to $\$ 0.48$ per mile. 
Although the performance of FCEBs has improved over time, there are still challenges that must be addressed before the technology can be considered commercial. Challenges include the following:

- Increasing durability and reliability of components

- Improving systems integration and optimization

- Providing for adequate parts supply

- Lowering cost—both capital and operating.

DOE and FTA published performance and cost targets for FCEBs. These targets, established with industry input, include interim targets for 2016 and ultimate targets for commercialization. Table ES-2 summarizes the current performance results of the ZEBA buses compared to these targets.

Table ES-2. Summary of FCEB Performance Compared to DOE/FTA Targets ${ }^{6}$

\begin{tabular}{|c|c|c|c|c|}
\hline & Units & This Report ${ }^{\mathrm{a}}$ & $\begin{array}{l}2016 \\
\text { Target }\end{array}$ & $\begin{array}{l}\text { Ultimate } \\
\text { Target }\end{array}$ \\
\hline Bus lifetime & years/miles & $\begin{array}{c}4 / \\
54,400-98,900^{b}\end{array}$ & $12 / 500,000$ & $12 / 500,000$ \\
\hline Power plant lifetime $^{c}$ & hours & $7,800-18,300^{d}$ & 18,000 & 25,000 \\
\hline Bus availability & $\%$ & 72 & 85 & 90 \\
\hline Fuel fills ${ }^{e}$ & per day & 1 & $1(<10 \mathrm{~min})$ & $1(<10 \mathrm{~min})$ \\
\hline Bus cost ${ }^{f}$ & $\$$ & $2,500,000^{g}$ & $1,000,000$ & 600,000 \\
\hline Power plant cost ${ }^{\mathrm{c}, \mathrm{f}}$ & $\$$ & $\mathrm{~N} / \mathrm{A}^{\mathrm{h}}$ & 450,000 & 200,000 \\
\hline $\begin{array}{l}\text { Hydrogen storage } \\
\text { cost }\end{array}$ & $\$$ & $N / A^{h}$ & 75,000 & 50,000 \\
\hline $\begin{array}{l}\text { Roadcall frequency } \\
\text { (bus/fuel cell system) }\end{array}$ & $\begin{array}{l}\text { miles between } \\
\text { roadcalls }\end{array}$ & $\begin{array}{l}6,200 / \\
34,800\end{array}$ & $\begin{array}{l}3,500 / \\
15,000\end{array}$ & $\begin{array}{l}4,000 / \\
20,000\end{array}$ \\
\hline Operation time & $\begin{array}{c}\text { hours per } \\
\text { day/days per } \\
\text { week }\end{array}$ & $\begin{array}{l}7-14 / \\
5-7\end{array}$ & $20 / 7$ & $20 / 7$ \\
\hline $\begin{array}{l}\text { Scheduled and } \\
\text { unscheduled } \\
\text { maintenance cost }\end{array}$ & $\$ /$ mile & 0.59 & 0.75 & 0.40 \\
\hline Range & miles & $244^{j}$ & 300 & 300 \\
\hline Fuel economy & $\begin{array}{l}\text { miles per diesel } \\
\text { gallon equivalent }\end{array}$ & 7.23 & 8 & 8 \\
\hline
\end{tabular}

${ }^{a}$ Summary of the results for the ZEBA buses in this report: data from November 2013 to December 2014.

${ }^{\mathrm{b}}$ Accumulated totals for the ZEBA buses through December 2014; these buses have not reached end of life; targets are for lifetime.

${ }^{\mathrm{c}}$ For the DOE/FTA targets, the power plant is defined as the fuel cell system and the battery system. The fuel cell system includes supporting subsystems such as the air, fuel, coolant, and control subsystems. Power electronics, electric drive, and hydrogen storage tanks are excluded.

${ }^{\mathrm{d}}$ The status for power plant hours is for the fuel cell system only; battery lifetime hours were not available.

\footnotetext{
${ }^{6}$ Fuel Cell Technologies Program Record \# 12012, September 12, 2012, http://www.hydrogen.energy.gov/pdfs/12012_fuel_cell_bus_targets.pdf.
} 
${ }^{\mathrm{e}}$ Multiple sequential fuel fills should be possible without an increase in fill time.

${ }^{\mathrm{f}}$ Cost targets are projected to a production volume of 400 systems per year. This production volume is assumed for analysis purposes only and does not represent an anticipated level of sales.

${ }^{g}$ AC Transit's per-bus purchase price for the ZEBA buses.

${ }^{\mathrm{h}}$ Capital costs for subsystems are not currently reported by the manufacturers.

${ }^{i}$ Excludes mid-life overhaul of the power plant.

${ }^{\mathrm{j}}$ Based on fuel economy and useful fuel tank capacity. AC Transit reports lower real-world range. 


\section{Table of Contents}

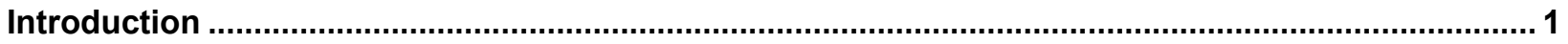

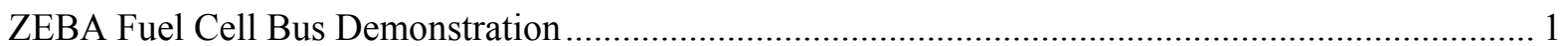

FCEB Development Process_Technology Readiness Levels .................................................... 4

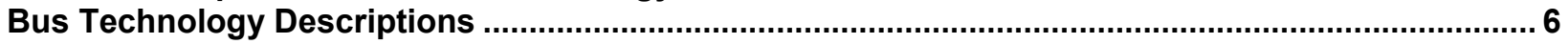

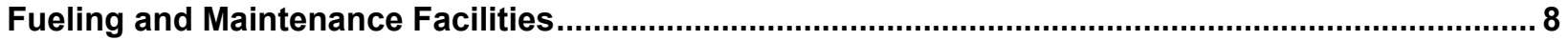

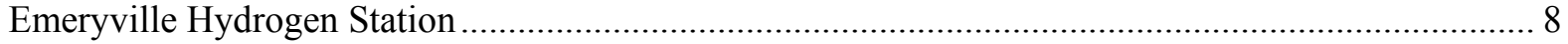

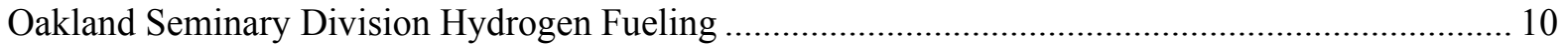

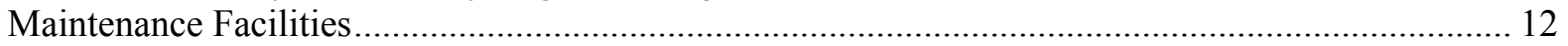

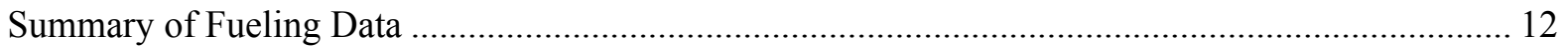

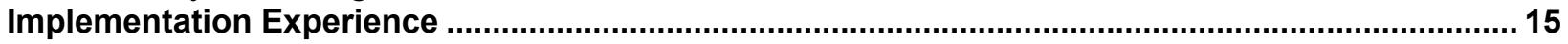

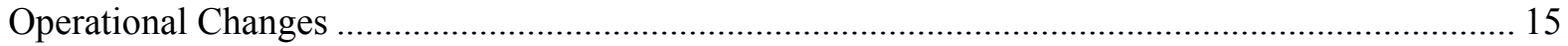

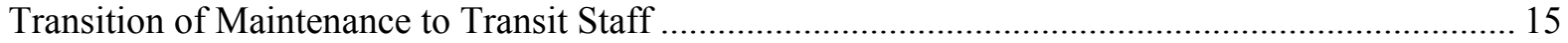

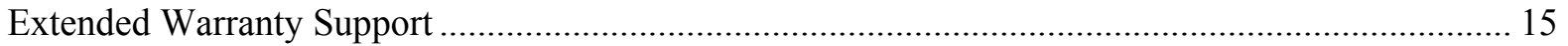

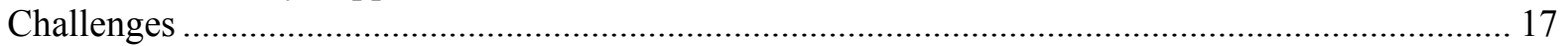

Progress Toward Meeting Technical Targets for Fuel Cell Systems ............................................. 18

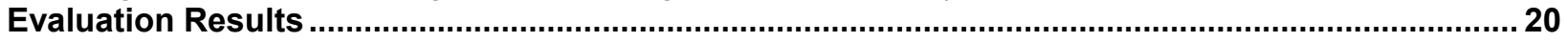

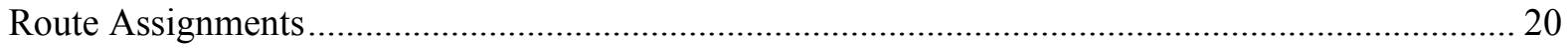

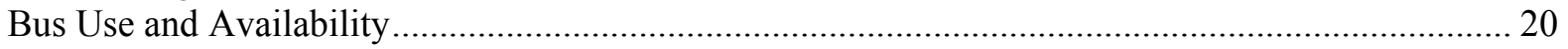

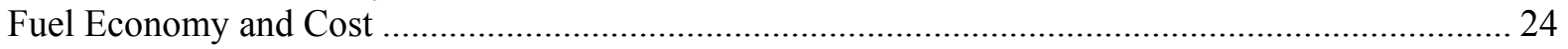

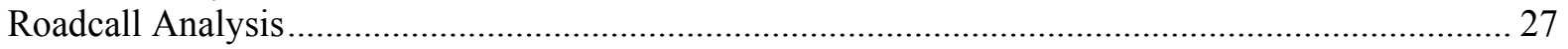

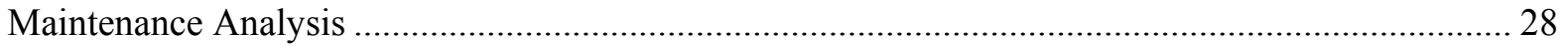

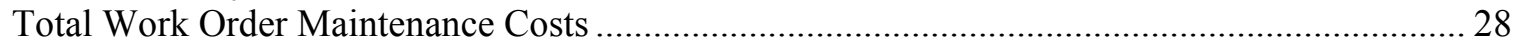

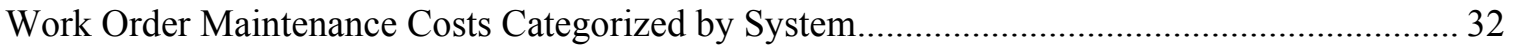

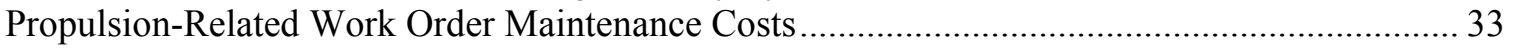

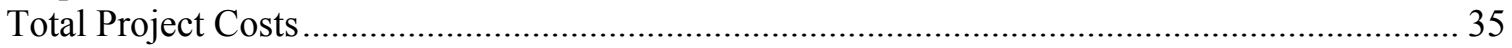

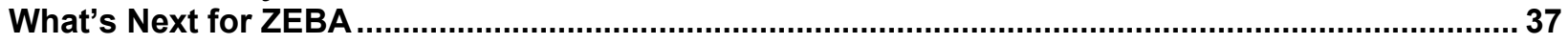

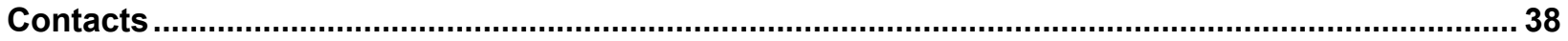

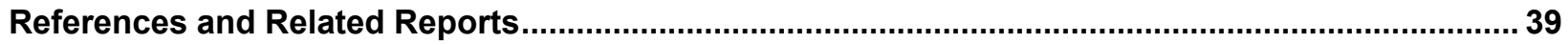

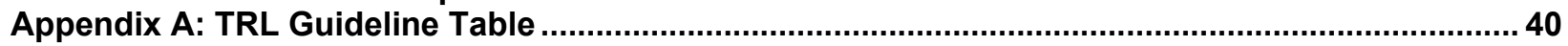

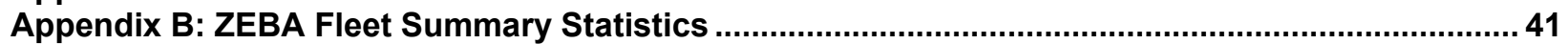

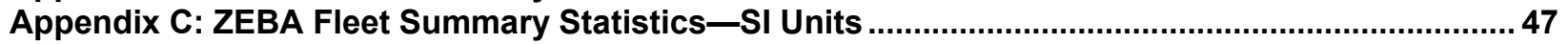

Appendix D: ZEBA Monthly Maintenance Analysis Graphs ......................................................... 48

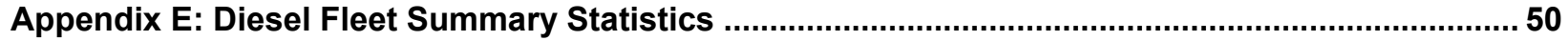

Appendix F: Diesel Fleet Summary Statistics_SI Units.......................................................... 55

Appendix G: Diesel Monthly Labor Hour Graphs ................................................................... 56 


\section{Introduction}

Alameda-Contra Costa Transit District (AC Transit) is leading a demonstration of fuel cell electric buses (FCEBs) in the San Francisco Bay Area of California. The Zero Emission Bay Area (ZEBA) demonstration includes 12 advanced-design fuel cell buses and two hydrogen fueling stations. The buses began revenue service in May 2010.This is the largest FCEB demonstration in the United States.

Several Bay Area transit agencies - including Golden Gate Transit, Santa Clara Valley Transportation Authority, and San Mateo County Transit District-participate in the ZEBA demonstration. The agencies provide funding as well as participate in data sharing discussions and training activities. Golden Gate Transit also operated one of the ZEBA buses in its service for several months to gain experience with the technology.

The ZEBA partners are collaborating with the U.S. Department of Energy (DOE) and DOE's National Renewable Energy Laboratory (NREL) to evaluate the buses in revenue service. NREL has been evaluating FCEBs under funding from DOE and the U.S. Department of Transportation's Federal Transit Administration (FTA). NREL uses a standard data-collection and analysis protocol originally developed for DOE heavy-duty vehicle evaluations. This protocol was documented in a joint evaluation plan for transit bus evaluations. ${ }^{7}$ The objectives of these evaluations are to provide comprehensive, unbiased evaluation results of fuel cell bus development and performance compared to conventional baseline vehicles. NREL published three earlier reports on this demonstration in August 2011, July 2012, and May 2014. ${ }^{8}$ This report is an update to the previous reports and focuses on data from November 2013 through December 2014.

\section{ZEBA Fuel Cell Bus Demonstration}

The California Air Resources Board's (CARB) 2000 "Fleet Rule for Transit Agencies"9 has been the primary reason for demonstrations of FCEBs in the state of California. This rule set more stringent emission standards for new urban bus engines and promoted advances in the cleanest technologies, specifically zero-emission buses (ZBus). Under the rule, agencies with more than 200 buses must include ZBuses as $15 \%$ of new bus purchases. The effective date of this purchase requirement is currently under consideration by $\mathrm{CARB}$ and the decision will take into account cost and performance data from this and other FCEB demonstrations. There were two earlygeneration ZBus demonstrations that began in the mid-2000s and paved the way for the more advanced-design buses that are in service today.

In 2006, CARB updated the transit rule and added a requirement for an advanced zero-emission bus demonstration for the larger California agencies. As a result, the five largest transit agencies in the San Francisco Bay Area formed the ZEBA demonstration group. In addition to the four previously mentioned transit agencies, San Francisco Municipal Transit Authority is a voluntary

\footnotetext{
${ }^{7}$ Fuel Cell Transit Bus Evaluations: Joint Evaluation Plan for the U.S. Department of Energy and the Federal Transit Administration, NREL/MP-560-49342-1, November 2010, http://www.nrel.gov/docs/fy11osti/49342-1.pdf.

${ }^{8}$ See the "References and Related Reports" section for links to the three previous reports on the ZEBA Demonstration.

${ }^{9}$ Fact Sheet: Fleet Rule for Transit Agencies: Urban Bus Requirements, California Air Resources Board, http://www.arb.ca.gov/msprog/bus/ub/ubfactsheet.pdf.
} 
participant because the agency already owns and operates a large fleet of zero-emission electric trolley buses. The ZEBA partners' operating areas are shown in Figure 1.

The ZEBA demonstration group is supported through funding and planning by the Metropolitan Transportation Commission, the Bay Area Air Quality Management District, CARB, the California Energy Commission, and the FTA (including early funding under the National Fuel Cell Bus Program). AC Transit was awarded a grant in the final round of the National Fuel Cell Bus Program funding. Managed through one of the non-profit consortia - the Center for Transportation and the Environment (CTE) - the \$1.8 million award provides funds to support the continued operation of the FCEB fleet.

The goals for the ZEBA demonstration include the following:

- Operating performance: Demonstrate that FCEBs can fulfill or exceed the operating requirements and standards of baseline diesel buses from the perspective of drivers and passengers (i.e., schedule adherence, vehicle handling, and passenger acceptance).

- Fleet availability: Match the "A.M. Pullout" fleet availability percentages of baseline diesel buses with a minimum fleet size of 12 buses.

- Fleet reliability: Match the miles between roadcalls (MBRC) of diesel buses for the bus as a whole and for the propulsion system category with a minimum fleet size of 12 buses.

- Fuel economy: Exceed the fuel economy of baseline diesel buses.

- Infrastructure support: Develop renewable sources of hydrogen, and demonstrate safe fueling systems and throughput (fueling speeds) equivalent to diesel fueling.

- Maintenance costs: Track labor and material costs to compare with baseline diesel buses across applicable expense categories. 


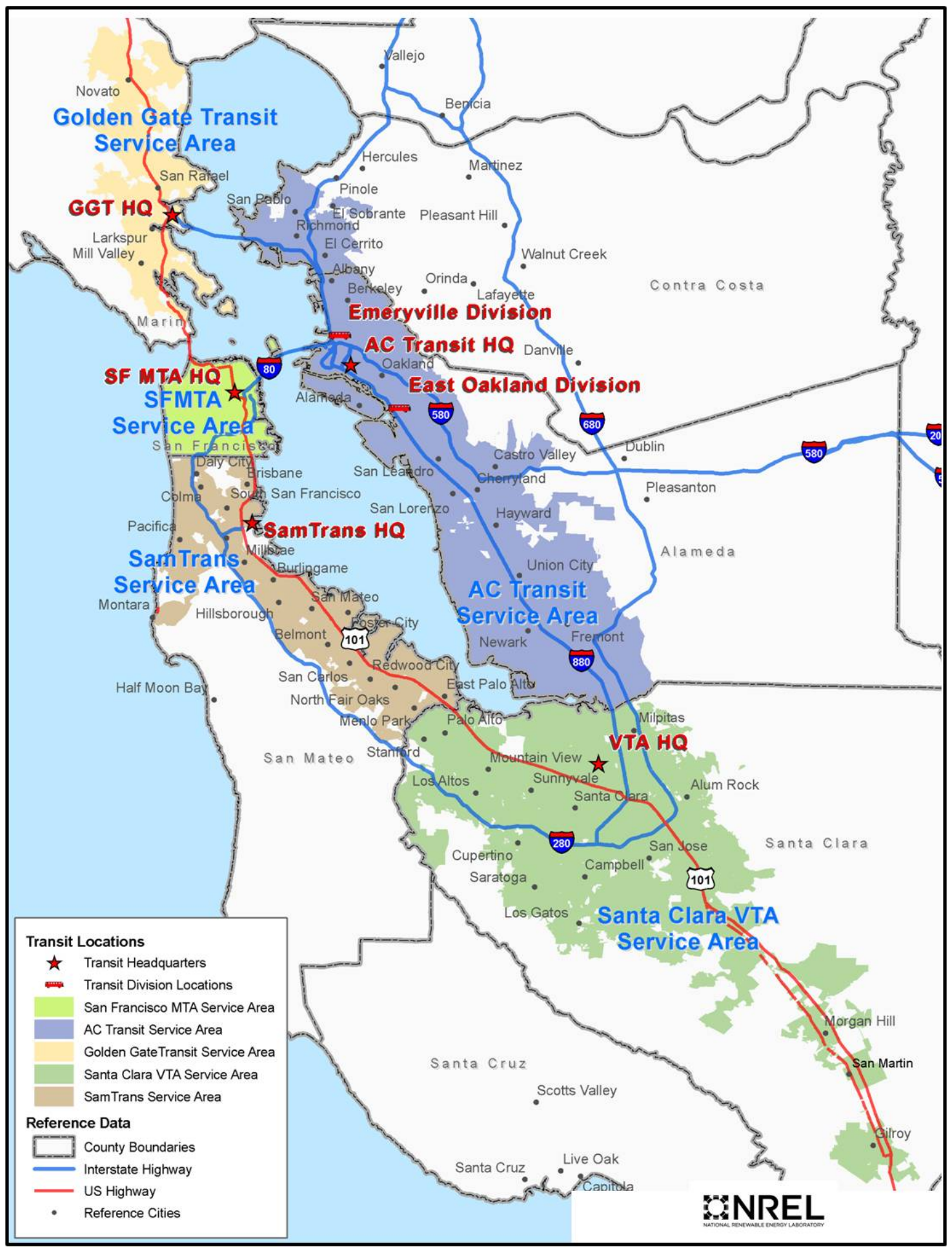

Figure 1. Map of ZEBA transit partner service areas 


\section{FCEB Development Process-Technology Readiness Levels}

In its 2012 annual FCEB status report, ${ }^{10}$ NREL introduced a guideline for assessing the technology readiness level (TRL) for FCEBs. This guideline was developed using a Technology Readiness Assessment Guide ${ }^{11}$ published by DOE in September 2011. Figure 2 provides a graphic representation of this process. (Appendix A provides the TRL guideline table tailored for FCEB commercialization.) The guideline considers the FCEB as a whole and does not account for differing TRLs for separate components or sub-systems. Some sub-systems may include offthe-shelf components that are considered commercial, while other sub-systems may feature newly designed components at an earlier TRL.

\section{Commercialization Process}

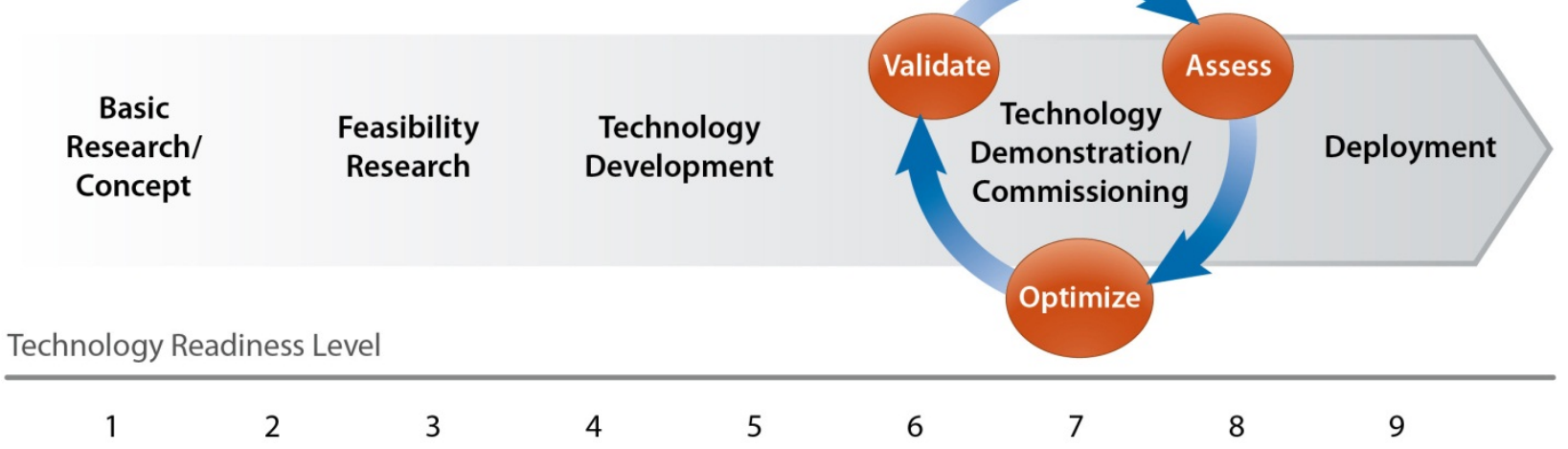

Figure 2. Graphic representation of the commercialization process developed for FCEBs

FCEB development is currently in the technology demonstration/commissioning phase that includes TRLs 6 through 8 . This phase begins the iterative process to validate the design, analyze the results, and reconfigure or optimize the design as needed. The manufacturer typically works with a transit agency partner to conduct in-service tests on the bus. Updates to the design are made based on the performance results, and the buses go back into demonstration and through the cycle until the design meets the performance requirements. This can be a time-consuming process as manufacturers work through technical difficulties.

NREL considers the ZEBA buses to be at TRL 7 because the design of the bus was led by manufacturers experienced with FCEB development and the deployment includes the 12-bus ZEBA fleet. These buses represent a full-scale validation in a relevant environment. At this point in the development, FCEBs are not commercial products. The manufacturers' goals for the demonstration are to verify that the FCEB performance meets the technical targets and identify any issues that need to be resolved. The current costs for FCEB technology - both capital and operating costs - are still much higher than that of conventional diesel technology. This is expected considering diesel is a very mature technology (TRL 9) and FCEBs are still in the development stage. Once an advanced technology, such as FCEBs, meets the performance

\footnotetext{
${ }^{10}$ Fuel Cell Buses in U.S. Transit Fleets: Current Status 2012, NREL/TP-5600-56406, http://www.nrel.gov/docs/fy13osti/56406.pdf.

${ }^{11}$ DOE Technology Readiness Assessment Guide, G 143.3-4a, https://www.directives.doe.gov/directives/0413.3-EGuide-04a/view.
} 
targets, the industry can work to reduce costs. This was the case with both compressed natural gas and diesel-hybrid bus technologies when they were first developed.

NREL's goal in evaluating FCEBs is to document the performance and track progress over time toward meeting the technical targets. NREL collects data on conventional buses at each demonstration site for a baseline comparison. This is important primarily because fuel economy is highly dependent on duty cycle, but also because maintenance practices can be different from site to site. The best comparisons need to include buses operated in similar service at the same operating division. The most accurate comparison would be between buses of the same manufacturer, model, production year, and mileage. In that case, the only difference between the FCEB and baseline buses would be the propulsion system. This type of baseline comparison is not always possible.

NREL collects data on two groups of baseline buses at AC Transit. The first group consists of four Van Hool diesel buses that are the same model as the FCEBs. These buses are the best physical match for the FCEBs; however, they are slightly older, have accumulated 4 times more miles than the FCEBs, and are no longer under warranty. These buses have reached mid-life, and maintenance records have begun to show increased cost typical of this period. The second group consists of ten 40-foot Gillig buses purchased in early 2013. These Gillig buses provide a comparison of the newest diesel technology to the FCEBs. The Gillig buses are younger; however, the mileage of each bus is closer to that of the FCEBs for the evaluation period presented in this report. 


\section{Bus Technology Descriptions}

Table 1 provides bus system descriptions for the fuel cell and diesel buses that were studied in this evaluation. The FCEBs in service at AC Transit (Figure 3) are 40-foot, low-floor buses built by Van Hool with a hybrid electric propulsion system that includes a US Hybrid fuel cell power system. The Van Hool diesel buses have Cummins engines with a diesel oxidation catalyst. The Gillig buses have Cummins engines that meet 2010 EPA emissions standards using a diesel particulate filter and selective catalytic reduction. Figure 4 shows one of AC Transit's Van Hool diesel buses and Figure 5 shows one of the new Gillig diesel buses.

Table 1. Fuel Cell and Diesel Bus System Descriptions

\begin{tabular}{|c|c|c|c|}
\hline Vehicle System & FCEB & Diesel Van Hool & Diesel Gillig \\
\hline Number of buses & 12 & 3 & 10 \\
\hline Bus manufacturer/model & $\begin{array}{c}\text { Van Hool A300L FC low } \\
\text { floor }\end{array}$ & $\begin{array}{c}\text { Van Hool A300L low } \\
\text { floor }\end{array}$ & Gillig low floor \\
\hline Model year & 2010 & 2009 & 2013 \\
\hline Length/width/height & $40 \mathrm{ft} / 102 \mathrm{in} . / 136 \mathrm{in}$. & $40 \mathrm{ft} / 102 \mathrm{in.} / 121 \mathrm{in}$. & $40 \mathrm{ft} / 102 \mathrm{in.} / 122 \mathrm{in.}$ \\
\hline GVWR/curb weight & $39,350 \mathrm{lb} / 31,400 \mathrm{lb}$ & $40,800 \mathrm{lb} / 27,800 \mathrm{lb}$ & $39,600 \mathrm{lb}$ \\
\hline Wheelbase & 269 in. & 278 in. & 279 in. \\
\hline Passenger capacity & $\begin{array}{l}33 \text { seated or } 29 \text { seated } \\
\text { plus } 2 \text { wheelchairs }\end{array}$ & $\begin{array}{l}31 \text { seated or } 28 \text { seated } \\
\text { plus } 2 \text { wheelchairs }\end{array}$ & $\begin{array}{c}37 \text { seated or } 29 \text { seated } \\
\text { plus } 2 \text { wheelchairs }\end{array}$ \\
\hline Engine manufacturer/model & $\begin{array}{l}\text { US Hybrid fuel cell } \\
\text { power system }\end{array}$ & Cummins ISL, 8.9L & Cummins ISL, 8.9L \\
\hline Rated power & $\begin{array}{c}\text { Fuel cell power system: } \\
120 \mathrm{~kW} \\
\end{array}$ & 280 hp @ 2,200 rpm & 280 hp @ 2,200 rpm \\
\hline Accessories & Electrical & Mechanical & Mechanical \\
\hline Emissions equipment & None & $\begin{array}{l}\text { Diesel oxidation } \\
\text { catalyst }\end{array}$ & $\begin{array}{c}\text { Diesel particulate filter } \\
\text { and selective catalytic } \\
\text { reduction }\end{array}$ \\
\hline Transmission/retarder & $\begin{array}{l}\text { Seico brake resistors } \\
\text { regenerative braking }\end{array}$ & $\begin{array}{c}\text { Voith } \\
\text { integrated retarder }\end{array}$ & Allison \\
\hline Fuel capacity & $40 \mathrm{~kg}$ hydrogen & $92 \mathrm{gal}$ & 120 gal \\
\hline Bus purchase cost & $\$ 2.5$ million & $\$ 323,000$ & $\$ 413,826$ \\
\hline
\end{tabular}

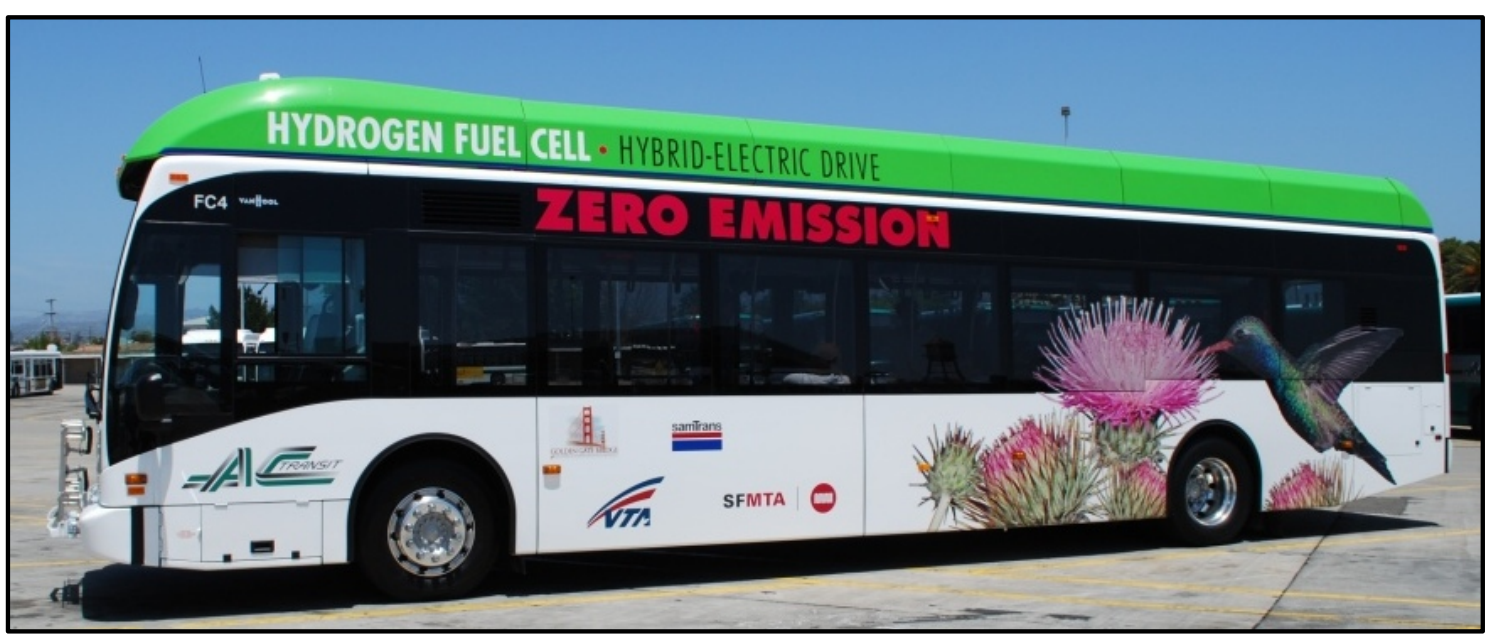

Figure 3. AC Transit fuel cell electric bus 


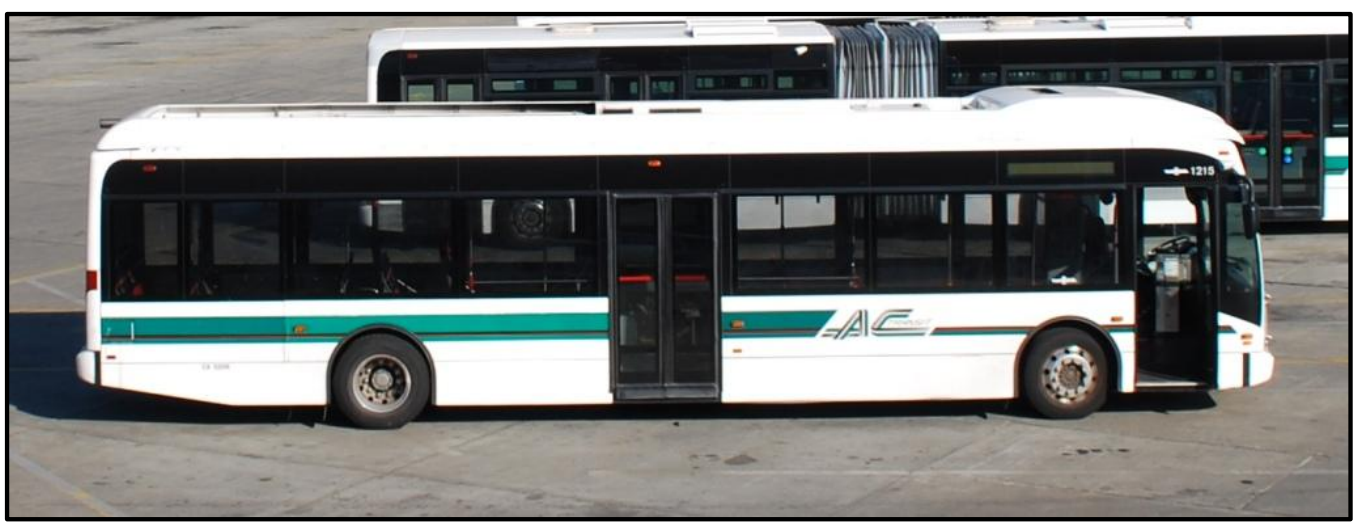

Figure 4. AC Transit Van Hool diesel bus at Emeryville Division

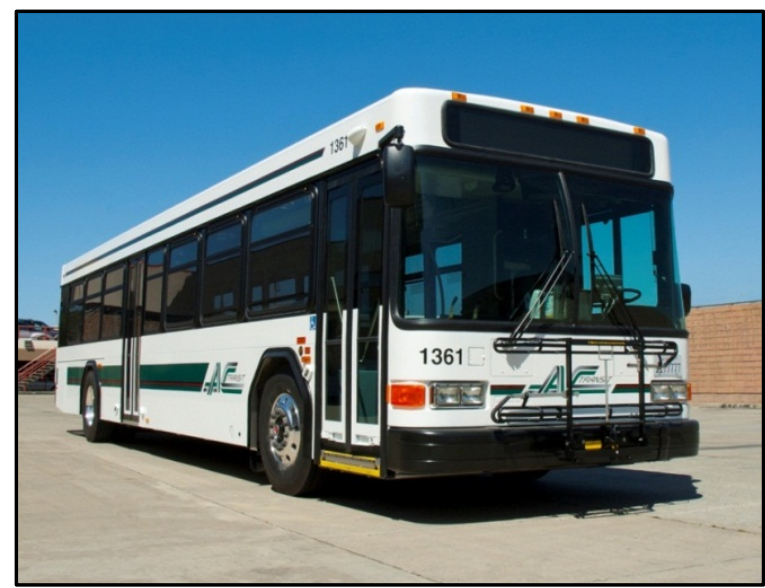

Figure 5. AC Transit Gillig diesel bus. Photo courtesy of AC Transit

Table 2 provides a description of some of the electric propulsion systems for the fuel cell buses. The diesel baseline buses are not hybrids and do not have regenerative braking or energy storage for the drive system. The FCEBs have a fuel cell dominant hybrid electric propulsion system in a series configuration. Van Hool fully integrated the hybrid design using a Siemens ELFA 2 hybrid system; US Hybrid fuel cell power system; and an advanced lithium-based energy storage system by EnerDel.

Table 2. Additional Electric Propulsion System Descriptions

\begin{tabular}{|l|l|}
\hline Propulsion Systems & \multicolumn{1}{c|}{ Fuel Cell Bus } \\
\hline Integrator & Van Hool \\
\hline Hybrid type & Series, charge sustaining \\
\hline Drive system & Siemens ELFA \\
\hline Propulsion motor & 2-AC induction, 85 kW each \\
\hline & Battery: EnerDel, lithium ion \\
Energy storage & $\begin{array}{l}\text { Rated energy: 21 kWh } \\
\text { Rated capacity: 29 Ah } \\
\text { Rated power: 76 to 125 kW }\end{array}$ \\
\hline Fuel storage & $\begin{array}{l}\text { Eight roof mounted, Luxfer, type 3 } \\
\text { tanks; 5,000 psi rated }\end{array}$ \\
\hline Regenerative braking & Yes \\
\hline
\end{tabular}




\section{Fueling and Maintenance Facilities}

To supply hydrogen for the ZEBA demonstration, AC Transit constructed two hydrogen stations: one at the Emeryville Division and another at the Oakland Division. For the earlier FCEB demonstration, AC Transit modified a maintenance bay in the Oakland garage to allow safe maintenance of hydrogen-fueled buses. The agency is in the process of upgrading the garage at Emeryville to include a similar hydrogen-ready bay for maintenance. This section describes the stations at Emeryville and Oakland, outlines plans for the Emeryville maintenance bay upgrade, and provides a summary of fueling data from September 2011 through December 2014.

\section{Emeryville Hydrogen Station}

AC Transit's Emeryville hydrogen station, built by Linde LLC, was completed in July 2011 and fully commissioned by the end of August 2011. This station, shown in Figure 6, is a combined facility for light-duty fuel cell electric vehicles (FCEV) and FCEBs. AC Transit reports that engineering and construction costs for the station were $\$ 10$ million. Funding from the state of California made the light-duty FCEV fueling access possible. Dispensers are available to fuel at 350 and 700 bar pressure.

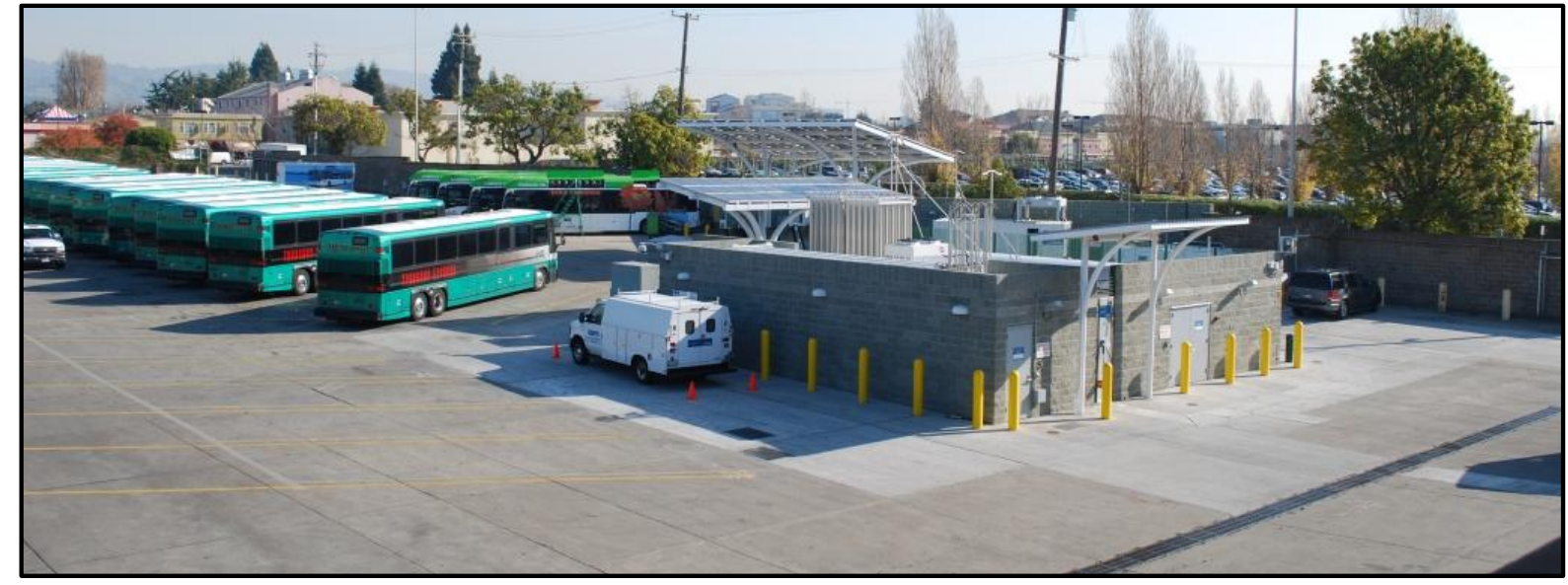

Figure 6. The Linde hydrogen station at AC Transit's Emeryville Division

Figure 7 provides a simple block diagram of the station and primary components. Hydrogen is provided from two sources: liquid hydrogen delivery and a solar-powered electrolyzer. Hydrogen from both sources feeds into high-pressure gaseous storage tubes for fueling buses and autos. The electrolyzer is capable of producing $65 \mathrm{~kg}$ of hydrogen per day. When combined with the delivered liquid hydrogen, the station has the capacity to dispense up to $600 \mathrm{~kg}$ of hydrogen per day.

The station uses two compressors: one is a high-pressure mechanical compressor and the other is an ionic compressor. The mechanical compressor (MF-90) handles the FCEV side of the station and is capable of filling at both 350 and 700 bar. The MF-90 boosts the pressure to 700 bar for the FCEVs that operate at the higher pressure. The station can fully fuel a light-duty vehicle in 3 to 5 minutes depending on vehicle tank capacity. 


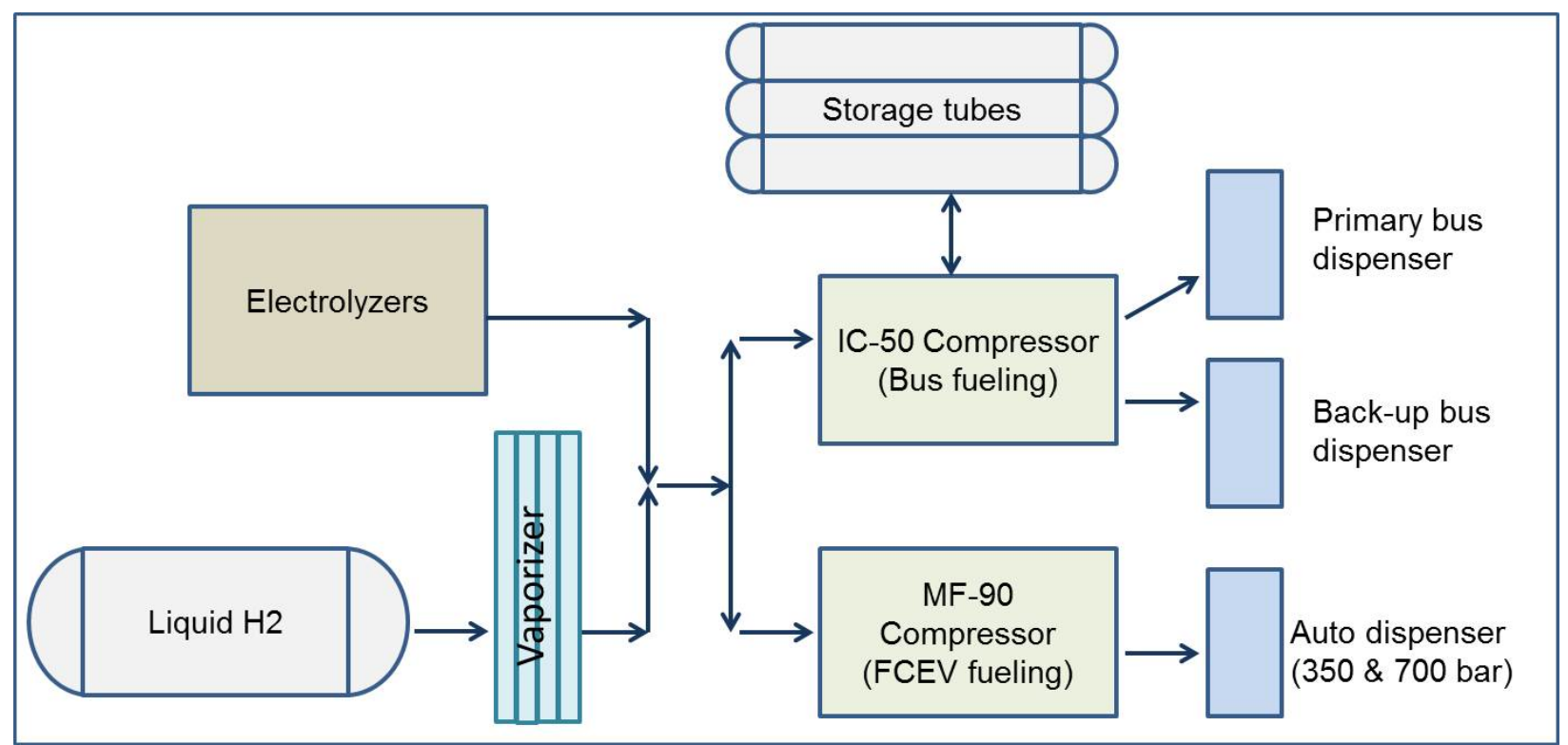

Figure 7. Block diagram of the Emeryville station

The bus fueling side of the station is handled by Linde's ionic compressor (IC-50). The IC-50 uses a proprietary ionic liquid in place of a mechanical piston. The buses can be fueled quickly$30 \mathrm{~kg}$ in about 6 minutes. Figure 8 shows the bus fueling area and a picture of the primary bus dispenser. The station also has a back-up dispenser for the buses in case there are issues with the primary fueling dispenser. AC Transit has a maintenance contract with Linde for 3 years with options for extension. The annual cost for this maintenance and service agreement is approximately $\$ 142,000$.

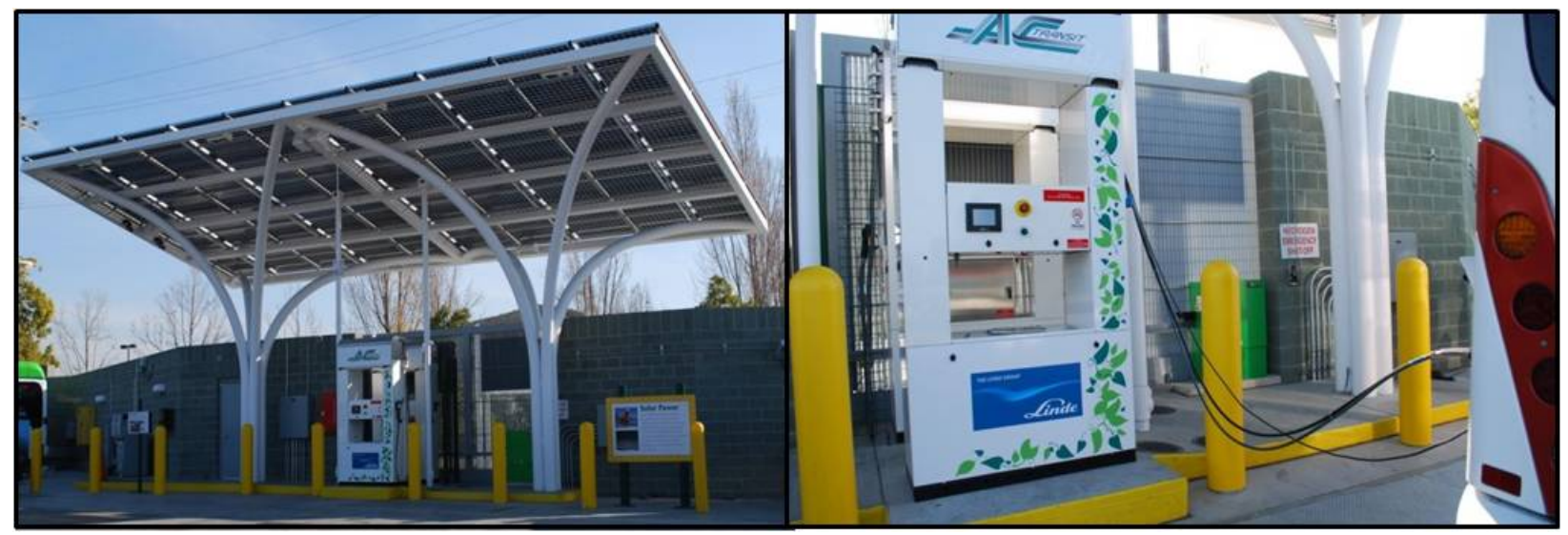

Figure 8. Bus fueling at the Emeryville hydrogen station: fueling area (left) and close-up of the bus dispenser (right) 


\section{Oakland Seminary Division Hydrogen Fueling}

AC Transit also contracted with Linde for the newly completed station at the Seminary Division in Oakland. This station is similar in design to the one at Emeryville. The primary differences are as follows:

- The bus dispensers are installed in-line with the diesel fueling island.

- There is no public access for light-duty FCEV fueling because the station is at the back of the property.

- Hydrogen is available at 350 bar pressure only.

- Once installed, the on-site electrolyzer will be powered by a solid oxide fuel cell fueled with directed biogas. ${ }^{12}$

The Oakland station construction was completed in late 2014 and AC Transit commissioned the station in December. Figure 9 shows a simple block diagram of the primary components of the station. Currently the station is supplied with liquid hydrogen delivery and storage. Eventually, an electrolyzer will be installed to supplement the hydrogen supply. Figure 10 shows the station equipment installed at the Oakland Division as of February 2015.

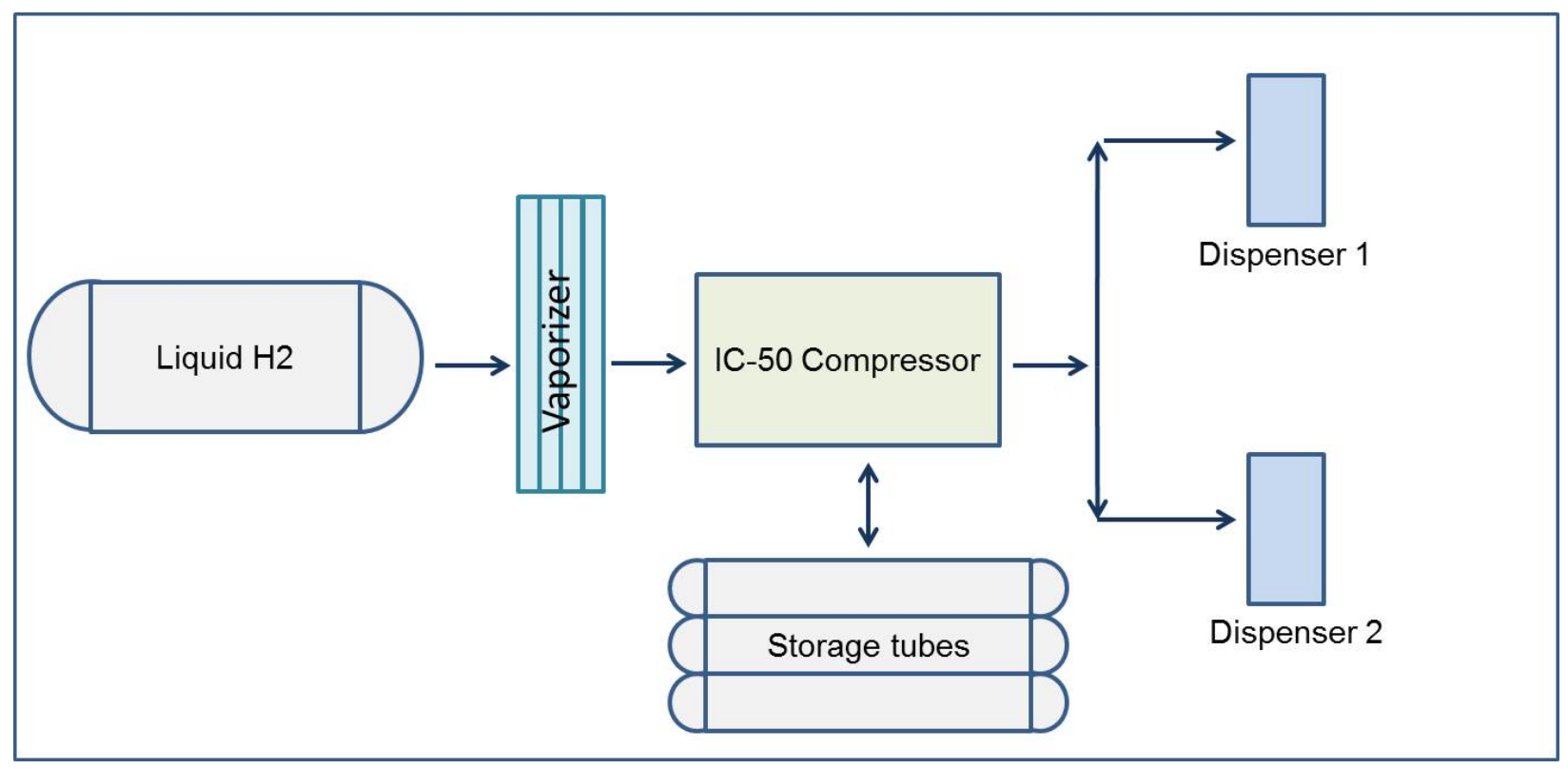

Figure 9. Block diagram of the Oakland station (as of February 2015)

\footnotetext{
${ }^{12}$ Directed biogas implies a process of injecting purified biomethane (methane/natural gas developed from decaying organic matter) into the natural gas pipeline. Designated customers of the biomethane do not use the identical biomethane but can take credit for using the biomethane when using natural gas from the pipeline.
} 


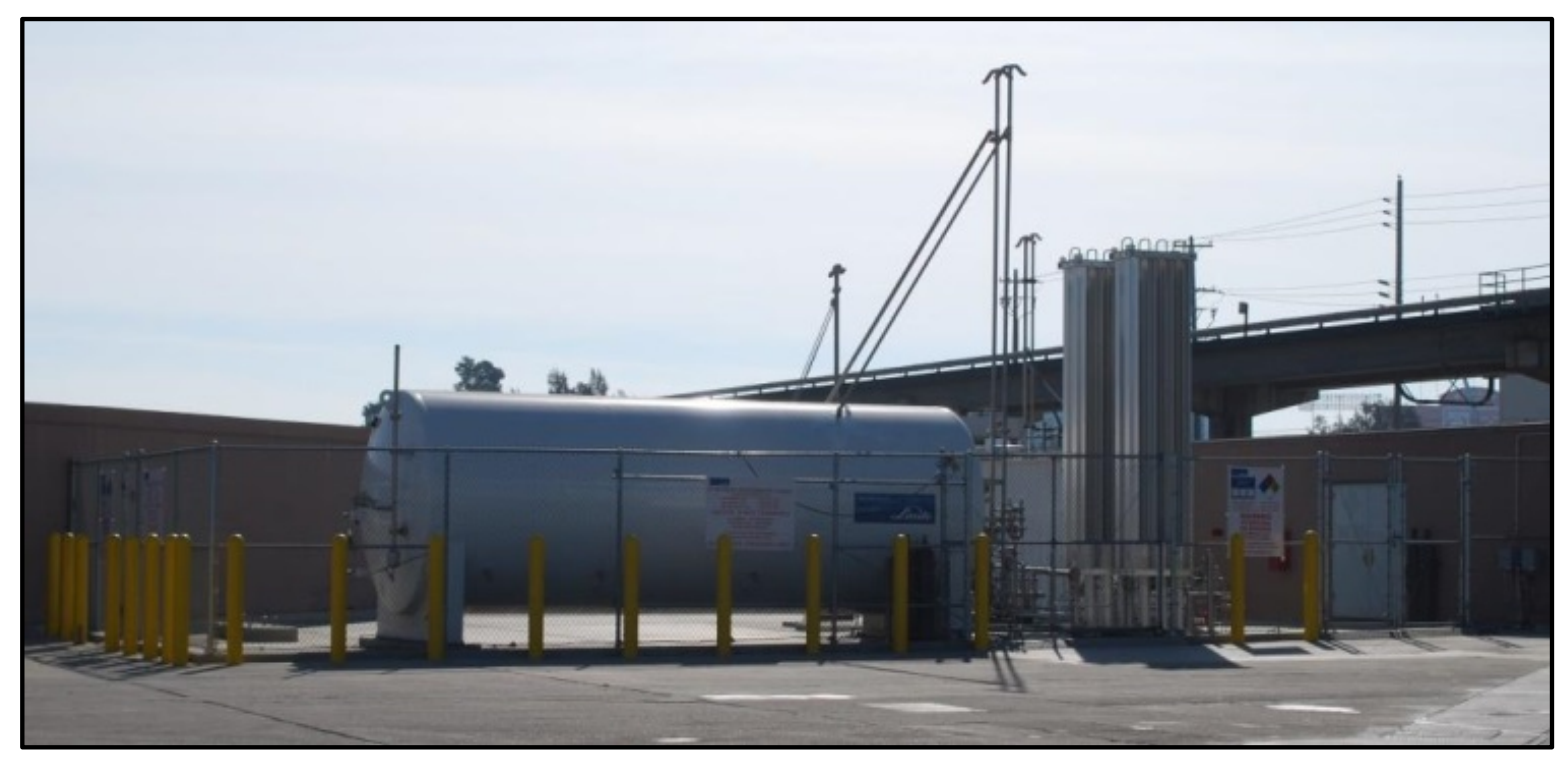

Figure 10. Linde hydrogen station at the Oakland Division

The Oakland station includes one compressor for fueling the buses - a Linde IC-50 ionic compressor. The two dispensers are installed in-line with the diesel fuel island. This is an important step in integrating this new technology into standard transit practice. The ZEBA buses are fueled and prepped for the next day's service along with all of the diesel buses at the depot. The station can handle back-to-back fuelings, but it does not allow simultaneous fueling from the two dispensers. Figure 11 shows the modified fueling island and extended canopy. Figure 12 shows an up-close picture of one of the dispensers.

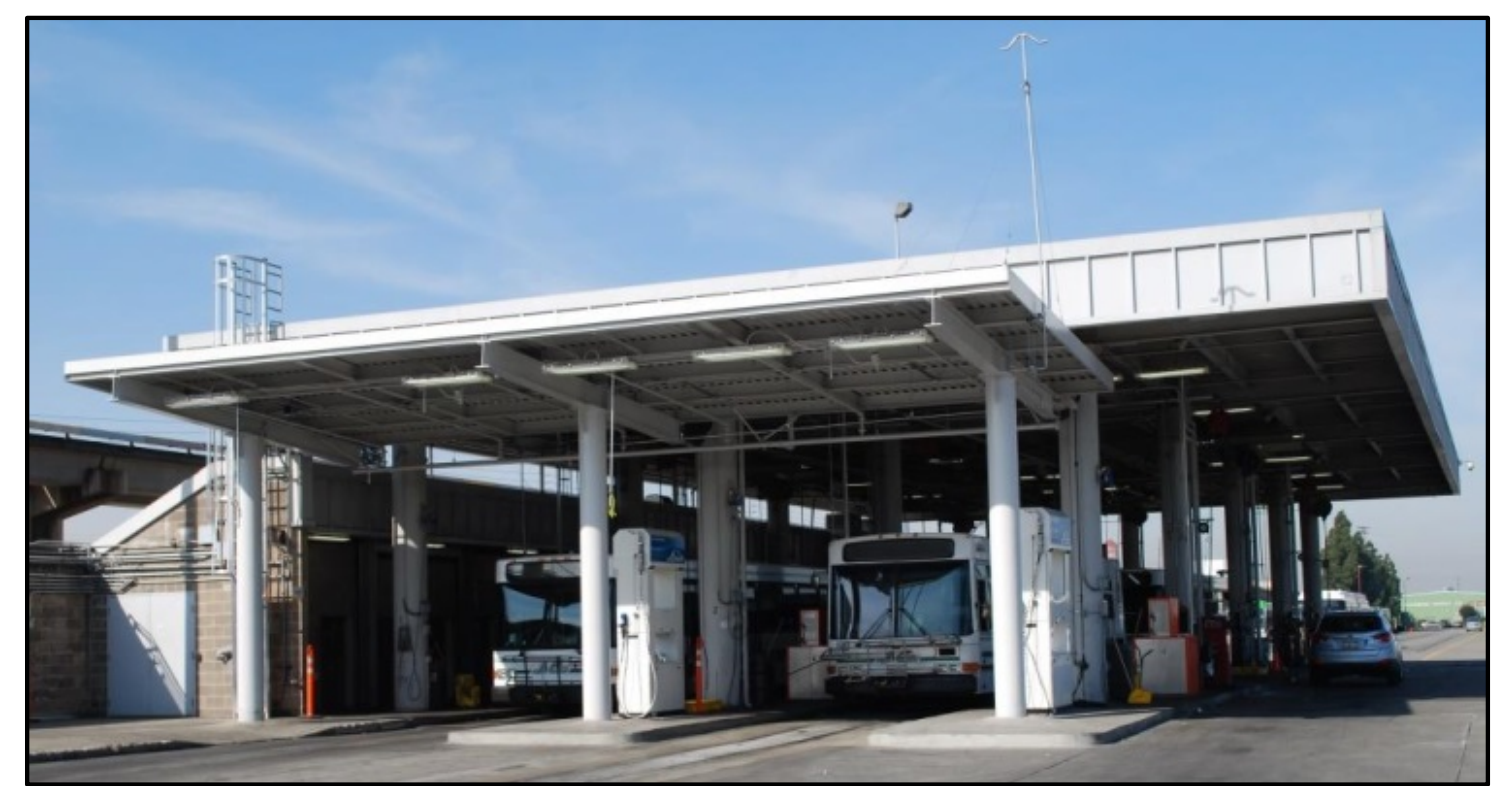

Figure 11. Hydrogen dispensers in-line with the diesel fueling island 


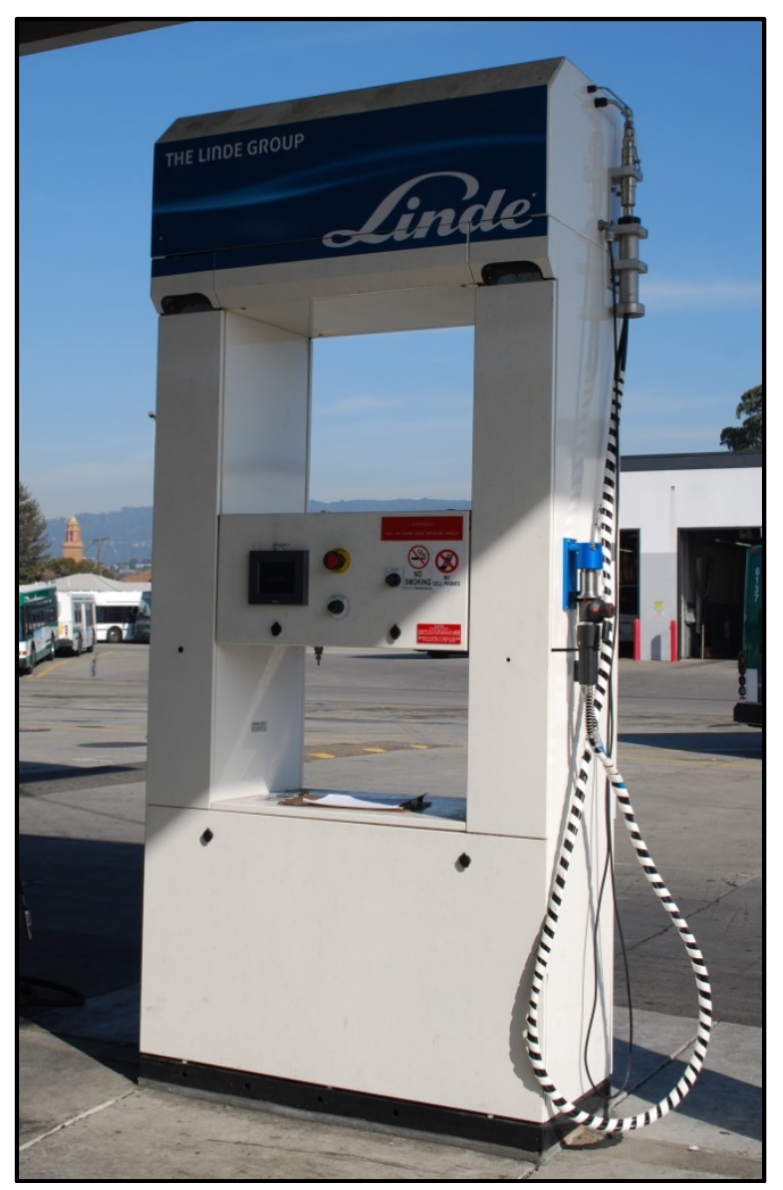

Figure 12. Hydrogen dispenser at the Oakland station

\section{Maintenance Facilities}

In 2005, AC Transit converted one of the maintenance bays at the Oakland Seminary Division to accommodate hydrogen-fueled buses for the earlier demonstration. This bay is available for the FCEBs. While the fleet was operated out of the Emeryville Division, AC Transit maintenance staff had to shuttle the buses between the divisions, which resulted in additional labor charges. The agency has begun an upgrade at the Emeryville Division to convert two bays for safe maintenance of hydrogen-fueled buses. Once this modification is complete, all maintenance for the buses stationed at Emeryville will be handled there without the need to shuttle the buses between depots. AC Transit reports that the estimated cost to upgrade a maintenance bay is between $\$ 300,000$ and $\$ 350,000$.

\section{Summary of Fueling Data}

The ZEBA buses have been fueled at the Emeryville station since it was commissioned in August 2011. AC Transit began using the Oakland station in December 2014. Figure 13 shows the average daily hydrogen dispensed (for days when hydrogen was dispensed; zero-use days were excluded) by month for the data period beginning in March 2013 through December 2014. The graph includes fuel dispensed from both stations. During this period, the buses were fueled 5,132 times for a total of $99,400 \mathrm{~kg}$ of hydrogen. The average amount per fueling was $19.4 \mathrm{~kg}$. Figure 14 tracks the total hydrogen dispensed into the buses each month from March 2013 
through December 2014. Figure 15 shows the cumulative hydrogen dispensed into the buses since the beginning of the demonstration. Nearly $140,000 \mathrm{~kg}$ of hydrogen has been dispensed into the buses since they first began service.

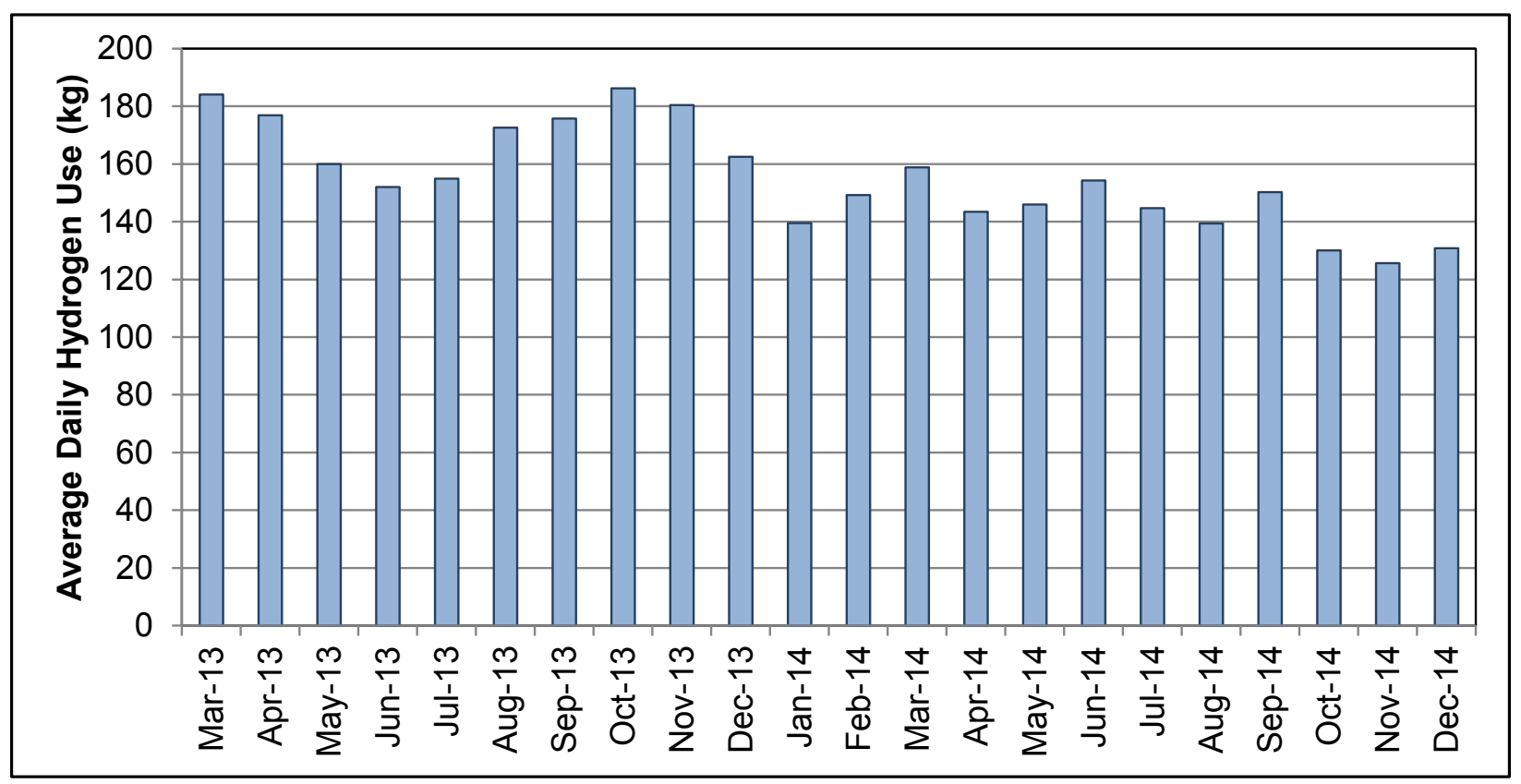

Figure 13. Average hydrogen dispensed per day at AC Transit's hydrogen stations (excluding $0 \mathrm{~kg}$ days)

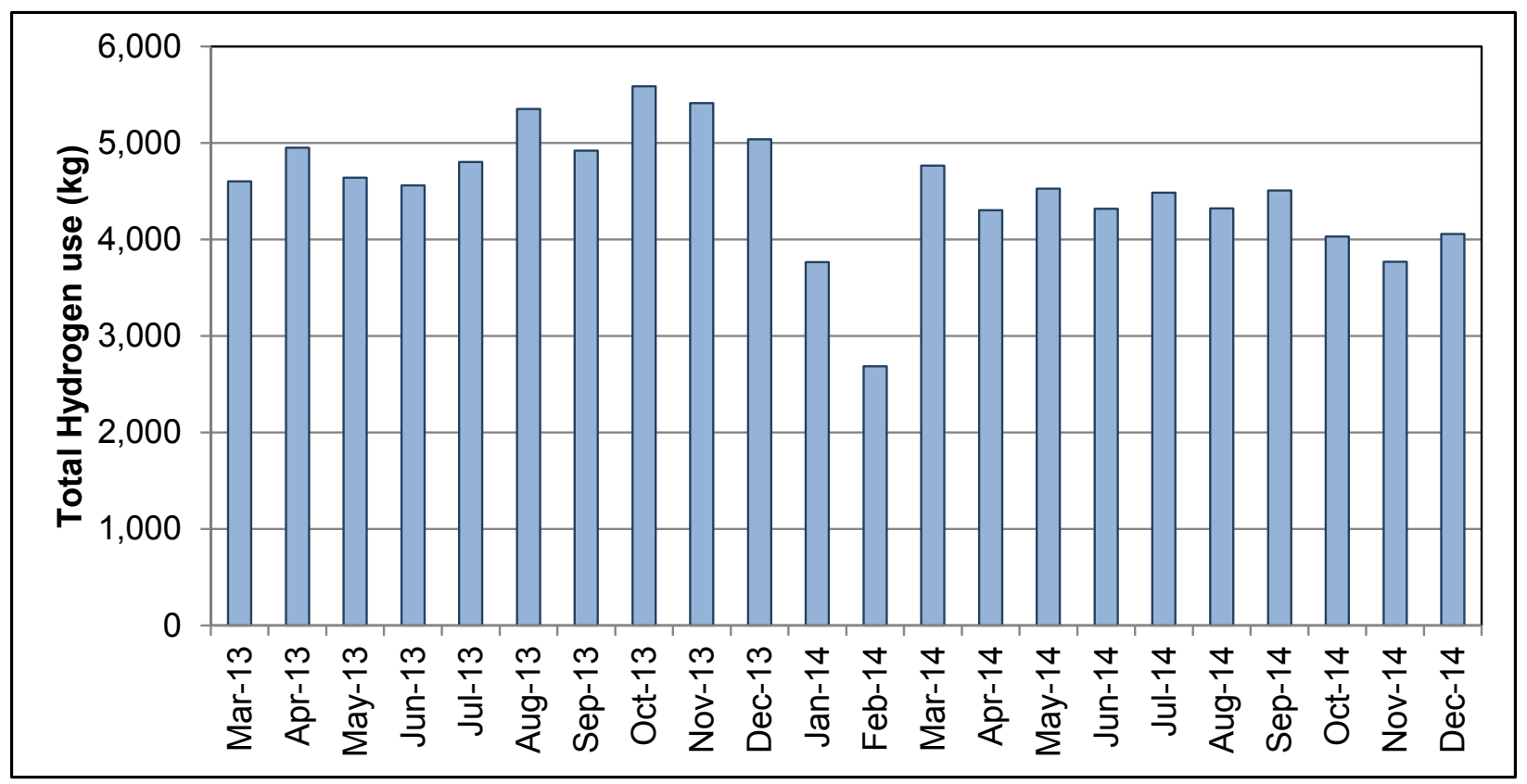

Figure 14. Total hydrogen dispensed per month at AC Transit's hydrogen stations 


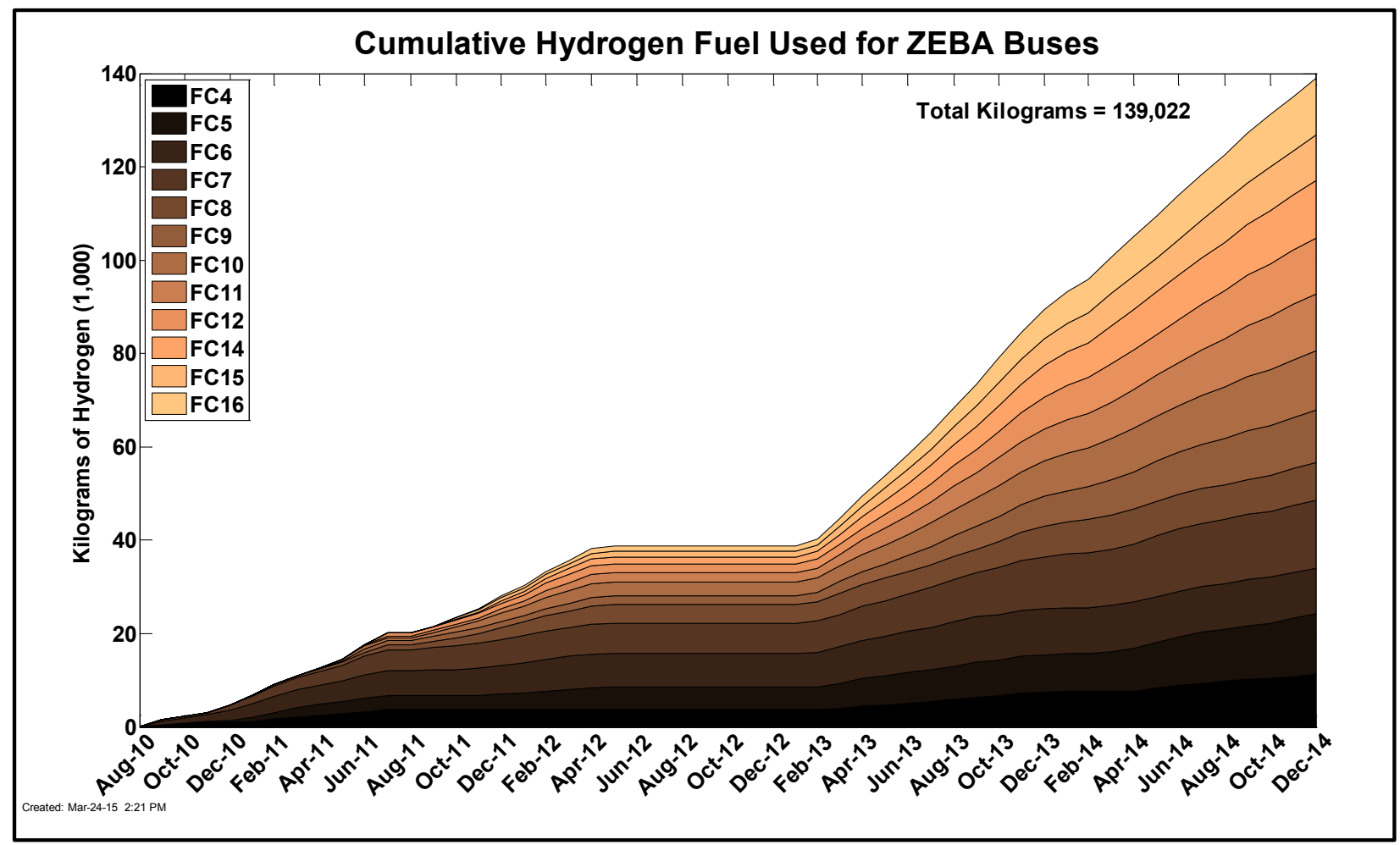

Figure 15. Cumulative hydrogen dispensed into the buses through December $2014^{13}$

\footnotetext{
${ }^{13}$ The Emeryville station was out of service from May 2012 through late January 2013; therefore no fuel was
} dispensed into the buses during that time. The downtime was explained in the previous report. 


\section{Implementation Experience}

This section focuses on the project partners' experiences in implementing FCEBs into the fleet including the achievements and challenges encountered since the last report. Project partners include AC Transit and the manufacturers. Over the last year, AC transit has made several changes to the demonstration program to further test the capabilities of the technology.

\section{Operational Changes}

The FCEB fleet was operated out of the Emeryville Division from August 2011 until November 2014. The new hydrogen station at the Oakland Division was completed in November 2014 and fully commissioned in December 2014. At that time, four buses were transferred from the Emeryville Division to the Oakland Division. Eventually the agency plans to split the fleet to operate eight FCEBs out of Oakland and four out of Emeryville. AC Transit reports that shifting some of the FCEBs back to the Oakland Division went well with very few issues. There were some minor problems with drivers not being familiar with the start-up and shut-down sequence for the buses. That has been addressed with driver training. The agency also plans to add decals to the buses with step-by-step instructions as a reminder for drivers who may not drive the FCEBs every day.

AC Transit continues to work toward full integration of the FCEBs into the standard operation of the fleet. The ultimate goal is to treat the FCEBs the same as the conventional diesel buses. The agency is now allowing the buses to be assigned to any route that 40 -foot buses operate on with the exception of commuter routes. All drivers at both depots have been trained to operate the buses to facilitate this random dispatch for the buses.

\section{Transition of Maintenance to Transit Staff}

The transition of knowledge from the manufacturers to the transit staff is essential to commercializing the technology. During the early stages of the demonstration, an on-site engineer from the fuel cell manufacturer handled preventive maintenance and repair of the more advanced components. This has changed over the last year. AC Transit staff has received training and taken on all preventive maintenance and repair work on the fuel cell buses. AC Transit has assigned a dedicated supervisor and mechanic at each depot to lead the work on the FCEBs. These employees handle the training and bring in other staff as needed. US Hybrid has developed the service and maintenance manual, wireless diagnostic tools, and resources that the agency can use to help troubleshoot issues and perform the repairs on-site. Most manufacturer support will be provided through remote diagnostics.

\section{Extended Warranty Support}

The ZEBA buses were delivered beginning in 2010 and are now past the original manufacturer warranty period. AC Transit was awarded a $\$ 1.8$ million grant in the final round of the National Fuel Cell Bus Program funding to support the continued operation of the FCEB fleet. The grant is managed through CTE. Over the last year, CTE has helped AC Transit negotiate agreements with US Hybrid and EnerDel for extended warranty support. AC Transit set up purchase orders with Siemens, VanHool, and Luxfer for parts as needed. 
US Hybrid support agreement - AC Transit has entered into a 3-year agreement with US Hybrid for support on the fuel cell power plants (FCPPs). The total cost for the agreement is $\$ 499,971$. US Hybrid provides on-site advisor support that includes monthly site visits to evaluate the FCPPs. During these visits, US Hybrid works with AC Transit staff to inspect and complete any work needed on the FCPPs. The agreement includes four primary tasks:

1. Diagnostics support-remote diagnostics and assistance as needed for issues relating to the FCPPs. US Hybrid developed a troubleshooting manual that includes a diagnostic flow chart to aid AC Transit staff in diagnosing any issues. This manual includes step-bystep instructions on how to retrieve trouble codes, identify failure reasons, and repair the issue. US Hybrid has equipped all of the buses with wireless modules that enable remote access to on-board FCPP diagnostics and data collection. These data are accessible by US Hybrid and AC Transit staff to aid in troubleshooting any issues.

2. Training - US Hybrid will provide two formal training sessions on FCPP diagnostics and safety training. US Hybrid has also provided two laptops with diagnostic software and interconnects to $\mathrm{AC}$ Transit to use during the duration of the agreement.

3. Parts and materials - US Hybrid will provide all balance of plant replacement parts needed to maintain each FCPP for revenue service. This includes maintaining an inventory of spare parts at the transit agency. The agreement does not cover the cost of replacing a fuel cell stack if that is needed.

4. Preventive maintenance-AC Transit is responsible for regular preventive maintenance inspections on the FCPPs. US Hybrid provided a schedule for preventive maintenance and trained AC Transit staff to perform tasks.

EnerDel support agreement - AC Transit has a 3-year agreement with EnerDel that covers quarterly field repairs for 13 hybrid system battery packs, on-site visits as needed, and nonwarranty repairs or mechanical damage. EnerDel will conduct diagnostics to determine any issues, replace components, and test to verify repairs were successful. The total cost for this agreement is $\$ 690,000$.

The warranty agreement includes reconditioning of each battery pack beginning in the second quarter of 2014 through the second quarter of 2015. The packs are shipped to EnerDel where they are disassembled and the sub-components are reconditioned and tested. Any units that do not meet specifications are replaced. The fully assembled and tested pack is shipped back to AC Transit to be reinstalled into a bus.

The agreement also includes remanufacturing of the battery packs from the third quarter of 2015 through the fourth quarter of 2016. The remanufacturing process includes replacing all of the cells in the pack, reassembly, and testing. To minimize downtime for the buses, EnerDel has provided a spare battery pack. This pack is owned by EnerDel with all service and maintenance covered at the company's expense. 


\section{Challenges}

Advanced technology demonstrations typically experience challenges and issues that need to be resolved. A few of the issues and status of resolution are provided here.

- Maintenance training and learning curve - To fully integrate an advanced technology into a fleet, a transit agency needs to train all maintenance staff to handle scheduled and unscheduled work on the buses. AC Transit is making major progress in transitioning this work to agency staff. Training all maintenance staff is easier to justify as fleet sizes increase. Mechanics become more comfortable with new technology and procedures with time. Troubleshooting during this stage of development can be challenging, and it is often labor intensive as staff go through the learning curve. This added labor cost typically increases after transit staff takes over maintenance work but drops over time as they become more familiar with the technology.

- Parts supply - AC Transit has had issues in the past with bus components that have a long lead time for delivery, in some cases because they come from outside the United States. These components were not typically stocked and were only ordered when needed. This has changed over time as the project partners have learned what should be kept on hand. Although the parts supply issues have improved, they have not yet been completely resolved. The industry needs to further develop a robust supply chain for these advanced components for FCEBs (as well as other electric drive buses).

- Bus range - AC Transit has had issues with real-world bus range being lower than expected. The agency has reported multiple roadcalls when the low fuel light comes on while an FCEB is in service. This indicator is the same as the low fuel light on many cars and doesn't necessarily mean the bus is out of fuel. In some cases, the roadcalls are because some drivers have expressed that they are uncomfortable when the low fuel light comes on. AC Transit has recently identified some issues with malfunctioning hydrogen tank valves that could be contributing to this problem. The agency is working with the tank manufacturer to replace the malfunctioning valves.

- Costs-At this point in the development of FCEB technology, costs continue to be high. Capital costs of the buses have dropped from that of early designs at more than $\$ 3$ million, but they are still much higher than conventional diesel costs. Manufacturers project costs to decrease with larger orders of buses. Operating costs for the FCEBs are also higher due to several factors. As mentioned earlier, maintenance staff is still learning the new technology and spends more time troubleshooting advanced systems. Now that the buses are out of the original warranty period, parts costs have increased dramatically. The costs for advanced-technology parts are also much higher than that of conventional technology. AC Transit has purchased extended warranty agreements with the manufacturers that also add to the cost. This cost curve is typical of any new technology being introduced into the market and is expected to drop over time.

- Extended downtime-AC Transit has experienced issues with specific buses that resulted in long periods of downtime. FC6 was out of service for most of the data period. The issue was originally believed to be a problem with the hybrid system. Troubleshooting proved challenging, but the issue was eventually traced to the bus cooling system. The water pump in the cooling system caused a short in the high voltage 
system. The bus has been repaired and is back in service. During this timeframe, there were limited technical resources for diagnosing the issue which further extended the downtime period. Another bus, FC8, has had propulsion-system issues that resulted in several failed inductors and caused extended downtime. AC Transit replaced the FCPP with a spare and changed out some hybrid system components and is not seeing the issue. The bus is currently operating with the spare FCPP; however this is not the optimal solution unless the original FCPP has reached the end of life. The agency is working with the manufacturers to identify what caused the issue and determine how to prevent the problem in the future.

\section{Progress Toward Meeting Technical Targets for Fuel Cell Systems}

Increasing the durability and reliability of the fuel cell system to meet transit requirements continues to be a key challenge. FTA life cycle requirements for a full size transit bus are 12 years or 500,000 miles. Because transit agencies typically rebuild the diesel engines at approximately mid-life, an FCPP should be able to operate for at least half the life of the bus. DOE/FTA have set an early performance target of 4-6 years (or 20,000-30,000 hours) durability for the fuel cell propulsion system. The ZEBA buses continue to demonstrate some of the highest hours for FCEBs in service. As mentioned in previous reports, three of the FCPPs in the ZEBA buses had accumulated hours in service prior to being installed in the new buses. Those three FCPPs continue to operate and accumulate hours in service.

Figure 16 shows the cumulative hours on each FCPP through December 2014. The top FCPP has now achieved more than 18,000 hours of operation without major repair or cell replacements. This is the highest number of FCPP hours documented for a FCEB; it surpasses the 2016 target and moves the technology further toward meeting the ultimate target of 25,000 hours. In all, 64\% of these FCPPs ( 9 out of 14 ) have surpassed 9,000 hours of operation. Table 3 provides the total hours accumulated on each of the FCPPs since they were installed. The table includes the hours for the spare FCPP as well as the 12 original FCPPs. 
Fuel Cell Power Plant Hours of Operation for ZEBA Buses

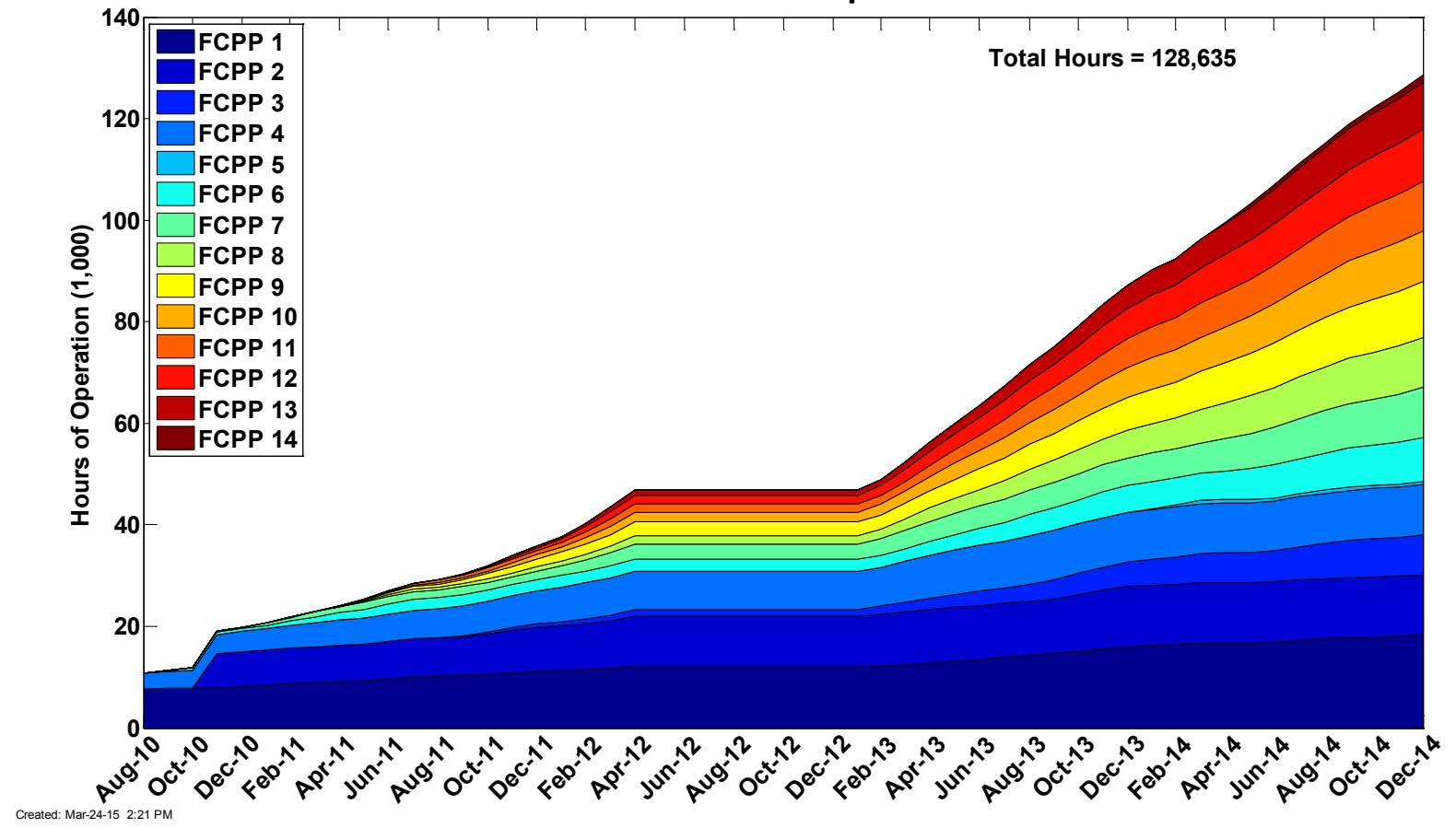

Figure 16. Cumulative FCPP hours on the ZEBA buses

Table 3. Total Hours Accumulated on the FCPPs

\begin{tabular}{|c|c|c|c|}
\hline FCPP & $\begin{array}{c}\text { Date of FCPP } \\
\text { Installation }\end{array}$ & $\begin{array}{c}\text { FCPP Hours } \\
\text { at Installation }\end{array}$ & $\begin{array}{c}\text { Total Hours } \\
\text { through } \\
\text { December 2014 }\end{array}$ \\
\hline 1 & $8 / 22 / 10$ & 59 & 8,641 \\
\hline 2 & $8 / 20 / 10$ & 20 & 9,869 \\
\hline 3 & $8 / 1 / 10$ & 2,915 & 9,954 \\
\hline 4 & $8 / 29 / 10$ & 7,727 & 18,299 \\
\hline 5 & $11 / 15 / 10$ & 6,806 & 11,909 \\
\hline 6 & $2 / 22 / 11$ & 34 & 9,763 \\
\hline 7 & $3 / 1 / 11$ & 20 & 11,071 \\
\hline 8 & $5 / 5 / 11$ & 0 & 9,969 \\
\hline 9 & $5 / 12 / 11$ & 0 & 9,810 \\
\hline 10 & $8 / 17 / 11$ & 0 & 10,327 \\
\hline 11 & $8 / 15 / 11$ & 0 & 7,839 \\
\hline 12 & $9 / 30 / 11$ & 0 & 9,168 \\
\hline 13 (spare) & $4 / 3 / 14$ & 23 & 1,419 \\
\hline
\end{tabular}




\section{Evaluation Results}

The results presented in this section are focused on data from November 2013 through December 2014. During that data period, the FCEBs operated 417,757 miles over 49,421 hours of fuel cell operation. This indicates an overall operational speed of $8.5 \mathrm{mph}$. As mentioned previously, FC6 had an issue that kept it out of service for 14 months. The bus was repaired and went back into service in December 2014. The intermittent nature of the problem made diagnosis a challenge and resulted in the extended downtime. FC6 accumulated fewer than 1,000 miles during the data period, resulting in performance that was not representative of that of the overall fleet. The performance indicators of monthly miles, availability, and costs were significantly affected by the downtime of this bus. The analysis results presented in this section include the overall fleet average as well as the adjusted average with this outlier bus removed.

The diesel baseline buses include four Van Hool buses that are the same model as the FCEBs and ten newer Gillig buses in operation at AC Transit.

\section{Route Assignments}

The FCEBs have been operating from AC Transit's Emeryville Division for the majority of the evaluation period presented here. Four buses were transferred to the Oakland Division toward the end of the evaluation period once its fueling station was operational. Earlier in the demonstration, AC Transit operated the fuel cell and Van Hool diesel study buses on a specific set of route blocks on the 18 and 51B local routes. AC Transit has now increased service of the FCEBs to include most routes out of Emeryville, with the exception of any commuter routes such as Transbay service. The buses at the Oakland Division are also randomly dispatched on any of the local routes serviced by 40 -foot buses. This is the common practice for most transit agencies. Operating the FCEBs on any route from a depot contributes to full commercialization because it means the technology is closer to being able to replace a conventional diesel bus with little to no operational or service modifications.

The Emeryville Division has 12 local routes that are served by 40 -foot buses and the Oakland division has 16 . Table 4 provides a summary of the local routes that the FCEBs could be operated on at each of the depots. The data include deadhead as well as in-service time. The average speed at the two depots is similar at around $10 \mathrm{mph}$.

Table 4. Summary of Local Routes for ZEBA Buses

\begin{tabular}{|l|r|r|r|r|r|}
\hline Depot & Routes & Blocks & \multicolumn{1}{c|}{$\begin{array}{c}\text { Time } \\
(\mathbf{h})\end{array}$} & $\begin{array}{c}\text { Distance } \\
(\mathrm{mi})\end{array}$ & $\begin{array}{c}\text { Average } \\
\text { Speed } \\
(\mathrm{mph})\end{array}$ \\
\hline Emeryville & 12 & 73 & $1,095.3$ & 10,888 & 9.94 \\
\hline Oakland & 16 & 83 & 957.8 & 9,946 & 10.38 \\
\hline
\end{tabular}

\section{Bus Use and Availability}

Bus use and availability are indicators of reliability. Lower bus usage may indicate downtime for maintenance or purposeful reduction of planned work for the buses. This section summarizes bus usage and availability for the FCEBs and baseline buses. 
Table 5 summarizes average monthly mileage for the study buses for the data period. Currently, the average monthly operating mileage for the FCEBs is 2,487 miles, which is $43 \%$ less than that of the Van Hool diesel buses and $49 \%$ less than that of the Gillig diesel buses. If you remove the outlier bus from the calculation, the average monthly mileage rises to 2,707. Figure 17 shows the average monthly mileage for the FCEBs and diesel buses since November 2013 and includes the adjusted data without FC6. The monthly mileage for the FCEBs was consistently over 2,000 per month during the data period with the exception of February 2014. The Emeryville station was out of service for almost two weeks during that month, which resulted in the buses being temporarily pulled from service. The buses need to increase operation to meet a general transit target of 3,000 miles per month.

Table 5. Average Monthly Mileage (Evaluation Period)

\begin{tabular}{|c|c|c|c|c|c|}
\hline Bus & $\begin{array}{c}\text { Starting } \\
\text { Hubodometer }\end{array}$ & $\begin{array}{c}\text { Ending } \\
\text { Hubodometer }\end{array}$ & $\begin{array}{c}\text { Total } \\
\text { Mileage }\end{array}$ & Months & $\begin{array}{c}\text { Average } \\
\text { Monthly } \\
\text { Mileage }\end{array}$ \\
\hline FC4 & 50,676 & 78,710 & 29,103 & 14 & 2,079 \\
\hline FC5 & 52,899 & 89,892 & 40,028 & 14 & 2,859 \\
\hline FC6 & 63,740 & 64,664 & 924 & 14 & 66 \\
\hline FC7 & 66,128 & 98,960 & 32,832 & 14 & 2,345 \\
\hline FC8 & 37,669 & 54,379 & 16,710 & 14 & 1,194 \\
\hline FC9 & 40,544 & 82,595 & 42,051 & 14 & 3,004 \\
\hline FC10 & 48,343 & 88,802 & 40,459 & 14 & 2,890 \\
\hline FC11 & 43,189 & 84,309 & 41,120 & 14 & 2,937 \\
\hline FC12 & 39,841 & 87,352 & 47,511 & 14 & 3,394 \\
\hline FC14 & 45,331 & 92,724 & 47,393 & 14 & 3,385 \\
\hline FC15 & 37,538 & 69,678 & 32,140 & 14 & 2,296 \\
\hline FC16 & 35,881 & 83,367 & 47,486 & 14 & 3,392 \\
\hline Total ZEBA & & & $\mathbf{4 1 7 , 7 5 7}$ & $\mathbf{1 6 8}$ & $\mathbf{2 , 4 8 7}$ \\
\hline ZEBA adjusted (w/o FC6) & & $\mathbf{4 1 6 , 8 3 3}$ & $\mathbf{1 5 4}$ & $\mathbf{2 , 7 0 7}$ \\
\hline 1208 & 217,599 & 274,721 & 40,048 & 10 & 4,005 \\
\hline 1209 & 220,257 & 281,945 & 61,520 & 14 & 4,394 \\
\hline 1210 & 201,820 & 263,249 & 61,429 & 14 & 4,388 \\
\hline 1211 & 79,648 & 143,084 & 63,172 & 14 & 4,512 \\
\hline Total VH Diesel & & & $\mathbf{2 2 6 , 1 6 9}$ & $\mathbf{5 2}$ & $\mathbf{4 , 3 4 9}$ \\
\hline 1338 & 25,555 & 91,456 & 66,143 & 14 & 4,725 \\
\hline 1339 & 26,604 & 95,103 & 69,676 & 14 & 4,977 \\
\hline 1340 & 26,178 & 98,348 & 72,170 & 14 & 5,155 \\
\hline 1341 & 27,435 & 98,610 & 71,175 & 14 & 5,084 \\
\hline 1342 & 27,597 & 98,659 & 71,062 & 14 & 5,076 \\
\hline 1343 & 26,920 & 87,523 & 60,609 & 14 & 4,329 \\
\hline 1344 & 27,105 & 98,357 & 72,243 & 14 & 5,160 \\
\hline 1345 & 23,736 & 90,464 & 67,820 & 14 & 4,844 \\
\hline 1346 & 20,200 & 87,237 & 67,215 & 14 & 4,801 \\
\hline 1347 & 13,575 & 81,143 & 67,568 & 14 & 4,826 \\
\hline Total Gillig Diesel & & & $\mathbf{6 8 5 , 6 8 1}$ & $\mathbf{1 4 0}$ & $\mathbf{4 , 8 9 8}$ \\
\hline
\end{tabular}




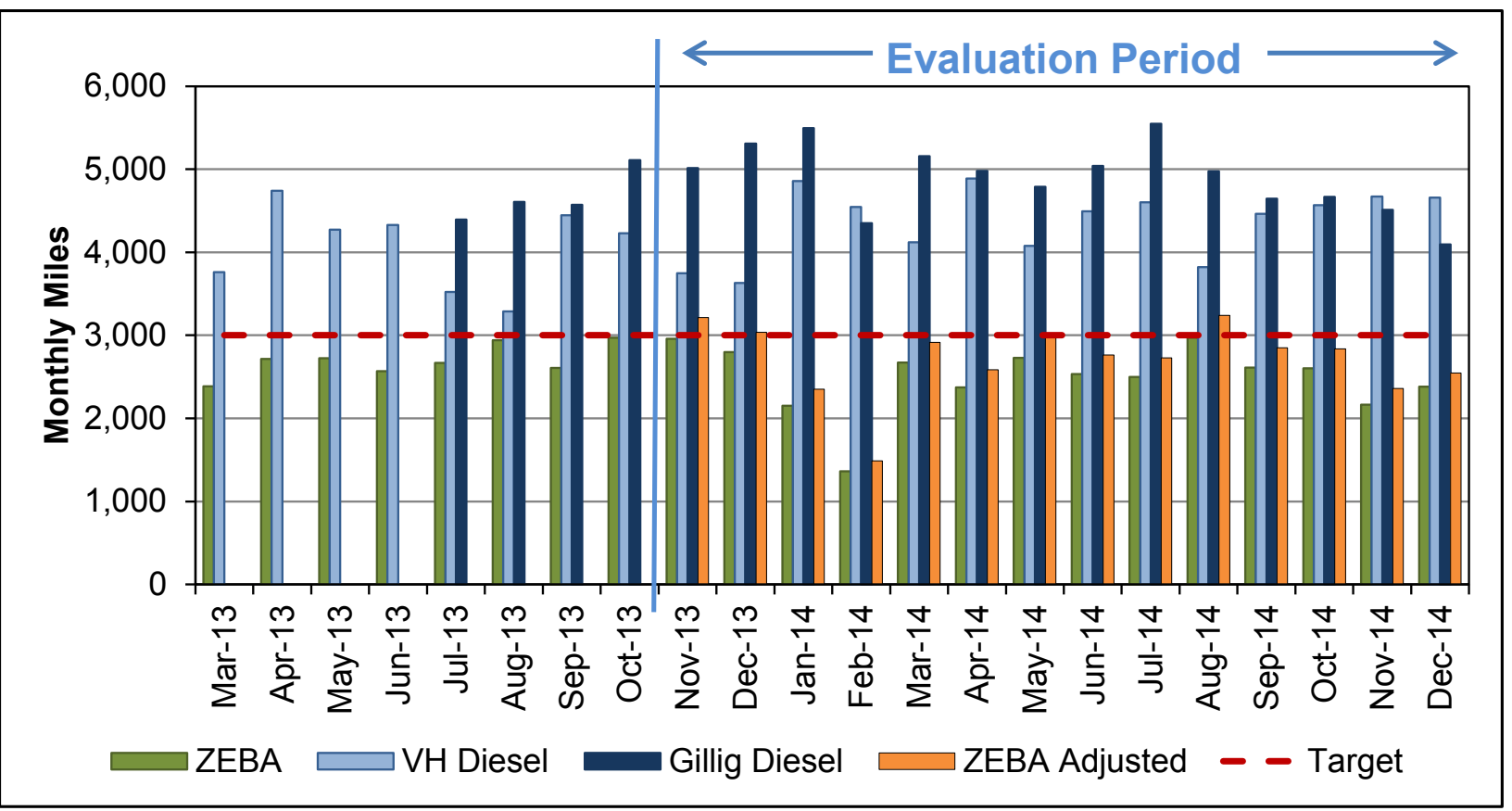

Figure 17. Monthly average miles for the ZEBA FCEBs and diesel buses

Another measure of reliability is availability - the percentage of days the buses are actually available out of days that the buses are planned for operation. Figure 18 shows availability for the FCEBs (green line) and diesel buses (medium blue line for the Van Hool buses, dark blue line for the Gillig buses) from March 2013 through December 2014. The adjusted average availability for the ZEBA buses without FC6 is also shown in the graph (orange line) to indicate how the extended downtime affected the data. The ZEBA availability for the data period was $72 \%$ but it is showing a general upward trend. The figure also provides an indication of the reasons for unavailability. The stacked bars for each month show the number of days the FCEBs were not available by six categories. The unavailability of the Emeryville hydrogen station in late January and early February 2014 lowered the availability of the buses during those two months. 


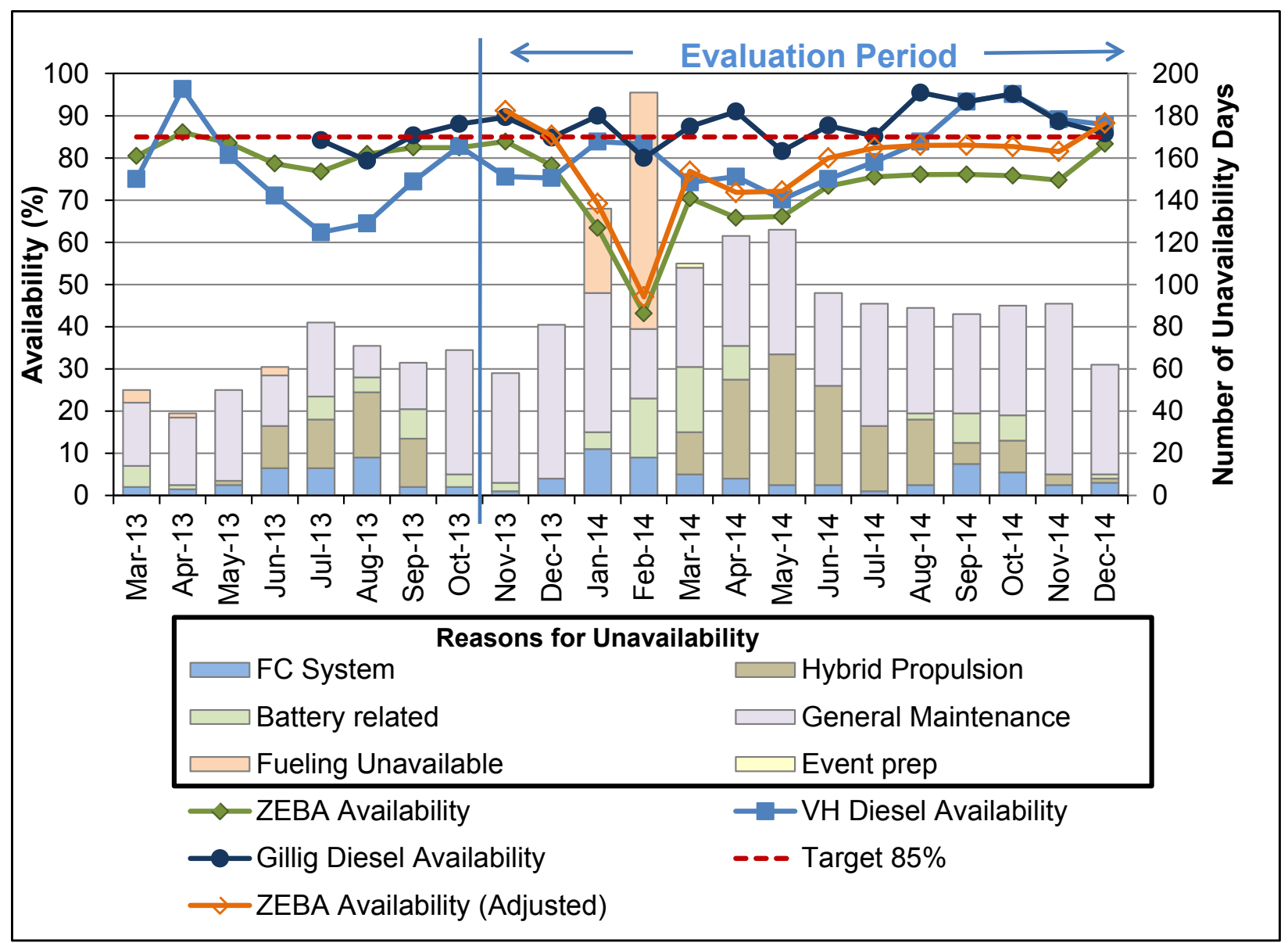

Figure 18. Availability for the ZEBA FCEBs and diesel buses

Table 6 shows the availability numbers for each of the 12 ZEBA buses. The availability for the individual ZEBA buses ranged from a low of $2 \%$ to a high of $92 \%$. The overall average availability for the fleet is $72 \%$. If FC6 is removed from the calculation, the average availability for the FCEBs is $78 \%$. A second bus-FC8 - developed an issue with the propulsion system that kept it out of service for about 5 months during this time. The issues for these two buses were described in the previous section. 
Table 6. Summary of ZEBA Availability by Bus (Evaluation Period)

\begin{tabular}{|c|c|c|c|}
\hline Bus & $\begin{array}{c}\text { Planned } \\
\text { Days }\end{array}$ & $\begin{array}{c}\text { Available } \\
\text { Days }\end{array}$ & $\begin{array}{c}\text { Percent } \\
\text { Availability }\end{array}$ \\
\hline FC4 & 426 & 316 & $74 \%$ \\
\hline FC5 & 426 & 339 & $80 \%$ \\
\hline FC6 & 426 & 10 & $2 \%$ \\
\hline FC7 & 426 & 317 & $74 \%$ \\
\hline FC8 & 426 & 158 & $37 \%$ \\
\hline FC9 & 426 & 367 & $86 \%$ \\
\hline FC10 & 426 & 394 & $92 \%$ \\
\hline FC11 & 426 & 379 & $89 \%$ \\
\hline FC12 & 426 & 355 & $83 \%$ \\
\hline FC14 & 426 & 387 & $91 \%$ \\
\hline FC15 & 426 & 278 & $65 \%$ \\
\hline FC16 & 426 & 382 & $90 \%$ \\
\hline Total ZEBA & $\mathbf{5 , 1 1 2}$ & $\mathbf{3 , 6 8 2}$ & $\mathbf{7 2 \%}$ \\
\hline ZEBA adjusted (w/o FC6) & $\mathbf{4 , 6 8 6}$ & $\mathbf{3 , 6 7 2}$ & $\mathbf{7 8 \%}$ \\
\hline
\end{tabular}

Table 7 summarizes the reasons for unavailability for the fuel cell and diesel buses. During this reporting period, the average availability was $72 \%$ for the FCEBs, $82 \%$ for the Van Hool diesel buses, and $88 \%$ for the Gillig buses. Bus-related maintenance (separate from the fuel cell, hybrid, and traction battery systems) is the reason for the highest percentage of unavailability for the ZEBA buses. The availability data for the diesel buses has not been detailed enough to separate out specific reasons for unavailability until around August 2014. NREL should have sufficient data to separate the reasons for the diesel bus unavailability in future reports.

Table 7. Summary of Availability and Unavailability of Buses for Service (Evaluation Period)

\begin{tabular}{|l|c|c|c|c|c|c|}
\hline \multicolumn{1}{|c|}{ Category } & $\begin{array}{c}\text { ZEBA } \\
\text { \# Days }\end{array}$ & $\begin{array}{c}\text { ZEBA } \\
\%\end{array}$ & $\begin{array}{c}\text { VH } \\
\text { Diesel } \\
\text { \# Days }\end{array}$ & $\begin{array}{c}\text { VH } \\
\text { Diesel } \\
\%\end{array}$ & $\begin{array}{c}\text { Gillig } \\
\text { Diesel } \\
\text { \# Days }\end{array}$ & $\begin{array}{c}\text { Gillig } \\
\text { Diesel } \\
\%\end{array}$ \\
\hline Planned work days & 5,112 & & 1,492 & & 4,260 & \\
\hline Days available & 3,682 & $\mathbf{7 2}$ & 1,222 & $\mathbf{8 2}$ & 3,762 & $\mathbf{8 8}$ \\
\hline Unavailable & $\mathbf{1 , 4 3 0}$ & $\mathbf{1 0 0}$ & $\mathbf{2 7 0}$ & $\mathbf{1 0 0}$ & $\mathbf{4 9 8}$ & $\mathbf{1 0 0}$ \\
\hline Fuel cell propulsion & 122 & 6.4 & & & & \\
\hline Hybrid propulsion & 270 & 14.1 & & & & \\
\hline Traction battery issues & 118 & 6.2 & & & & \\
\hline Bus maintenance & 766 & 40.0 & 270 & 100 & 498 & 100 \\
\hline Fuel unavailable & 152 & 7.9 & & & & \\
\hline Event prep & 2 & 0.1 & & & & \\
\hline
\end{tabular}

\section{Fuel Economy and Cost}

As discussed above, hydrogen fuel is provided by two fueling stations designed and constructed by Linde. The Emeryville station was responsible for fueling the buses throughout the data period. The Oakland station began fueling buses in November 2014. For both stations, hydrogen is dispensed at up to 350 bar (5,000 psi). AC Transit employees perform all fueling services for the hydrogen-fueled vehicles. NREL collects fueling records from three sources: electronic 
records from AC Transit's Fleet Watch system, electronic fueling records from Linde, and manual logs from AC Transit. These records are merged for the analysis.

Table 8 shows hydrogen and diesel fuel consumption and fuel economy for the study buses during the reporting period. The FCEBs had an overall average fuel economy of 6.40 miles per kilogram of hydrogen, which equates to 7.23 miles per diesel gallon equivalent (DGE). The energy conversion from kilograms of hydrogen to DGE appears at the end of Appendix B. (Appendices B through $\mathrm{G}$ contain summary statistics for the ZEBA and diesel buses.) These results indicate that the FCEBs have an average fuel economy that is $83 \%$ higher than that of the Van Hool diesel buses and $66 \%$ higher than that of the Gillig diesel buses.

Figure 19 shows monthly average fuel economy for the FCEBs and diesel buses in miles per DGE. The average monthly high temperature is included in the graph to track any seasonal variations in the fuel economy due to heating or cooling of the bus, which might require additional energy use.

Table 8. Fuel Use and Economy (Evaluation Period)

\begin{tabular}{|c|c|c|c|c|c|}
\hline Bus & $\begin{array}{l}\text { Mileage } \\
\text { (fuel base) }\end{array}$ & $\begin{array}{l}\text { Hydrogen } \\
\text { (kg) }\end{array}$ & $\begin{array}{l}\text { Miles per } \\
\text { kg }\end{array}$ & $\begin{array}{l}\text { Diesel } \\
\text { (DGE) }\end{array}$ & $\begin{array}{l}\text { Miles per } \\
\text { DGE }\end{array}$ \\
\hline FC4 & 26,909 & 4,531 & 5.94 & 4,010 & 6.71 \\
\hline FC5 & 35,193 & 5,277 & 6.67 & 4,670 & 7.54 \\
\hline FC6 & 924 & 153 & 6.04 & 135 & 6.82 \\
\hline FC7 & 27,436 & 4,488 & 6.11 & 3,971 & 6.91 \\
\hline FC8 & 14,883 & 2,436 & 6.11 & 2,156 & 6.90 \\
\hline FC9 & 39,183 & 5,883 & 6.66 & 5,206 & 7.53 \\
\hline FC10 & 38,187 & 6,154 & 6.21 & 5,446 & 7.01 \\
\hline FC11 & 38,271 & 6,092 & 6.28 & 5,391 & 7.10 \\
\hline FC12 & 44,301 & 6,485 & 6.83 & 5,739 & 7.72 \\
\hline FC14 & 45,648 & 6,709 & 6.80 & 5,937 & 7.69 \\
\hline FC15 & 29,458 & 4,838 & 6.09 & 4,281 & 6.88 \\
\hline FC16 & 43,667 & 6,940 & 6.29 & 6,142 & 7.11 \\
\hline ZEBA Total & 384,060 & 59,986 & 6.40 & 53,085 & 7.23 \\
\hline 1208 & 36,351 & & & 9,094 & 4.00 \\
\hline 1209 & 58,901 & & & 15,589 & 3.78 \\
\hline 1210 & 58,093 & & & 14,230 & 4.08 \\
\hline 1211 & 60,030 & & & 15,123 & 3.97 \\
\hline VH Diesel Total & 213,374 & & & 54,037 & 3.95 \\
\hline 1338 & 60,547 & & & 14,440 & 4.19 \\
\hline 1339 & 65,401 & & & 15,095 & 4.33 \\
\hline 1340 & 69,684 & & & 16,052 & 4.34 \\
\hline 1341 & 69,085 & & & 15,674 & 4.41 \\
\hline 1342 & 69,574 & & & 15,771 & 4.41 \\
\hline 1343 & 57,327 & & & 13,294 & 4.31 \\
\hline 1344 & 67,716 & & & 15,448 & 4.38 \\
\hline 1345 & 62,944 & & & 14,308 & 4.40 \\
\hline 1346 & 63,992 & & & 14,504 & 4.41 \\
\hline 1347 & 64,961 & & & 14,825 & 4.38 \\
\hline Gillig Diesel Total & 651,233 & & & 149,411 & 4.36 \\
\hline
\end{tabular}




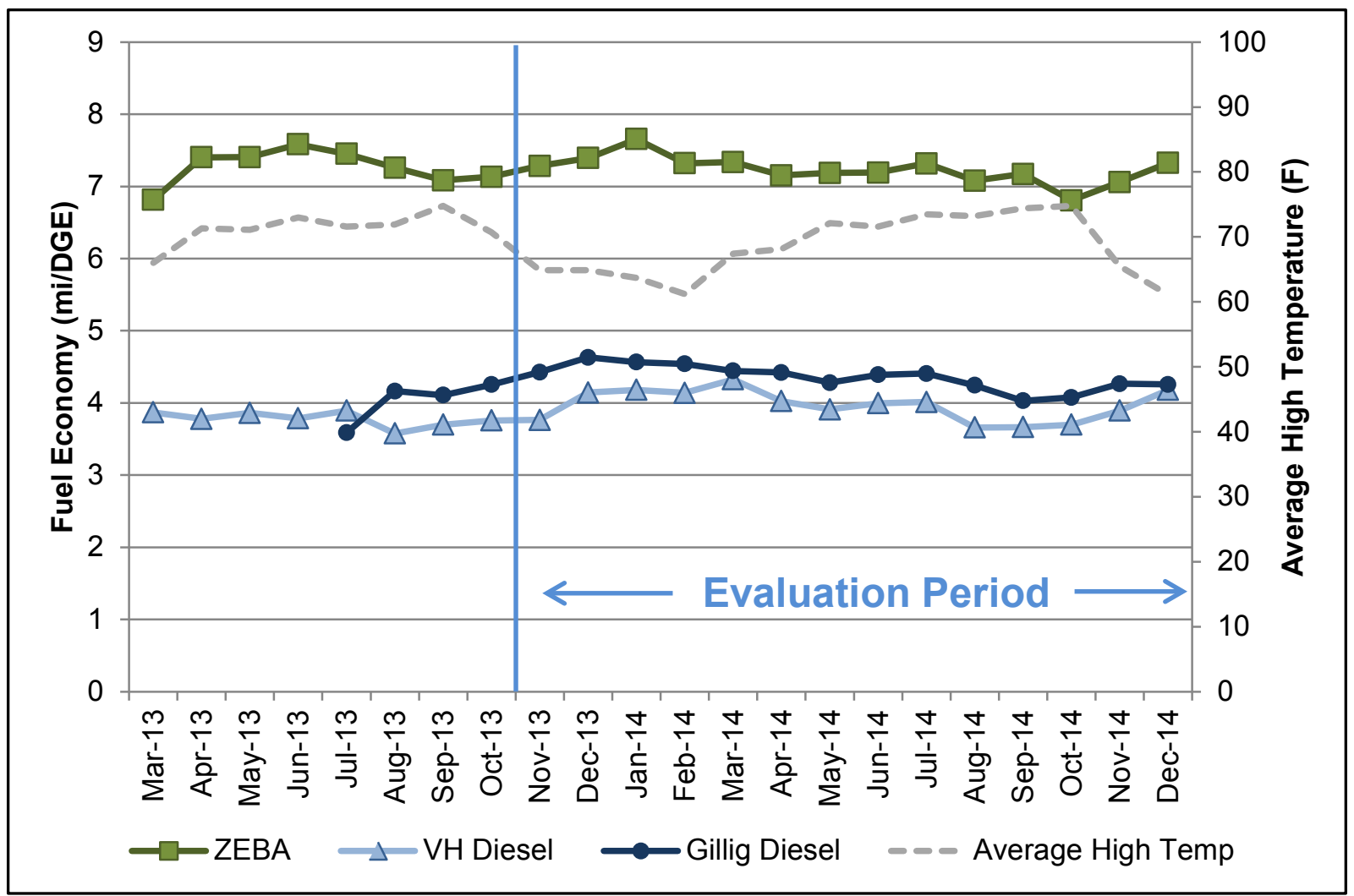

Figure 19. Average fuel economy for the fuel cell and diesel buses (evaluation period)

Table 9 provides the summary of fuel costs for the ZEBA and diesel baseline buses for the evaluation period. The cost of hydrogen production as dispensed during this period was $\$ 9.10$ per kilogram, not including the capital cost of the station. The hydrogen fuel cost per mile calculates to $\$ 1.42$. Diesel fuel cost during the reporting period was $\$ 2.87$ per gallon, which calculates to $\$ 0.73$ per mile for the Van Hool diesel buses and $\$ 0.66$ per mile for the Gillig diesel buses.

Table 9. Summary of Fuel Cost for ZEBA and Diesel Buses (Evaluation Period)

\begin{tabular}{|l|c|c|c|}
\hline & ZEBA & Van Hool & Gillig \\
\hline Cost per unit (kg or gal) & $\$ 9.10$ & $\$ 2.87$ & $\$ 2.87$ \\
\hline Total miles (fuel base) & 384,060 & 213,374 & 651,233 \\
\hline Total fuel (kg or gal) & 59,986 & 54,037 & 149,411 \\
\hline Fuel cost $(\$)$ & $\$ 546,040$ & $\$ 154,918$ & $\$ 428,346$ \\
\hline Fuel cost per mile $(\$)$ & $\$ 1.42$ & $\$ 0.73$ & $\$ 0.66$ \\
\hline
\end{tabular}




\section{Roadcall Analysis}

A roadcall or revenue vehicle system failure (as named in the National Transit Database ${ }^{14}$ ) is defined as a failure of an in-service bus that causes the bus to be replaced on route or causes a significant delay in schedule. ${ }^{15}$ If the problem with the bus can be repaired during a layover and the schedule is kept, this is not considered a roadcall. The analysis described here includes only roadcalls that were caused by "chargeable" failures. Chargeable roadcalls include systems that can physically disable the bus from operating on route, such as interlocks (doors, air system), engine, or things that are deemed to be safety issues if operation of the bus continues. They do not include roadcalls for things such as problems with radios, fareboxes, or destination signs.

The transit industry measures reliability as mean distance between failures, also documented as miles between roadcall (MBRC). Table 10 provides the MBRC for the FCEBs and diesel buses categorized by bus roadcalls and propulsion-related-only roadcalls. Propulsion-related-only roadcalls include all roadcalls due to propulsion-related systems including the fuel cell system (or engine for a conventional bus), electric drive, fuel, exhaust, air intake, cooling, non-lighting electrical, and transmission systems. The fuel-cell-related roadcalls and MBRC are included for the FCEBs. The fuel cell system MBRC includes any roadcalls due to issues with the fuel cell stack or associated balance of plant. Figure 20 presents the cumulative MBRC by category for the FCEBs and diesel baseline buses. The bus MBRC for the ZEBA buses is showing a slow increase over time and has surpassed the target of 4,000 miles. The fuel cell MBRC shows a steady increase and has passed the DOE/FTA 2016 target of 15,000 miles and is nearing the ultimate target of 20,000 miles.

Table 10. Roadcalls and MBRC (Cumulative and Evaluation Period)

\begin{tabular}{|l|c|c|c|c|c|c|}
\hline & $\begin{array}{c}\text { ZEBA } \\
\text { Cumulative } \\
\text { Total }\end{array}$ & $\begin{array}{c}\text { ZEBA } \\
\text { Evaluation } \\
\text { Period }\end{array}$ & $\begin{array}{c}\text { Van Hool } \\
\text { Diesel } \\
\text { Cumulative } \\
\text { Total }\end{array}$ & $\begin{array}{c}\text { Van Hool } \\
\text { Diesel } \\
\text { Evaluation } \\
\text { Period }\end{array}$ & $\begin{array}{c}\text { Gillig } \\
\text { Diesel } \\
\text { Cumulative } \\
\text { Total }\end{array}$ & $\begin{array}{c}\text { Gillig } \\
\text { Diesel } \\
\text { Evaluation } \\
\text { Period }\end{array}$ \\
\hline Dates & $9 / 11-12 / 14$ & $\begin{array}{c}11 / 13- \\
12 / 14\end{array}$ & $9 / 11-12 / 14$ & $\begin{array}{c}11 / 13- \\
12 / 14\end{array}$ & $6 / 13-12 / 14$ & $\begin{array}{c}11 / 13- \\
12 / 14\end{array}$ \\
\hline Mileage & 843,242 & 417,757 & 430,147 & 226,169 & 872,487 & 685,681 \\
\hline Bus roadcalls & 193 & 67 & 124 & 53 & 125 & 82 \\
\hline Bus MBRC & 4,369 & 6,235 & 3,469 & 4,267 & 6,980 & 8,362 \\
\hline $\begin{array}{l}\text { Propulsion } \\
\text { roadcalls }\end{array}$ & 120 & 40 & 55 & 23 & 42 & 27 \\
\hline $\begin{array}{l}\text { Propulsion } \\
\text { MBRC }\end{array}$ & 7,027 & 10,444 & 7,821 & 9,833 & 20,774 & 25,396 \\
\hline $\begin{array}{l}\text { Fuel cell } \\
\text { roadcalls }\end{array}$ & 43 & 12 & N/A & N/A & N/A & N/A \\
\hline Fuel cell MBRC & 19,610 & 34,813 & N/A & N/A & N/A & N/A \\
\hline
\end{tabular}

\footnotetext{
${ }^{14}$ National Transit Database website: www.ntdprogram.gov/ntdprogram/.

${ }^{15}$ AC Transit defines a significant delay as 6 or more minutes.
} 


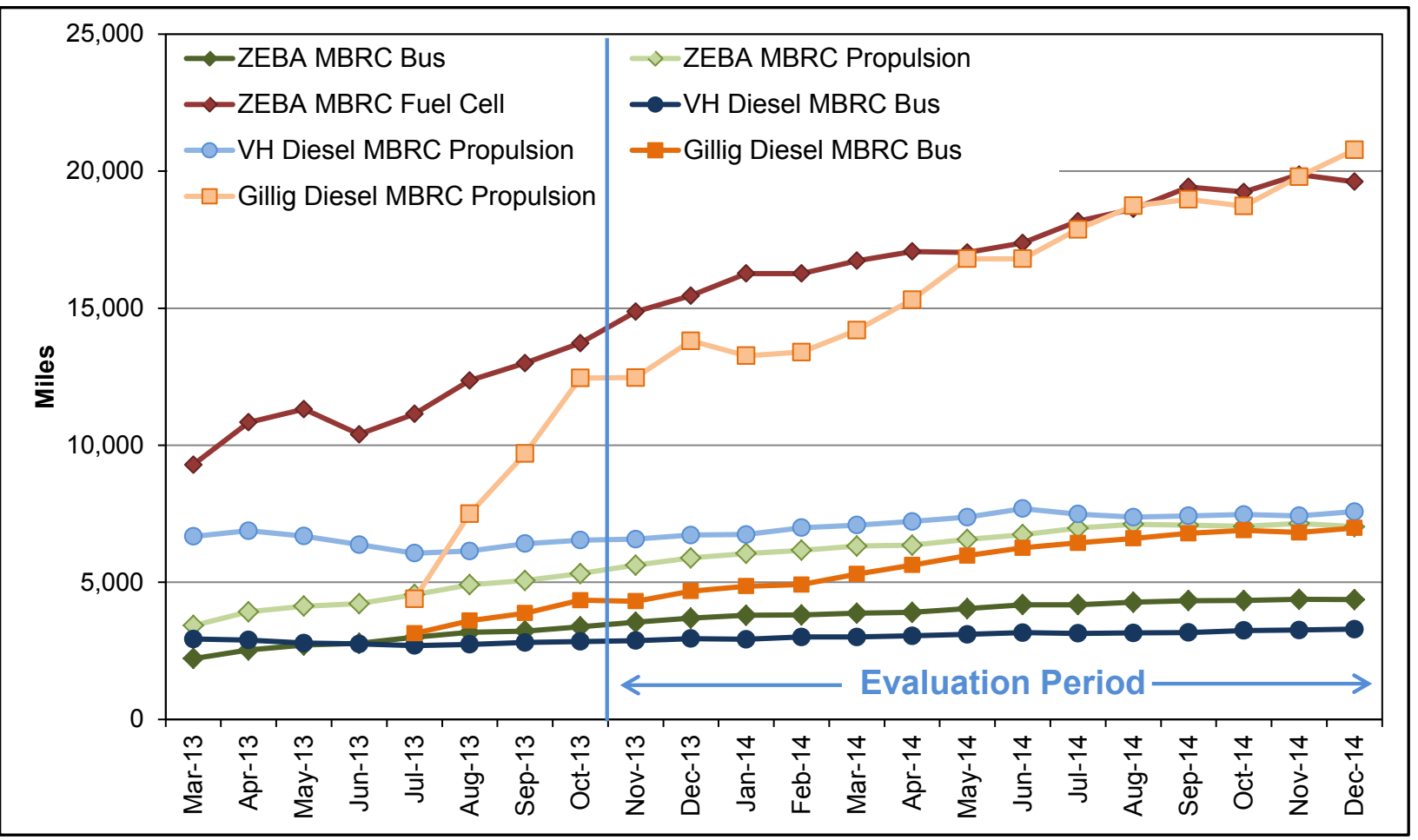

Figure 20. Cumulative MBRC for the FCEBs and diesel buses

\section{Maintenance Analysis}

All work orders for the study buses were collected and analyzed for this evaluation. For consistency, the maintenance labor rate was kept at a constant $\$ 50$ per hour; this does not reflect an average rate for AC Transit. Costs for accident-related repair, which are extremely variable from bus to bus, were eliminated from the analysis. This section first covers total maintenance costs and then maintenance costs by bus system. Warranty costs are not included in the cost-permile calculations. As mentioned previously, the Van Hool buses are no longer under warranty, which has resulted in increased maintenance costs since the last report. The ZEBA buses are now beyond the term for the original warranty. As mentioned previously, AC Transit has entered into extended warranty agreements with US Hybrid and EnerDel. The cost of these agreements was funded through a grant from FTA as part of the National Fuel Cell Bus Program. The cost for the agreements is outlined in the summary costs at the end of this section.

\section{Total Work Order Maintenance Costs}

Total maintenance costs include the price of parts and labor rates at $\$ 50$ per hour. Cost per mile is calculated as follows:

$$
\text { Cost per mile }=[(\text { labor hours } * 50)+\text { parts cost }] / \text { mileage }
$$

Table 11 shows total maintenance costs for the fuel cell and diesel buses. Scheduled and unscheduled maintenance cost per mile is provided for each bus and study group of buses. Since the last report, AC Transit has continued to transition all maintenance to its staff. During the earlier part of the demonstration, the FCEB maintenance was supported by an on-site engineer from US Hybrid. The labor hours for this engineer were not included in the data set. AC Transit 
has two mechanics/trainers assigned to maintain the FCEBs and provide maintenance training for other AC Transit staff. By the end of 2014, all regular maintenance tasks had been transitioned to AC Transit staff. The manufacturers provide support as needed with any issues that are encountered with the buses. By February 2015, US Hybrid had trained 22 AC Transit maintenance technicians on diagnostics, service and maintenance of the FCEBs.

During the reporting period, the FCEBs had a 13\% lower cost per mile for maintenance when compared to the Van Hool diesel buses. The Van Hool buses have accumulated more than 4 times the miles of the FCEBs and are at the mid-life point where buses typically have increased costs. The FCEB maintenance costs were more than 2 times higher than the maintenance costs of the Gillig diesel buses.

Table 11. Total Work Order Maintenance Costs (Evaluation Period)

\begin{tabular}{|c|c|c|c|c|c|c|}
\hline Bus & Mileage & Parts $(\$)$ & $\begin{array}{c}\text { Labor } \\
\text { Hours }\end{array}$ & $\begin{array}{c}\text { Total Cost } \\
\text { per Mile } \\
(\$)\end{array}$ & $\begin{array}{c}\text { Scheduled } \\
\text { Cost per } \\
\text { Mile }(\$)\end{array}$ & $\begin{array}{c}\text { Unscheduled } \\
\text { Cost per Mile } \\
(\$)\end{array}$ \\
\hline FC4 & 29,103 & 3,540 & 216.2 & 0.49 & 0.22 & 0.28 \\
\hline FC5 & 40,028 & 2,431 & 253.1 & 0.38 & 0.17 & 0.20 \\
\hline FC6 & 924 & 26,999 & 280.8 & 44.42 & 0.11 & 44.31 \\
\hline FC7 & 32,832 & 5,163 & 296.9 & 0.61 & 0.19 & 0.42 \\
\hline FC8 & 16,710 & 3,086 & 269.0 & 0.99 & 0.22 & 0.77 \\
\hline FC9 & 42,051 & 10,792 & 290.7 & 0.60 & 0.22 & 0.38 \\
\hline FC11 & 40,459 & 15,146 & 195.4 & 0.62 & 0.13 & 0.49 \\
\hline FC12 & 41,120 & 8,447 & 239.0 & 0.50 & 0.16 & 0.34 \\
\hline FC14 & 47,511 & 2,233 & 206.9 & 0.26 & 0.13 & 0.13 \\
\hline FC15 & 47,393 & 12,067 & 277.1 & 0.55 & 0.22 & 0.33 \\
\hline FC16 & 32,140 & 2,920 & 219.6 & 0.43 & 0.17 & 0.26 \\
\hline Total ZEBA & 47,486 & 2,440 & 269.1 & 0.33 & 0.16 & 0.18 \\
\hline ZEBA adjusted & $\mathbf{4 1 6 , 7 5 7}$ & $\mathbf{9 5 , 2 6 4}$ & $\mathbf{3 , 0 1 3 . 6}$ & $\mathbf{0 . 5 9}$ & $\mathbf{0 . 1 8}$ & $\mathbf{0 . 4 1}$ \\
\hline 1208 & 40,045 & $\mathbf{6 8 , 2 6 5}$ & $\mathbf{2 , 7 3 2 . 8}$ & $\mathbf{0 . 4 9}$ & $\mathbf{0 . 1 8}$ & $\mathbf{0 . 3 1}$ \\
\hline 1209 & 61,520 & 13,306 & 417.6 & 0.80 & 0.16 & 0.64 \\
\hline 1210 & 61,429 & 19,457 & 511.5 & 0.63 & 0.13 & 0.50 \\
\hline 1211 & 63,172 & 13,596 & 452.4 & 0.57 & 0.15 & 0.60 \\
\hline Total VH Diesel & $\mathbf{2 2 6 , 1 6 6}$ & $\mathbf{5 7 , 5 5 6}$ & $\mathbf{1 , 9 2 1 . 7}$ & $\mathbf{0 . 6 8}$ & $\mathbf{0 . 1 5}$ & $\mathbf{0 . 5 3}$ \\
\hline 1338 & 66143 & 2,020 & 238 & 0.21 & 0.12 & 0.09 \\
\hline 1339 & 69676 & 3,803 & 259 & 0.24 & 0.11 & 0.13 \\
\hline 1340 & 72170 & 5,220 & 235 & 0.23 & 0.12 & 0.12 \\
\hline 1341 & 71175 & 1,917 & 272 & 0.22 & 0.13 & 0.09 \\
\hline 1342 & 71062 & 2,978 & 267 & 0.23 & 0.11 & 0.12 \\
\hline 1343 & 60609 & 2,846 & 315 & 0.31 & 0.13 & 0.18 \\
\hline 1344 & 72243 & 4,556 & 266 & 0.25 & 0.12 & 0.13 \\
\hline 1345 & 67820 & 5,074 & 271 & 0.27 & 0.12 & 0.15 \\
\hline 1346 & 67215 & 3,832 & 275 & 0.26 & 0.13 & 0.14 \\
\hline 1347 & 67568 & 3,590 & 272 & 0.25 & 0.12 & 0.14 \\
\hline Total Gillig Diesel & $\mathbf{6 8 5 , 6 8 1}$ & $\mathbf{3 5 , 8 3 6}$ & $\mathbf{2 , 6 7 0}$ & $\mathbf{0 . 2 5}$ & $\mathbf{0 . 1 2}$ & $\mathbf{0 . 1 3}$ \\
\hline & & & & & & \\
\hline
\end{tabular}


The monthly scheduled and unscheduled cost per mile for the ZEBA buses is shown in Figure 21. Figure 22 provides the same information for the Van Hool buses and Figure 23 shows the Gillig buses' monthly costs. Issues with the ZEBA buses resulted in higher costs for several months during the evaluation period. Problems included issues with bus air compressors, cooling systems, and a DC-DC converter. The high cost of parts was the primary factor for the increases. The figure includes the adjusted cost per mile by month without FC6. The Van Hool diesel buses experienced a number of issues that are typical for buses at this level of mileage. Costs were accrued for work on brakes, axles, fire suppression systems, cooling systems, HVAC, and turbochargers. The Gillig buses show a consistent increase in costs over time. This is expected as the buses accumulate mileage. The higher cost for December 2014 was attributed to maintenance on brakes, charging system, fire suppression system, and a window replacement.

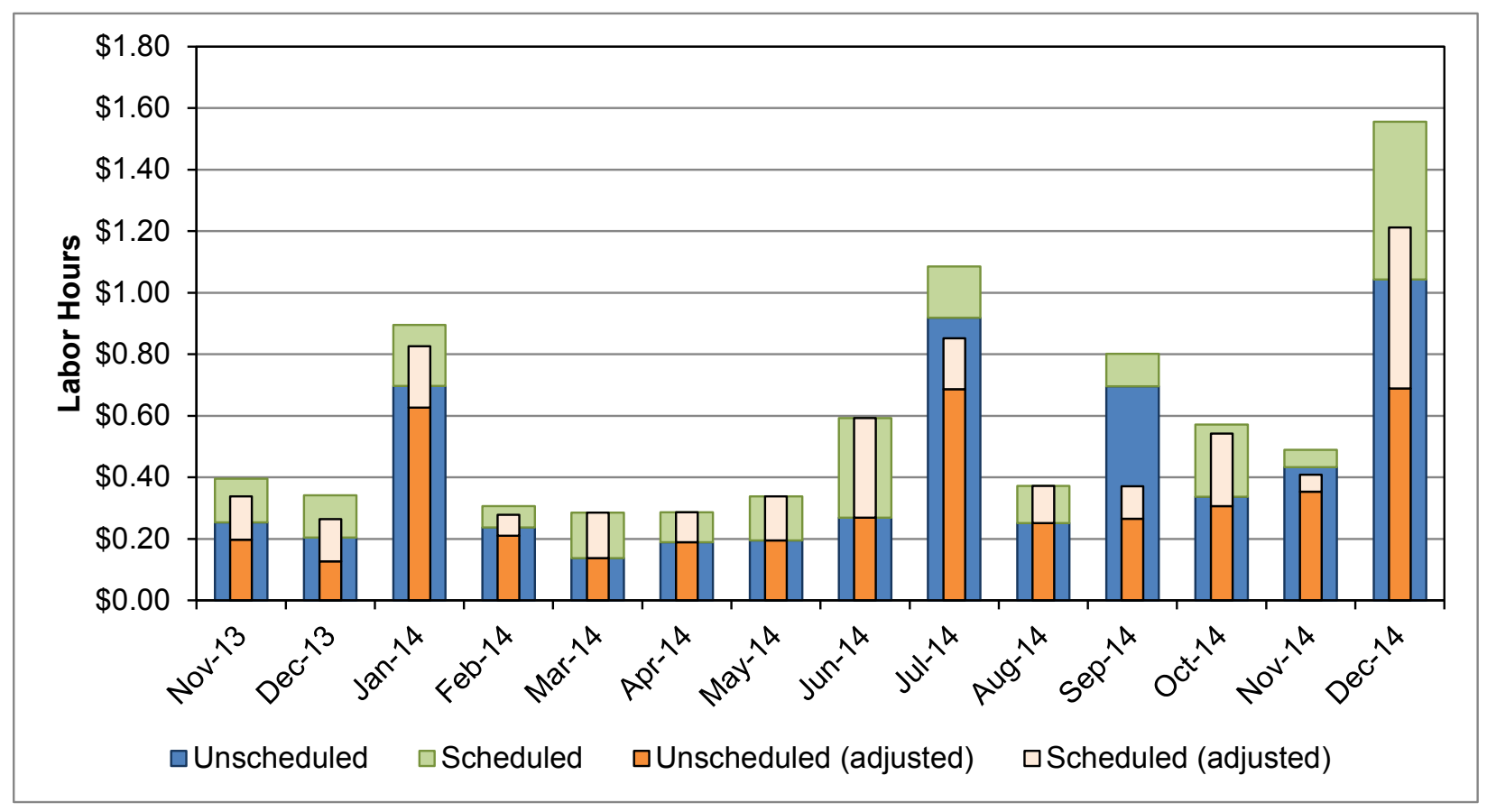

Figure 21. Monthly scheduled and unscheduled costs per mile for the ZEBA buses (evaluation period) 


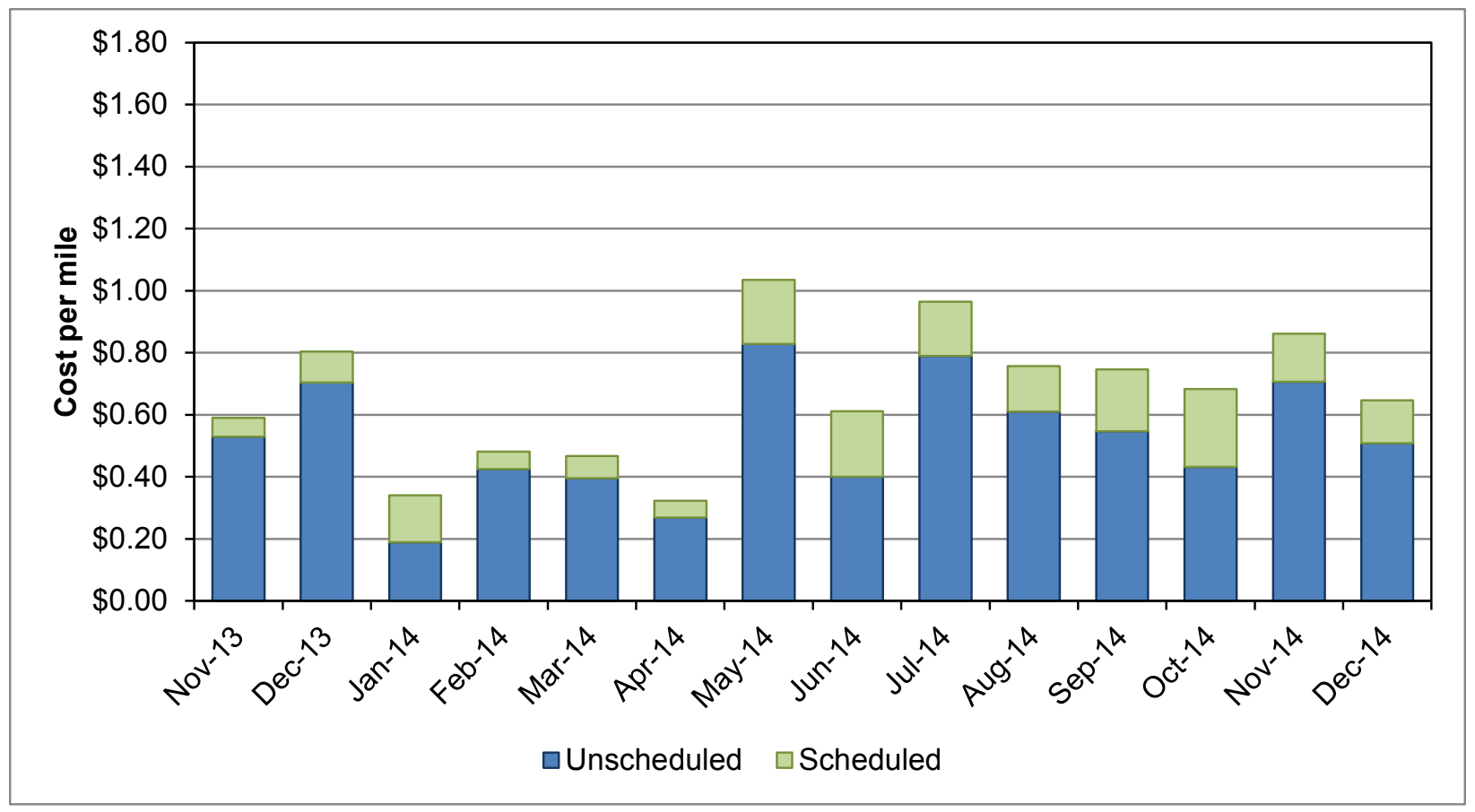

Figure 22. Monthly scheduled and unscheduled costs per mile for the Van Hool diesel buses (evaluation period)

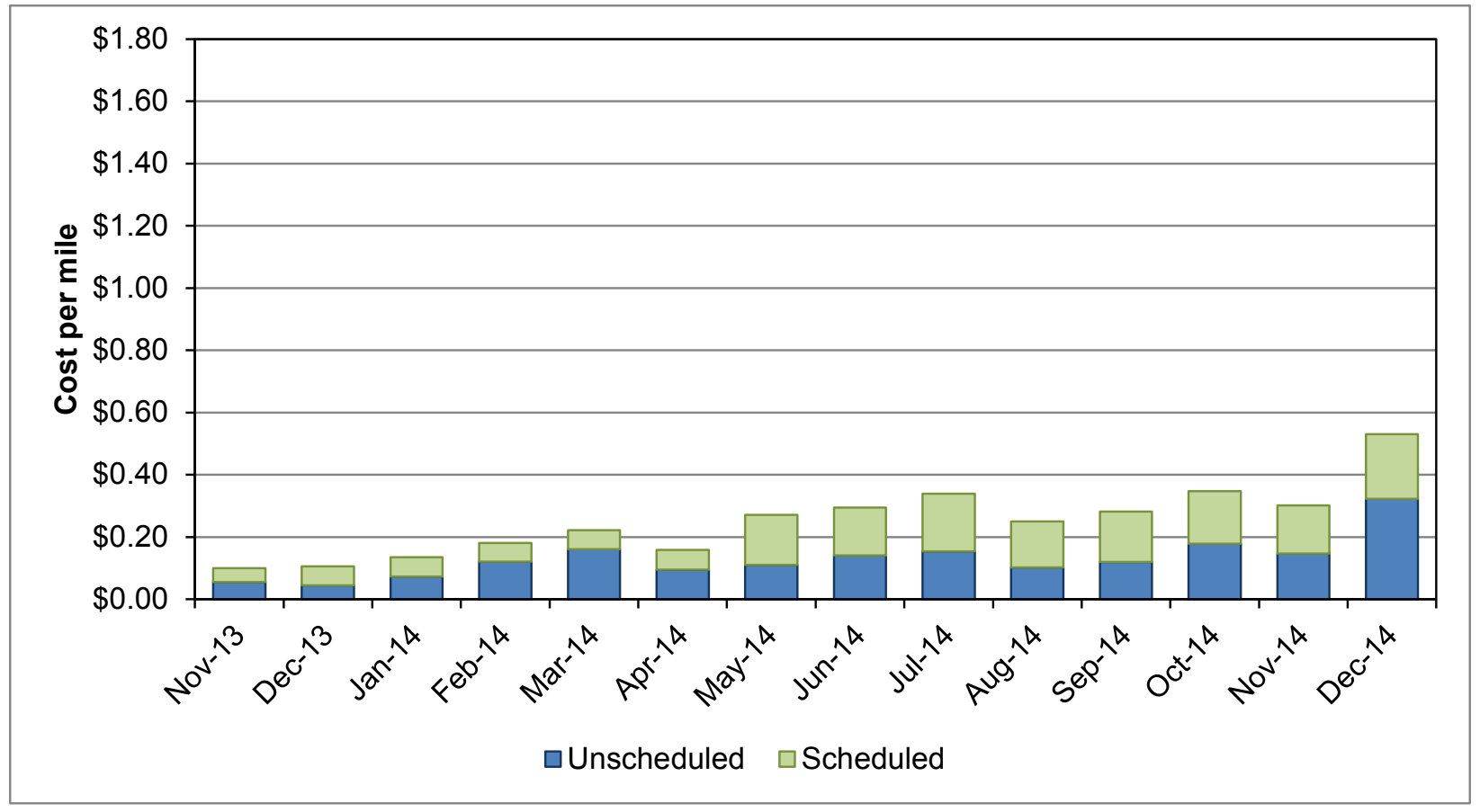

Figure 23. Monthly scheduled and unscheduled costs per mile for the Gillig diesel buses (evaluation period) 


\section{Work Order Maintenance Costs Categorized by System}

Table 12 shows maintenance costs by vehicle system and bus study group (without warranty costs). The table provides the total ZEBA bus costs and the adjusted costs without FC6. The vehicle systems shown in the table are as follows:

- Cab, body, and accessories: Includes body, glass, and paint repairs following accidents; cab and sheet metal repairs on seats and doors; and accessory repairs such as hubodometers and radios

- Propulsion-related systems: Repairs for exhaust, fuel, engine, electric motors, fuel cell modules, propulsion control, non-lighting electrical (charging, cranking, and ignition), air intake, cooling, and transmission

- Preventive maintenance inspections (PMI): Labor for inspections during preventive maintenance

- Brakes

- Frame, steering, and suspension

- Heating, ventilation, and air conditioning (HVAC)

- Lighting

- Air system, general

- Axles, wheels, and drive shaft

- Tires.

Table 12. Work Order Maintenance Cost per Mile by System (Evaluation Period)

\begin{tabular}{|l|c|c|c|c|c|c|c|c|}
\hline \multicolumn{1}{|c|}{ System } & \multicolumn{2}{|c|}{ ZEBA } & \multicolumn{2}{c|}{ ZEBA Adjusted } & \multicolumn{2}{c|}{ Van Hool Diesel } & \multicolumn{2}{|c|}{ Gillig Diesel } \\
\cline { 2 - 9 } & $\begin{array}{c}\text { Cost } \\
\text { per } \\
\text { Mile } \\
(\$)\end{array}$ & $\begin{array}{c}\text { Percent } \\
\text { of Total } \\
(\%)\end{array}$ & $\begin{array}{c}\text { Cost } \\
\text { per } \\
\text { Mile } \\
(\$)\end{array}$ & $\begin{array}{c}\text { Percent } \\
\text { of Total } \\
(\%)\end{array}$ & $\begin{array}{c}\text { Cost } \\
\text { per } \\
\text { Mile } \\
(\$)\end{array}$ & $\begin{array}{c}\text { Percent } \\
\text { of Total } \\
(\%)\end{array}$ & $\begin{array}{c}\text { Cost } \\
\text { per } \\
\text { Mile } \\
(\$)\end{array}$ & $\begin{array}{c}\text { Percent } \\
\text { of Total } \\
(\%)\end{array}$ \\
\hline Propulsion-related & 0.24 & 41 & 0.18 & 37 & 0.18 & 27 & 0.06 & 25 \\
\hline $\begin{array}{l}\text { Cab, body, and } \\
\text { accessories }\end{array}$ & 0.11 & 19 & 0.11 & 22 & 0.17 & 25 & 0.10 & 41 \\
\hline PMl & 0.09 & 16 & 0.09 & 19 & 0.06 & 9 & 0.05 & 21 \\
\hline Brakes & 0.01 & 2 & 0.01 & 3 & 0.08 & 12 & 0.01 & 4 \\
\hline $\begin{array}{l}\text { Frame, steering, and } \\
\text { suspension }\end{array}$ & 0.02 & 4 & 0.02 & 4 & 0.03 & 5 & 0.00 & 1 \\
\hline HVAC & 0.01 & 1 & 0.01 & 2 & 0.07 & 10 & 0.01 & 4 \\
\hline Lighting & 0.01 & 1 & 0.01 & 1 & 0.01 & 2 & 0.00 & 1 \\
\hline Air, general & 0.09 & 15 & 0.06 & 12 & 0.02 & 4 & 0.00 & 1 \\
\hline $\begin{array}{l}\text { Axles, wheels, and } \\
\text { drive shaft }\end{array}$ & 0.00 & 0 & 0.00 & 0 & 0.03 & 5 & 0.00 & 1 \\
\hline Tires & 0.00 & 0 & 0.00 & 0 & 0.00 & 0 & 0.00 & 0 \\
\hline Total & $\mathbf{0 . 5 9}$ & 100 & $\mathbf{0 . 4 9}$ & $\mathbf{1 0 0}$ & $\mathbf{0 . 6 8}$ & 100 & $\mathbf{0 . 2 5}$ & 100 \\
\hline
\end{tabular}

The systems with the highest percentage of maintenance costs for the fuel cell buses were propulsion-related; cab, body, and accessories; and PMI. For the Van Hool diesel buses the 
systems with the highest percentage of maintenance costs were cab, body, and accessories; propulsion-related; and brakes. The Gillig diesel bus systems with the highest percentage of maintenance costs were cab, body, and accessories; propulsion-related; and PMI. Figure 24 shows the monthly cost per mile by category for the ZEBA buses. Appendix D provides additional graphs showing the monthly labor hours and maintenance costs by system for the ZEBA buses and Appendix G provides monthly maintenance graphs for the diesel buses.

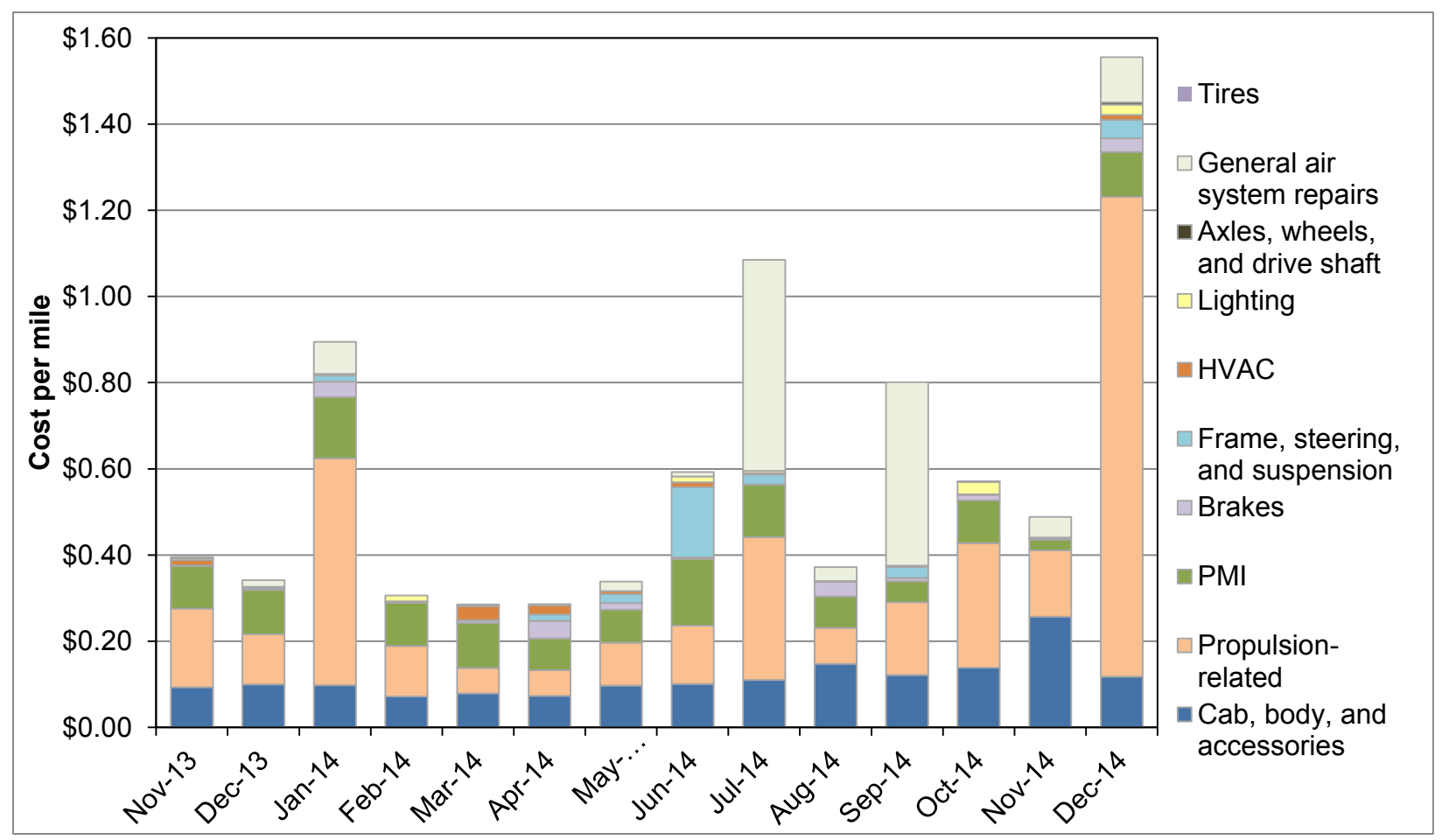

Figure 24. Monthly cost per mile by category for the ZEBA buses (evaluation period)

\section{Propulsion-Related Work Order Maintenance Costs}

Propulsion-related vehicle systems include the exhaust, fuel, engine, electric propulsion, air intake, cooling, non-lighting electrical, and transmission systems. These systems have been separated to highlight maintenance costs most directly affected by the advanced propulsion system changes for the buses. Table 13 shows the propulsion-related system repairs by category for the three study groups during the reporting period. During the data period, the propulsionrelated maintenance costs for the FCEBs were 30\% higher than that of the Van Hool diesel buses. When compared to the new Gillig buses, the FCEBs' propulsion-related maintenance costs were nearly 4 times higher. Removing the FC6 data lowers the propulsion costs for the ZEBA buses to $\$ 0.18$ per mile.

Electric propulsion system maintenance costs accounted for $41 \%$ of the total propulsion cost for the FCEBs. Power plant system repairs accounted for only $15 \%$ of the total propulsion system costs. Issues with the electric drive system (29\% of total propulsion system costs) and the cooling system (26\%) contributed most to the cost. The majority of the propulsion costs for the Van Hool diesel buses were for the exhaust system and cooling system. The majority of the propulsion costs for the Gillig diesel buses were for the power plant. Appendix D and Appendix G provide figures showing the monthly labor and maintenance costs for the propulsion systems by sub-category. 
Table 13. Propulsion-Related Work Order Maintenance Costs by System (Evaluation Period)

\begin{tabular}{|c|c|c|c|c|}
\hline Maintenance System Costs & ZEBA & $\begin{array}{c}\text { ZEBA } \\
\text { Adjusted }\end{array}$ & $\begin{array}{c}\text { Van Hool } \\
\text { Diesel }\end{array}$ & $\begin{array}{l}\text { Gillig } \\
\text { Diesel }\end{array}$ \\
\hline Mileage & 417,757 & 416,833 & 226,166 & 685,681 \\
\hline \multicolumn{5}{|c|}{ Total Propulsion-Related Systems (Roll-up) } \\
\hline Parts cost $(\$)$ & $43,434.68$ & $29,987.75$ & $17,978.67$ & $18,102.44$ \\
\hline Labor hours & $1,130.4$ & 896.3 & 474.4 & 491.3 \\
\hline Total cost $(\$)$ & $99,953.18$ & $74,803.25$ & $41,698.17$ & $42,664.94$ \\
\hline Total cost (\$) per mile & 0.24 & 0.18 & 0.18 & 0.06 \\
\hline \multicolumn{5}{|l|}{ Exhaust System Repairs } \\
\hline Parts cost (\$) & 0.00 & 0.00 & $5,086.94$ & 42.71 \\
\hline Labor hours & 0.0 & 0.0 & 74.8 & 24.2 \\
\hline Total cost $(\$)$ & 0.00 & 0.00 & $8,824.44$ & $1,253.21$ \\
\hline Total cost (\$) per mile & 0.00 & 0.00 & 0.04 & 0.00 \\
\hline \multicolumn{5}{|l|}{ Fuel System Repairs } \\
\hline Parts cost $(\$)$ & 0.00 & 0.00 & $1,303.16$ & $3,313.07$ \\
\hline Labor hours & 79.8 & 57.3 & 32.2 & 31.56 \\
\hline Total cost $(\$)$ & $3,989.00$ & $2,864.00$ & $2,912.66$ & $4,891.07$ \\
\hline Total cost (\$) per mile & 0.01 & 0.01 & 0.01 & 0.01 \\
\hline \multicolumn{5}{|l|}{ Power Plant System Repairs } \\
\hline Parts cost $(\$)$ & 25.00 & 0.00 & $1,578.39$ & $3,278.76$ \\
\hline Labor hours & 296.6 & 247.3 & 115.6 & 132.52 \\
\hline Total cost $(\$)$ & $14,856.00$ & $12,364.50$ & $7,357.39$ & $9,904.76$ \\
\hline Total cost $(\$)$ per mile & 0.04 & 0.03 & 0.03 & 0.01 \\
\hline \multicolumn{5}{|c|}{ Electric Motor and Propulsion Repairs } \\
\hline Parts cost (\$) & $6,462.66$ & 516.12 & 0.00 & 0.00 \\
\hline Labor hours & 443.3 & 306.4 & 0.0 & 0.0 \\
\hline Total cost $(\$)$ & $28,627.16$ & $15,835.12$ & 0.00 & 0.00 \\
\hline Total cost $(\$)$ per mile & 0.07 & 0.04 & 0.00 & 0.00 \\
\hline \multicolumn{5}{|c|}{ Non-Lighting Electrical System Repairs (General Electrical, Charging, Cranking, Ignition) } \\
\hline Parts cost (\$) & $1,586.83$ & 919.83 & 909.86 & $1,880.11$ \\
\hline Labor hours & 72.2 & 64.15 & 37.5 & 110.1 \\
\hline Total cost $(\$)$ & $5,194.33$ & $4,127.33$ & $2,785.86$ & $7,385.11$ \\
\hline Total cost (\$) per mile & 0.01 & 0.01 & 0.01 & 0.01 \\
\hline \multicolumn{5}{|l|}{ Air Intake System Repairs } \\
\hline Parts cost $(\$)$ & $16,415.80$ & $15,889.48$ & $2,921.71$ & $4,012.04$ \\
\hline Labor hours & 97.7 & 95.73 & 51.8 & 55.48 \\
\hline Total cost $(\$)$ & $21,302.30$ & $20,675.98$ & $5,512.21$ & $6,786.04$ \\
\hline Total cost (\$) per mile & 0.05 & 0.05 & 0.02 & 0.01 \\
\hline \multicolumn{5}{|l|}{ Cooling System Repairs } \\
\hline Parts cost $(\$)$ & $18,944.39$ & $12,662.32$ & $5,524.64$ & $4,012.04$ \\
\hline Labor hours & 140.8 & 128.31 & 142.1 & 52.2 \\
\hline Total cost $(\$)$ & $25,984.39$ & $19,077.82$ & $12,627.14$ & $6,622.04$ \\
\hline Total cost (\$) per mile & 0.06 & 0.05 & 0.06 & 0.01 \\
\hline \multicolumn{5}{|l|}{ Transmission Repairs } \\
\hline Parts cost $(\$)$ & 0.00 & 0.00 & 410.67 & 511.04 \\
\hline Labor hours & 0.0 & 0.0 & 16.4 & 76.13 \\
\hline Total cost $(\$)$ & 0.00 & 0.00 & $1,228.17$ & $4,317.54$ \\
\hline Total cost (\$) per mile & 0.00 & 0.00 & 0.01 & 0.01 \\
\hline
\end{tabular}




\section{Total Project Costs}

Throughout the demonstration, the ZEBA buses have incurred some costs that fall outside of the typical maintenance costs reported above. These costs were not included in the analysis presented in the previous maintenance cost sections. The following three activities have been handled primarily by AC Transit's maintenance staff assigned to the FCEBs:

- Research and training: In the early stages of implementing a new technology, it takes time for maintenance staff to learn how to maintain and troubleshoot problems with advanced components and systems. AC Transit tracks these costs as "research and training." These costs have dropped over time as the maintenance staff has become familiar with the technology and taken over more of the maintenance work. During the evaluation period for the report, only 47 hours were attributed to research activities.

- Shuttling FCEBs between depots: For the majority of the demonstration AC Transit has operated the buses out of the Emeryville depot. Because the facility did not have a maintenance bay that was equipped to allow work on a hydrogen-fueled bus, AC Transit staff had to shuttle the buses to the Oakland depot where there is a maintenance bay outfitted for the FCEBs. This added to the labor costs for the buses and is tracked separately in the work orders. The agency is currently retrofitting one of the Emeryville maintenance bays similar to what was done at the Oakland depot. Once the retrofit is complete, this activity will no longer be necessary. Occasionally, the baseline diesel buses were also shuttled from one depot to another for maintenance repair. For a fair comparison, NREL also removed the costs for shuttling the diesel buses from the analysis.

- Fueling and cleaning: In the early stage of the demonstration, AC Transit had maintenance staff assigned specifically to the FCEBs for fueling and cleaning the buses. These activities for buses at a depot are typically handled by different staff during the evenings when all buses are prepared for the next morning pullout. Over the evaluation period for the report, the FCEBs have been worked into the overall process. There were only 20 hours attributed to this activity and they occurred during the first two months of the evaluation period.

These costs are considered non-recurring costs for the FCEBs; however, they add to the current cost per mile of the ZEBA buses.

Table 14 shows the breakdown of these costs and how they affect the total cost per mile of the project. The table shows the non-recurring costs during three periods to show the decrease over time. The first time period was during the extended hydrogen station downtime (as described in the previous report) when the buses were not operating and therefore not accumulating miles. The second period was the evaluation period from the previous report, and the third is the evaluation period that is the focus of this report. The non-recurring costs for the ZEBA fleet have dropped dramatically over the last year and add only $\$ 0.05$ per mile to the operating cost of the buses for the evaluation period in this report. Once the Emeryville maintenance bay is completed, these costs should be completely eliminated. 
Table 14. Maintenance Costs Including Non-Recurring Labor

\begin{tabular}{|l|r|r|r|r|}
\hline & Mileage & $\begin{array}{l}\text { Labor } \\
\text { Hours }\end{array}$ & $\begin{array}{l}\text { Total } \\
\text { Cost }\end{array}$ & $\begin{array}{l}\text { Cost per } \\
\text { Mile }\end{array}$ \\
\hline Station Downtime Period (May 2012-Feb 2013) \\
\hline Shuttle FCEBs & 19,296 & 118.5 & 5,925 & 0.31 \\
\hline Research/training & 19,296 & 1,703 & 85,169 & 4.41 \\
\hline Fuel and clean & 19,296 & 908 & 45,412 & 2.35 \\
\hline Total & $\mathbf{1 9 , 2 9 6}$ & $\mathbf{2 , 7 3 0}$ & $\mathbf{1 3 6 , 5 0 6}$ & $\mathbf{7 . 0 7}$ \\
\hline Evaluation Period (Mar 2013-Oct 2013) \\
\hline Shuttle FCEBs & 259,065 & 211 & 10,537 & 0.04 \\
\hline Research/training & 259,065 & 321 & 16,075 & 0.06 \\
\hline Fuel and clean & 259,065 & 75 & 3,765 & 0.01 \\
\hline Total & $\mathbf{2 5 9 , 0 6 5}$ & $\mathbf{6 0 8}$ & $\mathbf{3 0 , 3 7 6}$ & $\mathbf{0 . 1 2}$ \\
\hline Evaluation Period (Nov 2013-Dec 2014) \\
\hline Shuttle FCEBs & 417,757 & 332 & 16,597 & 0.04 \\
\hline Research/training & 417,757 & 47 & 2,350 & 0.01 \\
\hline Fuel and clean & 417,757 & 20 & 975 & 0.00 \\
\hline Total & $\mathbf{4 1 7 , 7 5 7}$ & $\mathbf{3 9 8}$ & $\mathbf{1 9 , 9 2 2}$ & $\mathbf{0 . 0 5}$ \\
\hline
\end{tabular}

Costs for AC Transit's extended warranty agreements with US Hybrid and EnerDel began in April 2014. While the cost for these agreements is covered through the FTA grant, other interested agencies should understand the current costs for FCEBs outside the initial warranty period. Table 15 summarizes the total costs for the ZEBA and diesel baseline buses including the extra labor and extended warranty during the evaluation period. The cost for shuttling the diesel buses between depots adds less than one cent to the total cost per mile.

Table 15. Total Maintenance Cost per Mile Including Extra Labor and Extended Warranty (Evaluation Period)

\begin{tabular}{|l|c|c|c|}
\hline & ZEBA & Van Hool & Gillig \\
\hline Maintenance labor hours & $3,013.6$ & $1,921.7$ & $2,669.7$ \\
\hline Extra labor hours & 398.4 & 4.0 & 25.9 \\
\hline Total labor hours & $3,412.1$ & $1,925.7$ & $2,695.7$ \\
\hline Total parts cost & $\$ 95,264$ & $\$ 57,556$ & $\$ 35,836$ \\
\hline Extended warranty cost & $\$ 287,790$ & - & - \\
\hline Total cost per mile & $\$ 1.33$ & $\$ 0.68$ & $\$ 0.25$ \\
\hline
\end{tabular}




\section{What's Next for ZEBA}

AC Transit's plans for the ZEBA demonstration are to continue operating four buses out of the Emeryville Division and eight buses at the Oakland Division. NREL will continue to evaluate the buses and will collect data and experience from the other operators should they decide to put the buses in service. 


\section{Contacts}

\section{DOE}

1000 Independence Ave., SW

Washington, DC 20585

Jason Marcinkoski, Technology

Development Manager, Fuel Cell

Technologies Office

Phone: 202-586-7466

Email: jason.marcinkoski@ee.doe.gov

NREL

15013 Denver West Parkway

Golden, CO 80401

Leslie Eudy, Senior Project Leader

Phone: 303-275-4412

Email: leslie.eudy@,nrel.gov

\section{AC Transit}

1700 Franklin Street

Oakland, CA 94612

Salvador Llamas, Director of Maintenance

Phone: 510-577-8803

Email: sllamas@actransit.org

\section{US Hybrid Corporation}

445 Maple Avenue

Torrance, CA 90503

Reza Sarhadi-Nia, Fuel Cell Service and

Support

Phone: 310-212-1200, Ext. 127

Email: reza@ushybrid.com

\section{EnerDel Inc.}

15425 Herriman Blvd.

Noblesville, IN 46060

Tomasz Posnar, Vice President, Transportation and Aftermarket

Phone: 954-401-0338

Email: tomasz.poznar@enerdel.com

\section{Van Hool}

Bernard Van Hoolstraat 58

B-2500 Lier Koningshooikt, Belgium

Paul Jenné, Automotive Relations

Phone: +32 (3) 4202210

Email: paul.jenne@,vanhool.be

\section{Linde, LLC}

2389 Lincoln Avenue

Hayward, CA 94545

Nitin Natesan, Engineering Manager, Alternative Energy Projects

Phone: 510-786-5931

Email: nitin.natesan@lindeus.com 


\section{References and Related Reports}

All NREL hydrogen and fuel cell-related evaluation reports can be downloaded from the following website: www.nrel.gov/hydrogen/proj_fc bus_eval.html.

\section{AC Transit}

Eudy, L.; Post, M. (2014). Zero Emission Bay Area (ZEBA) Fuel Cell Bus Demonstration Results: Third Report. NREL/TP-5400-60527. Golden, CO: National Renewable Energy Laboratory.

Eudy, L.; Chandler, K. (2012). Zero Emission Bay Area (ZEBA) Fuel Cell Bus Demonstration: Second Results Report. NREL/TP-5600-55367. Golden, CO: National Renewable Energy Laboratory.

Chandler, K.; Eudy, L. (2011). Zero Emission Bay Area (ZEBA) Fuel Cell Bus Demonstration: First Results Report. NREL/TP-5600-52015. Golden, CO: National Renewable Energy Laboratory.

\section{General}

Eudy, L.; Post, M.; Gikakis, C. (2014). Fuel Cell Buses in U.S. Transit Fleets: Current Status 2014. NREL/TP-5400-62683. Golden, CO: National Renewable Energy Laboratory.

Eudy, L.; Gikakis, C. (2013). Fuel Cell Buses in U.S. Transit Fleets: Current Status 2013. NREL/TP-5400-60490. Golden, CO: National Renewable Energy Laboratory.

Chandler, K.; Eudy, L. (2012). FTA Fuel Cell Bus Program: Research Accomplishments through 2011. FTA Report No. 0014. Washington, DC: Federal Transit Administration.

Eudy, L. (2010). Fuel Cell Transit Bus Evaluations, Joint Evaluation Plan for the U.S. Department of Energy and the Federal Transit Administration. NREL/TP-560-49342. Golden, CO: National Renewable Energy Laboratory. 


\section{Appendix A: TRL Guideline Table}

\section{Technology Readiness Levels for FCEB Commercialization}

\begin{tabular}{|c|c|c|c|}
\hline $\begin{array}{l}\text { Relative Level } \\
\text { of Technology } \\
\text { Development }\end{array}$ & $\begin{array}{l}\text { Technology } \\
\text { Readiness } \\
\text { Level }\end{array}$ & TRL Definition & Description \\
\hline Deployment & TRL 9 & $\begin{array}{l}\text { Actual system } \\
\text { operated over the full } \\
\text { range of expected } \\
\text { conditions }\end{array}$ & $\begin{array}{l}\text { The technology is in its final form. } \\
\text { Deployment, marketing, and support begin for } \\
\text { the first fully commercial products. }\end{array}$ \\
\hline \multirow{3}{*}{$\begin{array}{l}\text { Technology } \\
\text { Demonstration/ } \\
\text { Commissioning }\end{array}$} & TRL 8 & $\begin{array}{l}\text { Actual system } \\
\text { completed and } \\
\text { qualified through test } \\
\text { and demonstration }\end{array}$ & $\begin{array}{l}\text { The last step in true system development. } \\
\text { Demonstration of a limited production of } 50 \text { to } \\
100 \text { buses at a small number of locations. } \\
\text { Beginning the transition of all maintenance to } \\
\text { transit staff. }\end{array}$ \\
\hline & TRL 7 & $\begin{array}{l}\text { Full-scale validation in } \\
\text { relevant environment }\end{array}$ & $\begin{array}{l}\text { A major step up from TRL } 6 \text { by adding larger } \\
\text { numbers of buses and increasing the hours of } \\
\text { service. Full-scale demonstration and } \\
\text { reliability testing of } 5 \text { to } 10 \text { buses at several } \\
\text { locations. Manufacturers begin to train larger } \\
\text { numbers of transit staff in operation and } \\
\text { maintenance. }\end{array}$ \\
\hline & TRL 6 & $\begin{array}{l}\text { Engineering/pilot-scale } \\
\text { validation in relevant } \\
\text { environment }\end{array}$ & $\begin{array}{l}\text { First tests of prototype buses in actual transit } \\
\text { service. Field testing and design shakedown } \\
\text { of one to two prototypes. Manufacturers assist } \\
\text { in operation and typically handle all } \\
\text { maintenance. Begin to introduce transit staff to } \\
\text { technology. }\end{array}$ \\
\hline \multirow{2}{*}{$\begin{array}{l}\text { Technology } \\
\text { Development }\end{array}$} & TRL 5 & $\begin{array}{l}\text { Laboratory scale, } \\
\text { similar system } \\
\text { validation in relevant } \\
\text { environment }\end{array}$ & $\begin{array}{l}\text { Integrated system is tested in a laboratory } \\
\text { under simulated conditions based on early } \\
\text { modeling. System is integrated into an early } \\
\text { prototype or mule platform for some on-road } \\
\text { testing. }\end{array}$ \\
\hline & TRL 4 & $\begin{array}{l}\text { Component and } \\
\text { system validation in } \\
\text { laboratory environment }\end{array}$ & $\begin{array}{l}\text { Basic technological components are } \\
\text { integrated into the system and begin } \\
\text { laboratory testing and modeling of potential } \\
\text { duty cycles. }\end{array}$ \\
\hline \multirow[t]{2}{*}{$\begin{array}{l}\text { Research to } \\
\text { Prove } \\
\text { Feasibility }\end{array}$} & TRL 3 & $\begin{array}{c}\text { Analytical and } \\
\text { experimental critical } \\
\text { function and/or proof of } \\
\text { concept }\end{array}$ & $\begin{array}{l}\text { Active research into components and system } \\
\text { integration needs. Investigate what } \\
\text { requirements might be met with existing } \\
\text { commercial components. }\end{array}$ \\
\hline & TRL 2 & $\begin{array}{l}\text { Technology concept } \\
\text { and/or application } \\
\text { formulated }\end{array}$ & $\begin{array}{l}\text { Research technology needed to meet market } \\
\text { requirements. Define strategy for moving } \\
\text { through development stages. }\end{array}$ \\
\hline $\begin{array}{l}\text { Basic } \\
\text { Technology } \\
\text { Research }\end{array}$ & TRL 1 & $\begin{array}{c}\text { Basic principles } \\
\text { observed and reported }\end{array}$ & $\begin{array}{l}\text { Scientific research and early development of } \\
\text { FCEB concepts. }\end{array}$ \\
\hline
\end{tabular}




\section{Appendix B: ZEBA Fleet Summary Statistics}

\section{ZEBA Fleet Operations and Economics}

\begin{tabular}{|c|c|c|c|c|}
\hline & $\begin{array}{c}\text { ZEBA } \\
9 / 11-4 / 12 \\
\text { (Early } \\
\text { Service) }\end{array}$ & $\begin{array}{c}\text { ZEBA } \\
\text { 5/12-2/13 } \\
\text { (Station } \\
\text { Downtime } \\
\text { Period ) }\end{array}$ & $\begin{array}{c}\text { ZEBA } \\
3 / 13-12 / 14 \\
\text { Data Period }\end{array}$ & $\begin{array}{c}\text { ZEBA } \\
\text { 11/13-12/14 } \\
\text { (Report } \\
\text { Evaluation } \\
\text { Period ) }\end{array}$ \\
\hline Number of vehicles & 12 & 12 & 12 & 12 \\
\hline Period used for fuel and oil op analysis & $9 / 11-4 / 12$ & $5 / 12-2 / 13$ & $3 / 13-12 / 14$ & $11 / 13-12 / 14$ \\
\hline Total number of months in period & 8 & 10 & 22 & 14 \\
\hline Fuel and oil analysis base fleet mileage & 120,355 & 16,281 & 632,444 & 384,060 \\
\hline Period used for maintenance op analysis & $9 / 11-4 / 12$ & $5 / 12-2 / 13$ & $3 / 13-12 / 14$ & $11 / 13-12 / 14$ \\
\hline Total number of months in period & 8 & 10 & 22 & 14 \\
\hline Maintenance analysis base fleet mileage & 147,129 & 19,296 & 676,822 & 417,757 \\
\hline Average monthly mileage per vehicle & 1,598 & - & 2,564 & 2,487 \\
\hline Availability & $56 \%$ & 一 & $75 \%$ & $72 \%$ \\
\hline Fleet fuel usage $\left(\mathrm{H}_{2}\right.$ in $\mathrm{kg} /$ diesel in gallons $)$ & $18,016.0$ & $2,125.2$ & $98,633.1$ & $59,986.3$ \\
\hline Total roadcalls & 73 & - & 113 & 67 \\
\hline MBRC - all systems & 2,014 & 一 & 5,990 & 6,235 \\
\hline Propulsion roadcalls & 49 & - & 68 & 40 \\
\hline Propulsion MBRC & 3,000 & - & 9,953 & 10,444 \\
\hline Fleet miles/kg hydrogen $\left(1.13 \mathrm{~kg} \mathrm{H} \mathrm{H}_{2}\right)$ & 6.68 & 7.66 & 6.41 & 6.40 \\
\hline Representative fleet MPG (energy equiv) & 7.55 & 8.66 & 7.25 & 7.23 \\
\hline Hydrogen cost per kg & 9.34 & 8.47 & 9.09 & 9.10 \\
\hline Fuel cost per mile & 1.40 & 1.11 & 1.42 & 1.42 \\
\hline Total scheduled repair cost per mile & 0.26 & 0.08 & 0.17 & 0.18 \\
\hline Total unscheduled repair cost per mile & 1.05 & 2.91 & 0.45 & 0.41 \\
\hline Total maintenance cost per mile & 1.31 & 3.00 & 0.62 & 0.59 \\
\hline Total operating cost per mile & 2.71 & 4.10 & 2.04 & 2.01 \\
\hline $\begin{array}{l}\text { Extended Warranty cost (beginning in April } \\
\text { 2014) }\end{array}$ & & & $\$ 287,790$ & $\$ 287,790$ \\
\hline Extra labor costs per mile (research, shuttling) & 0.27 & 7.07 & 0.07 & 0.05 \\
\hline $\begin{array}{l}\text { Total operating cost per mile (incl. warranty } \\
\text { and extra costs) }\end{array}$ & 2.98 & 11.24 & 2.53 & 2.75 \\
\hline
\end{tabular}

Maintenance Costs

\begin{tabular}{|l|r|r|r|r|}
\hline & \multicolumn{1}{|c|}{$\begin{array}{c}\text { ZEBA } \\
9 / 11-4 / 12 \\
\text { (Early } \\
\text { Service) }\end{array}$} & $\begin{array}{c}\text { ZEBA } \\
\text { 5/12-2/13 } \\
\text { (Station } \\
\text { Downtime } \\
\text { Period })\end{array}$ & $\begin{array}{r}\text { ZEBA } \\
\text { 3/13-12/14 } \\
\text { Data Period }\end{array}$ & $\begin{array}{r}\text { ZEBA } \\
11 / 13-12 / 14 \\
\text { (Report } \\
\text { Evaluation } \\
\text { Period })\end{array}$ \\
\hline Fleet mileage & 147,007 & 19,296 & 676,822 & 417,757 \\
\hline Total parts cost & $31,727.9$ & $9,854.4$ & $139,781.4$ & $95,264.1$ \\
\hline Total labor hours & $3,219.70$ & 960.1 & $5,532.0$ & $3,013.6$ \\
\hline Average labor cost (@ \$50.00 per hour) & $160,985.00$ & $48,005.00$ & $276,600.00$ & $150,681.00$ \\
\hline Total maintenance cost & $192,712.88$ & $57,859.44$ & $416,381.43$ & $245,945.05$ \\
\hline Total maintenance cost per bus & $16,059.41$ & $4,821.62$ & $34,698.45$ & $20,495.42$ \\
\hline Total maintenance cost per mile & $\mathbf{1 . 3 1}$ & $\mathbf{3 . 0 0}$ & $\mathbf{0 . 6 2}$ & $\mathbf{0 . 5 9}$ \\
\hline
\end{tabular}


Breakdown of Maintenance Costs by Vehicle System

\begin{tabular}{|c|c|c|c|c|}
\hline & $\begin{array}{c}\text { ZEBA } \\
9 / 11-4 / 12 \\
\text { (Early } \\
\text { Service) }\end{array}$ & $\begin{array}{c}\text { ZEBA } \\
\text { 5/12-2/13 } \\
\text { (Station } \\
\text { Downtime } \\
\text { Period) }\end{array}$ & $\begin{array}{c}\text { ZEBA } \\
\text { 3/13-12/14 } \\
\text { Data Period }\end{array}$ & $\begin{array}{c}\text { ZEBA } \\
\text { 11/13-12/14 } \\
\text { (Report } \\
\text { Evaluation } \\
\text { Period ) }\end{array}$ \\
\hline Fleet mileage & 147,007 & 19,296 & 676,822 & 417,757 \\
\hline \multicolumn{5}{|c|}{ Total Engine/Fuel-Related Systems (ATA VMRS 27, 30, 31, 32, 33, 41, 42, 43, 44, 45, 46, 65) } \\
\hline Parts cost & $5,957.71$ & $8,597.79$ & $78,177.83$ & $43,434.68$ \\
\hline Labor hours & $1,012.7$ & 611.9 & $2,211.0$ & $1,130.4$ \\
\hline Average labor cost & $50,633.50$ & $30,595.50$ & $110,550.00$ & $56,518.50$ \\
\hline Total cost (for system) & $56,591.21$ & $39,193.29$ & $188,727.83$ & $99,953.18$ \\
\hline Total cost (for system) per bus & $4,715.93$ & $3,266.11$ & $15,727.32$ & $8,329.43$ \\
\hline Total cost (for system) per mile & 0.38 & 2.03 & 0.28 & 0.24 \\
\hline \multicolumn{5}{|c|}{ Exhaust System Repairs (ATA VMRS 43) } \\
\hline Parts cost & 0.00 & 0.00 & 0.00 & 0.00 \\
\hline Labor hours & 0.0 & 0.0 & 0.0 & 0.0 \\
\hline Average labor cost & 0.00 & 0.00 & 0.00 & 0.00 \\
\hline Total cost (for system) & 0.00 & 0.00 & 0.00 & 0.00 \\
\hline Total cost (for system) per bus & 0.00 & 0.00 & 0.00 & 0.00 \\
\hline Total cost (for system) per mile & 0.00 & 0.00 & 0.00 & 0.00 \\
\hline \multicolumn{5}{|c|}{ Fuel System Repairs (ATA VMRS 44) } \\
\hline Parts cost & 15.47 & 0.00 & 26.75 & 0.00 \\
\hline Labor hours & 166.7 & 30.4 & 161.6 & 79.8 \\
\hline Average labor cost & $8,335.00$ & $1,520.50$ & $8,080.50$ & $3,989.00$ \\
\hline Total cost (for system) & $8,350.47$ & $1,520.50$ & $8,107.25$ & $3,989.00$ \\
\hline Total cost (for system) per bus & 695.87 & 126.71 & 675.60 & 332.42 \\
\hline Total cost (for system) per mile & 0.06 & 0.08 & 0.01 & 0.01 \\
\hline \multicolumn{5}{|c|}{ Power Plant (Engine) Repairs (ATA VMRS 45) } \\
\hline Parts cost & 260.89 & 145.88 & 259.96 & 25.00 \\
\hline Labor hours & 204.0 & 172.1 & 590.8 & 296.6 \\
\hline Average labor cost & $10,200.50$ & $8,606.50$ & $29,538.50$ & $14,831.00$ \\
\hline Total cost (for system) & $10,461.39$ & $8,752.38$ & $29,798.46$ & $14,856.00$ \\
\hline Total cost (for system) per bus & 871.78 & 729.37 & $2,483.21$ & $1,238.00$ \\
\hline Total cost (for system) per mile & 0.07 & 0.45 & 0.04 & 0.04 \\
\hline \multicolumn{5}{|c|}{ Electric Propulsion Repairs (ATA VMRS 46) } \\
\hline Parts cost & $1,251.77$ & 0.00 & $26,048.55$ & $6,462.66$ \\
\hline Labor hours & 458.5 & 313.3 & 830.4 & 443.3 \\
\hline Average labor cost & $22,924.00$ & $15,663.00$ & $41,520.00$ & $22,164.50$ \\
\hline Total cost (for system) & $24,175.77$ & $15,663.00$ & $67,568.55$ & $28,627.16$ \\
\hline Total cost (for system) per bus & $2,014.65$ & $1,305.25$ & $5,630.71$ & $2,385.60$ \\
\hline Total cost (for system) per mile & 0.16 & 0.81 & 0.10 & 0.07 \\
\hline
\end{tabular}


Breakdown of Maintenance Costs by Vehicle System (continued)

\begin{tabular}{|c|c|c|c|c|}
\hline & $\begin{array}{c}\text { ZEBA } \\
9 / 11-4 / 12 \\
\text { (Early } \\
\text { Service) }\end{array}$ & $\begin{array}{c}\text { ZEBA } \\
\text { 5/12-2/13 } \\
\text { (Station } \\
\text { Downtime } \\
\text { Period) }\end{array}$ & $\begin{array}{c}\text { ZEBA } \\
\text { 3/13-12/14 } \\
\text { Data Period }\end{array}$ & $\begin{array}{c}\text { ZEBA } \\
\text { 11/13-12/14 } \\
\text { (Report } \\
\text { Evaluation } \\
\text { Period ) }\end{array}$ \\
\hline \multicolumn{5}{|c|}{ Electrical System Repairs (ATA VMRS 30-Electrical General, 31-Charging, 32-Cranking, 33-Ignition) } \\
\hline Parts cost & $1,747.91$ & 2023.98 & 3675.76 & 1586.83 \\
\hline Labor hours & 81.3 & 33.7 & 125.9 & 72.2 \\
\hline Average labor cost & $4,064.50$ & $1,687.00$ & $6,293.50$ & $3,607.50$ \\
\hline Total cost (for system) & $5,812.41$ & $3,710.98$ & $9,969.26$ & $5,194.33$ \\
\hline Total cost (for system) per bus & 484.37 & 309.25 & 830.77 & 432.86 \\
\hline Total cost (for system) per mile & 0.04 & 0.19 & 0.01 & 0.01 \\
\hline \multicolumn{5}{|c|}{ Air Intake System Repairs (ATA VMRS 41) } \\
\hline Parts cost & $2,152.28$ & 6096.88 & 25288.54 & 16415.80 \\
\hline Labor hours & 8.7 & 13.6 & 271.9 & 97.7 \\
\hline Average labor cost & 435.50 & 678.00 & $13,594.50$ & $4,886.50$ \\
\hline Total cost (for system) & $2,587.78$ & $6,774.88$ & $38,883.04$ & $21,302.30$ \\
\hline Total cost (for system) per bus & 215.65 & 564.57 & $3,240.25$ & $1,775.19$ \\
\hline Total cost (for system) per mile & 0.02 & 0.35 & 0.06 & 0.05 \\
\hline \multicolumn{5}{|c|}{ Cooling System Repairs (ATA VMRS 42) } \\
\hline Parts cost & 529.39 & 331.06 & 22878.26 & 18944.39 \\
\hline Labor hours & 93.5 & 48.8 & 230.5 & 140.8 \\
\hline Average labor cost & $4,674.00$ & $2,440.50$ & $11,523.00$ & $7,040.00$ \\
\hline Total cost (for system) & $5,203.39$ & $2,771.56$ & $34,401.26$ & $25,984.39$ \\
\hline Total cost (for system) per bus & 433.62 & 230.96 & $2,866.77$ & $2,165.37$ \\
\hline Total cost (for system) per mile & 0.04 & 0.14 & 0.05 & 0.06 \\
\hline \multicolumn{5}{|c|}{ Hydraulic System Repairs (ATA VMRS 65) } \\
\hline Parts cost & 0.00 & 0.00 & 0.00 & 0.00 \\
\hline Labor hours & 0.0 & 0.0 & 0.0 & 0.0 \\
\hline Average labor cost & 0.00 & 0.00 & 0.00 & 0.00 \\
\hline Total cost (for system) & 0.00 & 0.00 & 0.00 & 0.00 \\
\hline Total cost (for system) per bus & 0.00 & 0.00 & 0.00 & 0.00 \\
\hline Total cost (for system) per mile & 0.00 & 0.00 & 0.00 & 0.00 \\
\hline \multicolumn{5}{|c|}{ General Air System Repairs (ATA VMRS 10) } \\
\hline Parts cost & $3,875.75$ & 0.00 & 34937.74 & 32040.70 \\
\hline Labor hours & 66.4 & 10.3 & 146.0 & 101.0 \\
\hline Average labor cost & $3,321.50$ & 516.00 & $7,299.00$ & $5,049.00$ \\
\hline Total cost (for system) & $7,197.25$ & 516.00 & $42,236.74$ & $37,089.70$ \\
\hline Total cost (for system) per bus & 599.77 & 43.00 & $3,519.73$ & $3,090.81$ \\
\hline Total cost (for system) per mile & 0.05 & 0.03 & 0.06 & 0.09 \\
\hline
\end{tabular}


Breakdown of Maintenance Costs by Vehicle System (continued)

\begin{tabular}{|c|c|c|c|c|}
\hline & $\begin{array}{c}\text { ZEBA } \\
9 / 11-4 / 12 \\
\text { (Early } \\
\text { Service) }\end{array}$ & $\begin{array}{c}\text { ZEBA } \\
\text { 5/12-2/13 } \\
\text { (Station } \\
\text { Downtime } \\
\text { Period ) }\end{array}$ & $\begin{array}{c}\text { ZEBA } \\
\text { 3/13-12/14 } \\
\text { Data Period }\end{array}$ & $\begin{array}{c}\text { ZEBA } \\
\text { 11/13-12/14 } \\
\text { (Report } \\
\text { Evaluation } \\
\text { Period) }\end{array}$ \\
\hline \multicolumn{5}{|c|}{ Brake System Repairs (ATA VMRS 13) } \\
\hline Parts cost & 321.45 & 0.00 & 2729.83 & 2395.83 \\
\hline Labor hours & 24.0 & 0.0 & 117.9 & 65.9 \\
\hline Average labor cost & $1,200.00$ & 0.00 & $5,897.00$ & $3,297.00$ \\
\hline Total cost (for system) & $1,521.45$ & 0.00 & $8,626.83$ & $5,692.83$ \\
\hline Total cost (for system) per bus & 126.79 & 0.00 & 718.90 & 474.40 \\
\hline Total cost (for system) per mile & 0.01 & 0.00 & 0.01 & 0.01 \\
\hline \multicolumn{5}{|c|}{ Transmission Repairs (ATA VMRS 27) } \\
\hline Parts cost & 0.00 & 0.00 & 0.00 & 0.00 \\
\hline Labor hours & 0.0 & 0.0 & 0.0 & 0.0 \\
\hline Average labor cost & 0.00 & 0.00 & 0.00 & 0.00 \\
\hline Total cost (for system) & 0.00 & 0.00 & 0.00 & 0.00 \\
\hline Total cost (for system) per bus & 0.00 & 0.00 & 0.00 & 0.00 \\
\hline Total cost (for system) per mile & 0.00 & 0.00 & 0.00 & 0.00 \\
\hline \multicolumn{5}{|c|}{ Inspections Only - no parts replacements (101) } \\
\hline Parts cost & 0.00 & 0.00 & 0.00 & 0.00 \\
\hline Labor hours & 669.0 & 19.5 & $1,239.6$ & 788.1 \\
\hline Average labor cost & $33,449.50$ & 975.00 & $61,980.50$ & $39,404.00$ \\
\hline Total cost (for system) & $33,449.50$ & 975.00 & $61,980.50$ & $39,404.00$ \\
\hline Total cost (for system) per bus & $2,787.46$ & 81.25 & $5,165.04$ & $3,283.67$ \\
\hline Total cost (for system) per mile & 0.23 & 0.05 & 0.09 & 0.09 \\
\hline \multicolumn{5}{|c|}{$\begin{array}{l}\text { Cab, Body, and Accessories Systems Repairs (ATA VMRS 02-Cab and Sheet Metal, 50-Accessories, } \\
\text { 71-Body) }\end{array}$} \\
\hline Parts cost & $18,550.84$ & 1120.55 & 10735.34 & 8611.04 \\
\hline Labor hours & $1,281.2$ & 257.9 & $1,475.5$ & 786.9 \\
\hline Average labor cost & $64,059.00$ & $12,896.50$ & $73,775.00$ & $39,344.50$ \\
\hline Total cost (for system) & $82,609.84$ & $14,017.05$ & $84,510.34$ & $47,955.54$ \\
\hline Total cost (for system) per bus & $6,884.15$ & $1,168.09$ & $7,042.53$ & $3,996.29$ \\
\hline Total cost (for system) per mile & 0.56 & 0.73 & 0.12 & 0.11 \\
\hline \multicolumn{5}{|c|}{ HVAC System Repairs (ATA VMRS 01) } \\
\hline Parts cost & 897.40 & 0.00 & 3129.51 & 1320.35 \\
\hline Labor hours & 14.7 & 5.0 & 105.8 & 39.0 \\
\hline Average labor cost & 735.00 & 249.00 & $5,291.50$ & $1,950.00$ \\
\hline Total cost (for system) & $1,632.40$ & 249.00 & $8,421.01$ & $3,270.35$ \\
\hline Total cost (for system) per bus & 136.03 & 20.75 & 701.75 & 272.53 \\
\hline Total cost (for system) per mile & 0.01 & 0.01 & 0.01 & 0.01 \\
\hline
\end{tabular}


Breakdown of Maintenance Costs by Vehicle System (continued)

\begin{tabular}{|c|c|c|c|c|}
\hline & $\begin{array}{c}\text { ZEBA } \\
9 / 11-4 / 12 \\
\text { (Early } \\
\text { Service) }\end{array}$ & $\begin{array}{c}\text { ZEBA } \\
\text { 5/12-2/13 } \\
\text { (Station } \\
\text { Downtime } \\
\text { Period ) }\end{array}$ & $\begin{array}{c}\text { ZEBA } \\
\text { 3/13-12/14 } \\
\text { Data Period }\end{array}$ & $\begin{array}{c}\text { ZEBA } \\
\text { 11/13-12/14 } \\
\text { (Report } \\
\text { Evaluation } \\
\text { Period ) }\end{array}$ \\
\hline \multicolumn{5}{|c|}{ Lighting System Repairs (ATA VMRS 34) } \\
\hline Parts cost & 290.00 & 27.62 & 1317.14 & 330.30 \\
\hline Labor hours & 24.4 & 3.3 & 82.0 & 51.5 \\
\hline Average labor cost & $1,220.50$ & 165.50 & $4,099.50$ & $2,577.00$ \\
\hline Total cost (for system) & $1,510.50$ & 193.12 & $5,416.64$ & $2,907.30$ \\
\hline Total cost (for system) per bus & 125.88 & 16.09 & 451.39 & 242.28 \\
\hline Total cost (for system) per mile & 0.01 & 0.01 & 0.01 & 0.01 \\
\hline \multicolumn{5}{|c|}{ Frame, Steering, and Suspension Repairs (ATA VMRS 14-Frame, 15-Steering, 16-Suspension) } \\
\hline Parts cost & $1,751.91$ & 108.48 & 8751.43 & 7131.14 \\
\hline Labor hours & 103.2 & 52.2 & 139.7 & 46.3 \\
\hline Average labor cost & $5,161.00$ & $2,607.50$ & $6,982.50$ & $2,316.00$ \\
\hline Total cost (for system) & $6,912.91$ & $2,715.98$ & $15,733.93$ & $9,447.14$ \\
\hline Total cost (for system) per bus & 576.08 & 226.33 & $1,311.16$ & 787.26 \\
\hline Total cost (for system) per mile & 0.05 & 0.14 & 0.02 & 0.02 \\
\hline \multicolumn{5}{|c|}{$\begin{array}{l}\text { Axle, Wheel, and Drive Shaft Repairs (ATA VMRS 11-Front Axle, 18-Wheels, 22-Rear Axle, 24-Drive } \\
\text { Shaft) }\end{array}$} \\
\hline Parts cost & 5.48 & 0.00 & 2.61 & 0.00 \\
\hline Labor hours & 22.6 & 0.0 & 13.5 & 4.5 \\
\hline Average labor cost & $1,131.50$ & 0.00 & 675.00 & 225.00 \\
\hline Total cost (for system) & $1,136.98$ & 0.00 & 677.61 & 225.00 \\
\hline Total cost (for system) per bus & 94.75 & 0.00 & 56.47 & 18.75 \\
\hline Total cost (for system) per mile & 0.01 & 0.00 & 0.00 & 0.00 \\
\hline \multicolumn{5}{|l|}{ Tire Repairs (ATA VMRS 17) } \\
\hline Parts cost & 0.00 & 0.00 & 0.00 & 0.00 \\
\hline Labor hours & 0.0 & 0.0 & 1.0 & 0.0 \\
\hline Average labor cost & 0.00 & 0.00 & 50.00 & 0.00 \\
\hline Total cost (for system) & 0.00 & 0.00 & 50.00 & 0.00 \\
\hline Total cost (for system) per bus & 0.00 & 0.00 & 4.17 & 0.00 \\
\hline Total cost (for system) per mile & 0.00 & 0.00 & 0.00 & 0.00 \\
\hline
\end{tabular}




\section{Notes}

1. To compare the hydrogen fuel dispensed and fuel economy to diesel, the hydrogen dispensed was also converted into diesel energy equivalent gallons. Actual energy content will vary by locations, but the general energy conversions are as follows:

Lower heating value (LHV) for hydrogen $=51,532 \mathrm{Btu} / \mathrm{lb}$

LHV for diesel $=128,400 \mathrm{Btu} / \mathrm{lb}$

$1 \mathrm{~kg}=2.205 \mathrm{lb}$

$$
51,532 \mathrm{Btu} / \mathrm{lb} * 2.205 \mathrm{lb} / \mathrm{kg}=113,628 \mathrm{Btu} / \mathrm{kg}
$$

Diesel $/$ hydrogen $=128,400 \mathrm{Btu} / \mathrm{gal} / 113,628 \mathrm{Btu} / \mathrm{kg}=1.13 \mathrm{~kg} / \mathrm{diesel}$ gal

2. The propulsion-related systems were chosen to include only those systems of the vehicles that could be affected directly by the selection of a fuel/advanced technology.

3. ATA VMRS coding is based on parts that were replaced. If there was no part replaced in a given repair, then the code was chosen by the system being worked on.

4. In general, inspections (with no part replacements) were included only in the overall totals (not by system). Category 101 was created to track labor costs for PM inspections.

5. ATA VMRS 02-Cab and Sheet Metal represents seats, doors, etc.; ATA VMRS 50Accessories represents things like fire extinguishers, test kits, etc.; ATA VMRS 71-Body represents mostly windows and windshields.

6. Average labor cost is assumed to be $\$ 50$ per hour.

7. Warranty costs are not included. 


\section{Appendix C: ZEBA Fleet Summary Statistics-SI Units}

\section{ZEBA Fleet Operations and Economics}

\begin{tabular}{|c|c|c|c|c|}
\hline & $\begin{array}{l}\text { ZEBA } \\
9 / 11-4 / 12 \\
\text { (Early } \\
\text { Service) }\end{array}$ & $\begin{array}{c}\text { ZEBA } \\
\text { 5/12-2/13 } \\
\text { (Station } \\
\text { Downtime } \\
\text { Period ) }\end{array}$ & $\begin{array}{c}\text { ZEBA } \\
\text { 3/13-12/14 } \\
\text { Data Period }\end{array}$ & $\begin{array}{c}\text { ZEBA } \\
\text { 11/13-12/14 } \\
\text { (Report } \\
\text { Evaluation } \\
\text { Period ) }\end{array}$ \\
\hline Number of vehicles & 12 & 12 & 12 & 12 \\
\hline Period used for fuel and oil op analysis & $9 / 11-4 / 12$ & $5 / 12-2 / 13$ & $3 / 13-12 / 14$ & $11 / 13-12 / 14$ \\
\hline Total number of months in period & 8 & 10 & 22 & 14 \\
\hline Fuel and oil analysis base fleet kilometers & 193,687 & 26,201 & $1,017,792$ & 618,068 \\
\hline Period used for maintenance op analysis & $9 / 11-4 / 12$ & $5 / 12-2 / 13$ & $3 / 13-12 / 14$ & $11 / 13-12 / 14$ \\
\hline Total number of months in period & 8 & 10 & 22 & 14 \\
\hline Maintenance analysis base fleet kilometers & 236,775 & 31,053 & $1,089,210$ & 672,296 \\
\hline Average monthly kilometers per vehicle & 2,572 & - & 4,126 & 4,002 \\
\hline Availability & 1 & - & 1 & 1 \\
\hline Fleet fuel usage $\left(\mathrm{H}_{2}\right.$ in $\mathrm{kg} /$ diesel in liters) & 18,016 & 2,125 & 98,633 & 59,986 \\
\hline Total roadcalls & 73 & - & 113 & 67 \\
\hline KMBRC - all systems & 3,243 & - & 9,639 & 10,034 \\
\hline Propulsion roadcalls & 49 & - & 68 & 40 \\
\hline Propulsion KMBRC & 4,832 & - & 16,018 & 16,807 \\
\hline Fleet kg hydrogen/100 km (1.13 kg H$)$ & 9.30 & 8.11 & 9.69 & 9.71 \\
\hline Rep. fleet fuel consumption (L/100 km) & 31.16 & 27.17 & 32.46 & 32.51 \\
\hline Hydrogen cost per kg & 9.34 & 8.47 & 9.09 & 9.10 \\
\hline Fuel cost per kilometer & 0.87 & 0.69 & 0.88 & 0.88 \\
\hline Total scheduled repair cost per kilometer & 0.01 & 0.05 & 0.10 & 0.11 \\
\hline Total unscheduled repair cost per kilometer & 0.25 & 1.81 & 0.28 & 0.26 \\
\hline Total maintenance cost per kilometer & 0.26 & 1.86 & 0.38 & 0.37 \\
\hline Total operating cost per kilometer & 1.13 & 2.55 & 1.26 & 1.25 \\
\hline Extended Warranty cost (beginning in April 2014) & & & $\$ 287,790$ & $\$ 287,790$ \\
\hline Extra labor costs per kilometer (research, shuttling) & 0.17 & 4.40 & 0.05 & 0.03 \\
\hline $\begin{array}{l}\text { Total operating cost per kilometer (incl. warranty } \\
\text { and extra costs) }\end{array}$ & 1.30 & 6.99 & 1.57 & 1.71 \\
\hline
\end{tabular}

\section{Maintenance Costs}

\begin{tabular}{|c|c|c|c|c|}
\hline & $\begin{array}{c}\text { ZEBA } \\
9 / 11-4 / 12 \\
\text { (Early } \\
\text { Service) }\end{array}$ & $\begin{array}{c}\text { ZEBA } \\
\text { 5/12-2/13 } \\
\text { (Station } \\
\text { Downtime } \\
\text { Period ) }\end{array}$ & $\begin{array}{c}\text { ZEBA } \\
\text { 3/13-12/14 } \\
\text { Data Period }\end{array}$ & $\begin{array}{c}\text { ZEBA } \\
\text { 11/13-12/14 } \\
\text { (Report } \\
\text { Evaluation } \\
\text { Period) }\end{array}$ \\
\hline Fleet mileage & 236,775 & 31,053 & $1,089,210$ & 672,296 \\
\hline Total parts cost & $31,727.9$ & $9,854.4$ & $139,781.4$ & $95,264.1$ \\
\hline Total labor hours & $3,219.70$ & 960.10 & $5,532.00$ & $3,013.62$ \\
\hline Average labor cost (@ \$50.00 per hour) & $160,985.00$ & $48,005.00$ & $276,600.00$ & $150,681.00$ \\
\hline Total maintenance cost & $192,712.88$ & $57,859.44$ & $416,381.43$ & $245,945.05$ \\
\hline Total maintenance cost per bus & $16,059.41$ & $4,821.62$ & $34,698.45$ & $20,495.42$ \\
\hline Total maintenance cost per kilometer & 0.81 & 1.86 & 0.38 & 0.37 \\
\hline
\end{tabular}




\section{Appendix D: ZEBA Monthly Maintenance Analysis Graphs}

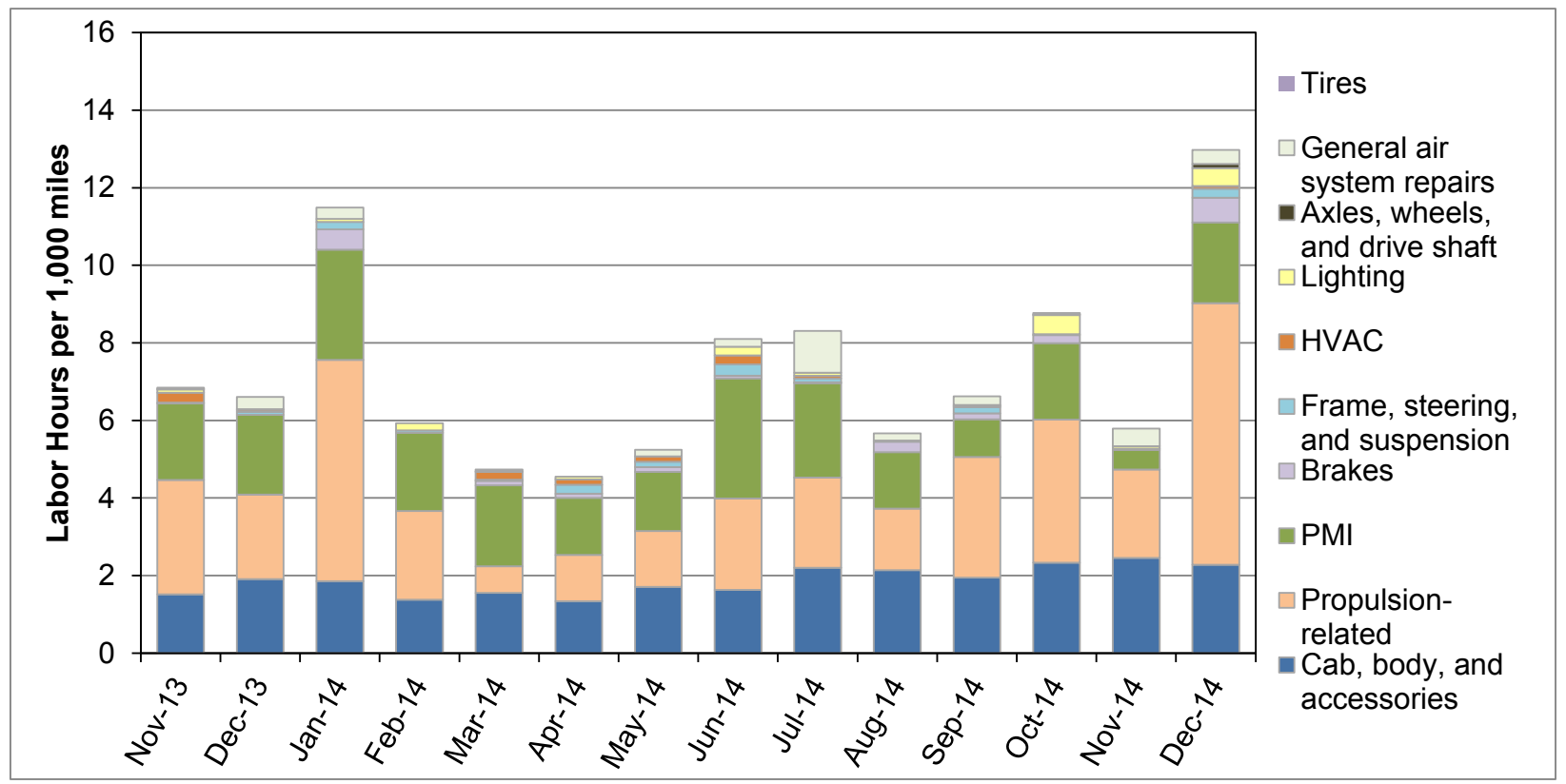

Figure D-1. Monthly labor hours by category for the ZEBA buses

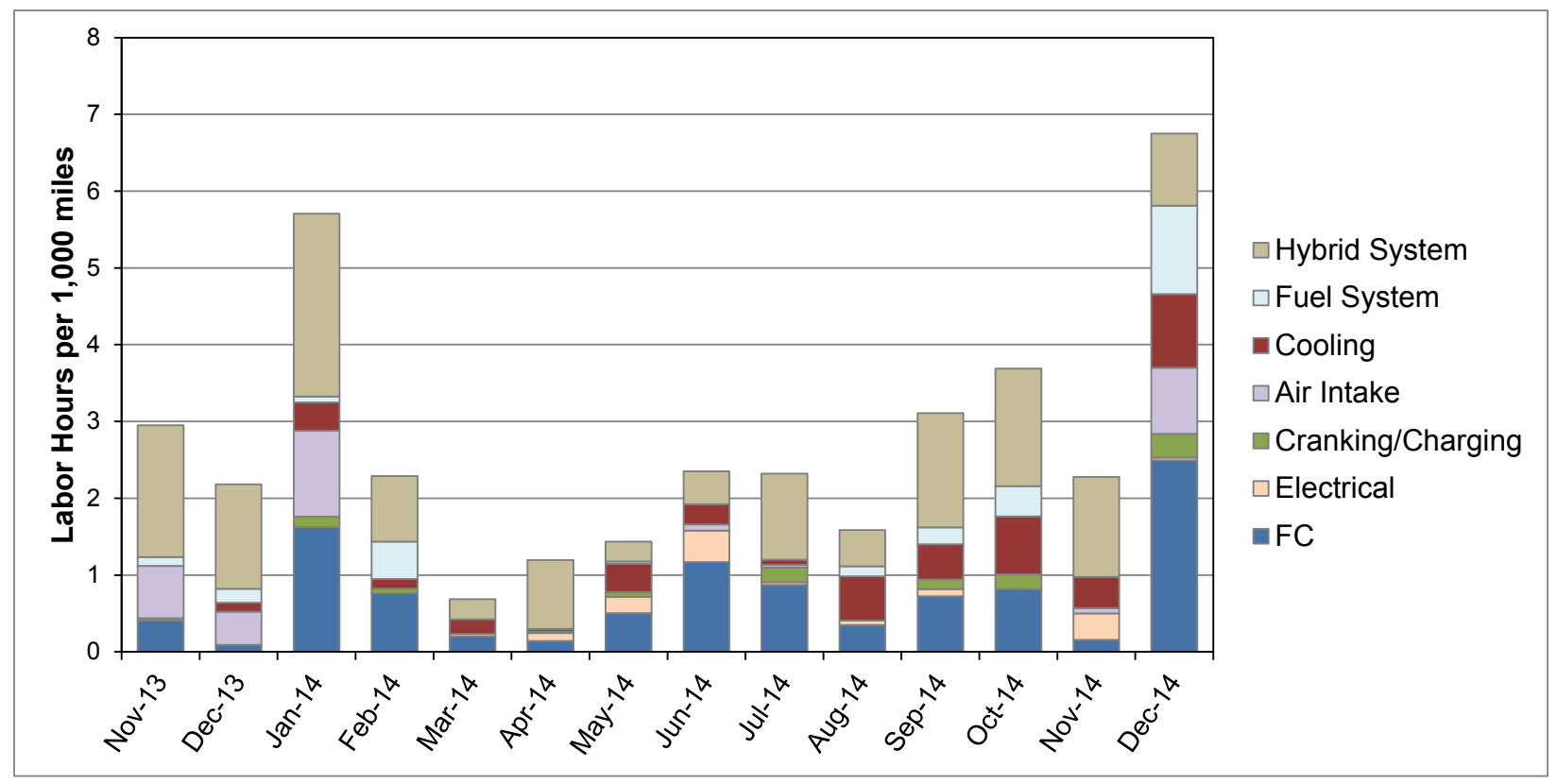

Figure D-2. Monthly propulsion system labor hours by sub-category for the ZEBA buses 


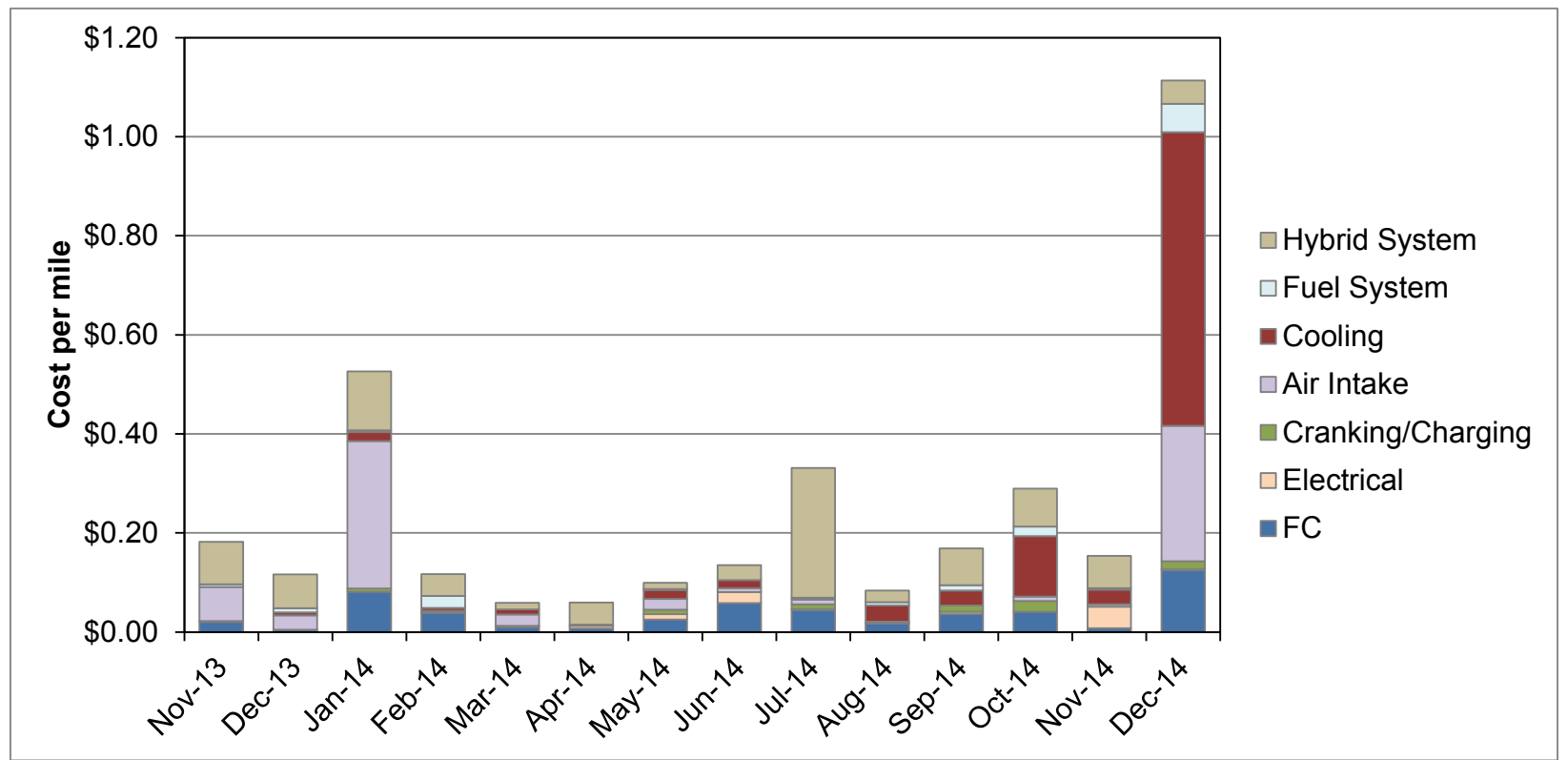

Figure D-3. Monthly propulsion system cost per mile by sub-category for the ZEBA buses 


\section{Appendix E: Diesel Fleet Summary Statistics}

\section{Van Hool and Gillig Diesel Fleet Operations and Economics}

\begin{tabular}{|l|r|r|r|r|r|}
\hline & $\begin{array}{c}\text { Van Hool } \\
\text { Diesel } \\
\text { 9/11-4/12 } \\
\text { Early } \\
\text { Service }\end{array}$ & $\begin{array}{c}\text { Van Hool } \\
\text { Diesel } \\
5 / 12-12 / 14 \\
\text { Data } \\
\text { Period }\end{array}$ & $\begin{array}{c}\text { Van Hool } \\
\text { Diesel } \\
11 / 13-12 / 14 \\
\text { Report } \\
\text { Evaluation } \\
\text { Period }\end{array}$ & $\begin{array}{c}\text { Gillig } \\
\text { Diesel } \\
7 / 13-12 / 14 \\
\text { Data } \\
\text { Period }\end{array}$ & $\begin{array}{c}\text { Gillig Diesel } \\
11 / 13-12 / 14 \\
\text { Report } \\
\text { Evaluation } \\
\text { Period }\end{array}$ \\
\hline Number of vehicles & 3 & 4 & 4 & 10 & 10 \\
\hline Period used for fuel and oil op analysis & $9 / 11-4 / 12$ & $5 / 12-12 / 14$ & $11 / 13-12 / 14$ & $7 / 13-12 / 14$ & $11 / 13-12 / 14$ \\
\hline Total number of months in period & 8 & 32 & 14 & 18 & 14 \\
\hline Fuel and oil analysis base fleet mileage & 82,175 & 325,092 & 213,374 & 807,210 & 651,233 \\
\hline Period used for maintenance op analysis & $9 / 11-4 / 12$ & $5 / 12-12 / 14$ & $11 / 13-12 / 14$ & $7 / 13-12 / 14$ & $11 / 13-10 / 13$ \\
\hline Total number of months in period & 8 & 32 & 14 & 18 & 14 \\
\hline Maintenance analysis base fleet mileage & 83,676 & 425,724 & 226,166 & 911,819 & 685,681 \\
\hline Average monthly mileage per vehicle & 3,635 & 4,225 & 4,349 & 4,847 & 4,898 \\
\hline Availability & $79 \%$ & $80 \%$ & $82 \%$ & $87 \%$ & $88 \%$ \\
\hline Fleet fuel usage (gallons) & $20,532.1$ & $83,390.3$ & $54,036.9$ & $188,057.9$ & $149,411.3$ \\
\hline Total roadcalls & 24 & 101 & 53 & 125 & 82 \\
\hline MBRC - all systems & 3,638 & 3,430 & 4,267 & 7,295 & 8,362 \\
\hline Propulsion roadcalls & 14 & 41 & 23 & 42 & 27 \\
\hline Propulsion MBRC & 5,977 & 8,451 & 9,833 & 21,710 & 25,396 \\
\hline Representative fleet MPG (energy equiv) & 4.00 & 3.90 & 3.95 & 4.29 & 4.36 \\
\hline Diesel cost per gallon & 3.18 & 2.96 & 2.87 & 2.92 & 2.87 \\
\hline Fuel cost per mile & $\mathbf{0 . 7 9}$ & $\mathbf{0 . 7 6}$ & $\mathbf{0 . 7 3}$ & $\mathbf{0 . 6 8}$ & $\mathbf{0 . 6 6}$ \\
\hline Total scheduled repair cost per mile & 0.13 & 0.14 & 0.15 & 0.11 & 0.12 \\
\hline Total unscheduled repair cost per mile & 0.65 & 0.60 & 0.53 & 0.12 & 0.13 \\
\hline Total maintenance cost per mile & $\mathbf{0 . 7 9}$ & $\mathbf{0 . 7 5}$ & $\mathbf{0 . 6 8}$ & $\mathbf{0 . 2 3}$ & $\mathbf{0 . 2 5}$ \\
\hline Total operating cost per mile & $\mathbf{1 . 5 8}$ & $\mathbf{1 . 5 1}$ & $\mathbf{1 . 4 1}$ & $\mathbf{0 . 9 1}$ & $\mathbf{0 . 9 0}$ \\
\hline
\end{tabular}

\section{Maintenance Costs}

\begin{tabular}{|l|r|r|r|r|r|}
\hline & $\begin{array}{r}\text { Van Hool } \\
\text { Diesel } \\
9 / 11-4 / 12 \\
\text { Early } \\
\text { Service }\end{array}$ & $\begin{array}{c}\text { Van Hool } \\
\text { Diesel } \\
5 / 12-12 / 14 \\
\text { Data } \\
\text { Period }\end{array}$ & $\begin{array}{c}\text { Van Hool } \\
\text { Diesel } \\
11 / 13-12 / 14 \\
\text { Report } \\
\text { Evaluation } \\
\text { Period }\end{array}$ & $\begin{array}{c}\text { Gillig } \\
\text { Diesel } \\
7 / 13-12 / 14 \\
\text { Data } \\
\text { Period }\end{array}$ & $\begin{array}{c}\text { Gillig } \\
\text { Diesel } \\
11 / 13-12 / 14 \\
\text { Report } \\
\text { Evaluation } \\
\text { Period }\end{array}$ \\
\hline Fleet mileage & 83,676 & 425,724 & 226,166 & 911,819 & 685,681 \\
\hline Total parts cost & $23,520.4$ & $124,847.3$ & $57,555.6$ & $42,822.5$ & $35,835.5$ \\
\hline Total labor hours & 837.8 & $3,873.5$ & $1,921.7$ & $3,358.3$ & $2,669.7$ \\
\hline Average labor cost (@ \$50.00 per hour) & $41,890.50$ & $193,673.50$ & $96,083.00$ & $167,914.50$ & $133,487.00$ \\
\hline Total maintenance cost & $65,410.94$ & $318,520.75$ & $153,638.63$ & $210,736.96$ & $169,322.52$ \\
\hline Total maintenance cost per bus & $21,803.65$ & $79,630.19$ & $38,409.66$ & $52,684.24$ & $42,330.63$ \\
\hline Total maintenance cost per mile & $\mathbf{0 . 7 8}$ & $\mathbf{0 . 7 5}$ & $\mathbf{0 . 6 8}$ & $\mathbf{0 . 2 3}$ & $\mathbf{0 . 2 5}$ \\
\hline
\end{tabular}


Breakdown of Maintenance Costs by Vehicle System

\begin{tabular}{|c|c|c|c|c|c|}
\hline & $\begin{array}{c}\text { Van Hool } \\
\text { Diesel } \\
9 / 11-4 / 12 \\
\text { Early } \\
\text { Service }\end{array}$ & $\begin{array}{c}\text { Van Hool } \\
\text { Diesel } \\
\text { 5/12-12/14 } \\
\text { Data } \\
\text { Period }\end{array}$ & $\begin{array}{c}\text { Van Hool } \\
\text { Diesel } \\
\text { 11/13-12/14 } \\
\text { Report } \\
\text { Evaluation } \\
\text { Period }\end{array}$ & $\begin{array}{c}\text { Gillig } \\
\text { Diesel } \\
\text { 7/13-12/14 } \\
\text { Data } \\
\text { Period }\end{array}$ & $\begin{array}{c}\text { Gillig } \\
\text { Diesel } \\
11 / 13- \\
12 / 14 \\
\text { Report } \\
\text { Evaluation } \\
\text { Period }\end{array}$ \\
\hline Fleet mileage & 83,676 & 425,724 & 226,166 & 911,819 & 685,681 \\
\hline \multicolumn{6}{|c|}{ Total Engine/Fuel-Related Systems (ATA VMRS 27, 30, 31, 32, 33, 41, 42, 43, 44, 45, 46, 65) } \\
\hline Parts cost & $8,142.90$ & $47,153.10$ & $17,930.50$ & $22,574.86$ & $18,102.44$ \\
\hline Labor hours & 201.9 & $1,112.3$ & 474.4 & 597.0 & 491.3 \\
\hline Average labor cost & $10,092.50$ & $55,614.50$ & $23,719.50$ & $29,850.00$ & $24,562.50$ \\
\hline Total cost (for system) & $18,235.40$ & $102,767.60$ & $41,650.00$ & $52,424.86$ & $42,664.94$ \\
\hline Total cost (for system) per bus & $6,078.47$ & $25,691.90$ & $10,412.50$ & $13,106.21$ & $10,666.24$ \\
\hline Total cost (for system) per mile & 0.22 & 0.24 & 0.18 & 0.06 & 0.06 \\
\hline \multicolumn{6}{|c|}{ Exhaust System Repairs (ATA VMRS 43) } \\
\hline Parts cost & 217.32 & $16,597.70$ & $5,086.94$ & 42.71 & 42.71 \\
\hline Labor hours & 3.4 & 182.4 & 74.8 & 24.2 & 24.2 \\
\hline Average labor cost & 170.00 & $9,117.50$ & $3,737.50$ & $1,210.50$ & $1,210.50$ \\
\hline Total cost (for system) & 387.32 & $25,715.20$ & $8,824.44$ & $1,253.21$ & $1,253.21$ \\
\hline Total cost (for system) per bus & 129.11 & $6,428.80$ & $2,206.11$ & 313.30 & 313.30 \\
\hline Total cost (for system) per mile & 0.00 & 0.06 & 0.04 & 0.00 & 0.00 \\
\hline \multicolumn{6}{|c|}{ Fuel System Repairs (ATA VMRS 44) } \\
\hline Parts cost & 692.04 & $3,742.44$ & $1,303.16$ & $4,341.37$ & $3,313.07$ \\
\hline Labor hours & 9.6 & 108.3 & 32.2 & 51.5 & 31.6 \\
\hline Average labor cost & 480.00 & $5,414.50$ & $1,609.50$ & $2,573.00$ & $1,578.00$ \\
\hline Total cost (for system) & $1,172.04$ & $9,156.94$ & $2,912.66$ & $6,914.37$ & $4,891.07$ \\
\hline Total cost (for system) per bus & 390.68 & $2,289.23$ & 728.17 & $1,728.59$ & $1,222.77$ \\
\hline Total cost (for system) per mile & 0.01 & 0.02 & 0.01 & 0.01 & 0.01 \\
\hline \multicolumn{6}{|c|}{ Power Plant (Engine) Repairs (ATA VMRS 45) } \\
\hline Parts cost & $3,767.42$ & $5,205.46$ & $1,530.22$ & $4,973.59$ & $3,278.76$ \\
\hline Labor hours & 100.0 & 307.6 & 115.6 & 167.7 & 132.5 \\
\hline Average labor cost & $5,000.00$ & $15,379.00$ & $5,779.00$ & $8,386.00$ & $6,626.00$ \\
\hline Total cost (for system) & $8,767.42$ & $20,584.46$ & $7,309.22$ & $13,359.59$ & $9,904.76$ \\
\hline Total cost (for system) per bus & $2,922.47$ & $5,146.11$ & $1,827.31$ & $3,339.90$ & $2,476.19$ \\
\hline Total cost (for system) per mile & 0.10 & 0.05 & 0.03 & 0.01 & 0.01 \\
\hline \multicolumn{6}{|l|}{$\begin{array}{l}\text { Electric Propulsion Repairs (ATA } \\
\text { VMRS 46) }\end{array}$} \\
\hline Parts cost & 0.00 & 0.00 & 0.00 & 0.00 & 0.00 \\
\hline Labor hours & 0.0 & 0.0 & 0.0 & 0.0 & 0.0 \\
\hline Average labor cost & 0.00 & 0.00 & 0.00 & 0.00 & 0.00 \\
\hline Total cost (for system) & 0.00 & 0.00 & 0.00 & 0.00 & 0.00 \\
\hline Total cost (for system) per bus & 0.00 & 0.00 & 0.00 & 0.00 & 0.00 \\
\hline Total cost (for system) per mile & 0.00 & 0.00 & 0.00 & 0.00 & 0.00 \\
\hline
\end{tabular}


Breakdown of Maintenance Costs by Vehicle System (continued)

\begin{tabular}{|c|c|c|c|c|c|}
\hline & $\begin{array}{c}\text { Van Hool } \\
\text { Diesel } \\
9 / 11-4 / 12 \\
\text { Early } \\
\text { Service }\end{array}$ & $\begin{array}{c}\text { Van Hool } \\
\text { Diesel } \\
\text { 5/12-12/14 } \\
\text { Data } \\
\text { Period }\end{array}$ & $\begin{array}{c}\text { Van Hool } \\
\text { Diesel } \\
\text { 11/13-12/14 } \\
\text { Report } \\
\text { Evaluation } \\
\text { Period }\end{array}$ & $\begin{array}{c}\text { Gillig } \\
\text { Diesel } \\
\text { 7/13-12/14 } \\
\text { Data } \\
\text { Period }\end{array}$ & $\begin{array}{c}\text { Gillig } \\
\text { Diesel } \\
11 / 13- \\
12 / 14 \\
\text { Report } \\
\text { Evaluation } \\
\text { Period } \\
\end{array}$ \\
\hline \multicolumn{6}{|c|}{ Electrical System Repairs (ATA VMRS 30-Electrical General, 31-Charging, 32-Cranking, 33-Ignition) } \\
\hline Parts cost & 51.63 & $3,410.72$ & 909.86 & $2,021.99$ & $1,880.11$ \\
\hline Labor hours & 20.7 & 76.0 & 37.5 & 134.9 & 110.1 \\
\hline Average labor cost & $1,032.50$ & $3,801.00$ & $1,876.00$ & $6,745.00$ & $5,505.00$ \\
\hline Total cost (for system) & $1,084.13$ & $7,211.72$ & $2,785.86$ & $8,766.99$ & $7,385.11$ \\
\hline Total cost (for system) per bus & 361.38 & $1,802.93$ & 696.46 & $2,191.75$ & $1,846.28$ \\
\hline Total cost (for system) per mile & 0.01 & 0.02 & 0.01 & 0.01 & 0.01 \\
\hline \multicolumn{6}{|c|}{ Air Intake System Repairs (ATA VMRS 41) } \\
\hline Parts cost & 801.89 & $3,988.27$ & $2,921.71$ & $4,828.69$ & $4,012.04$ \\
\hline Labor hours & 16.9 & 112.9 & 51.8 & 59.3 & 55.5 \\
\hline Average labor cost & 845.00 & $5,645.50$ & $2,590.50$ & $2,964.00$ & $2,774.00$ \\
\hline Total cost (for system) & $1,646.89$ & $9,633.77$ & $5,512.21$ & $7,792.69$ & $6,786.04$ \\
\hline Total cost (for system) per bus & 548.96 & $2,408.44$ & $1,378.05$ & $1,948.17$ & $1,696.51$ \\
\hline Total cost (for system) per mile & 0.02 & 0.02 & 0.02 & 0.01 & 0.01 \\
\hline \multicolumn{6}{|c|}{ Cooling System Repairs (ATA VMRS 42) } \\
\hline Parts cost & $1,484.11$ & $11,773.15$ & $5,524.64$ & $4,807.48$ & $4,445.32$ \\
\hline Labor hours & 48.0 & 241.3 & 142.1 & 58.8 & 52.2 \\
\hline Average labor cost & $2,400.00$ & $12,062.50$ & $7,102.50$ & $2,937.50$ & $2,610.00$ \\
\hline Total cost (for system) & $3,884.11$ & $23,835.65$ & $12,627.14$ & $7,744.98$ & $7,055.32$ \\
\hline Total cost (for system) per bus & $1,294.70$ & $5,958.91$ & $3,156.79$ & $1,936.24$ & $1,763.83$ \\
\hline Total cost (for system) per mile & 0.05 & 0.06 & 0.06 & 0.01 & 0.01 \\
\hline \multicolumn{6}{|c|}{ Hydraulic System Repairs (ATA VMRS 65) } \\
\hline Parts cost & 0.00 & $1,807.22$ & 243.29 & 786.72 & 619.40 \\
\hline Labor hours & 0.0 & 45.3 & 4.1 & 9.3 & 9.1 \\
\hline Average labor cost & 0.00 & $2,267.00$ & 207.00 & 462.50 & 452.50 \\
\hline Total cost (for system) & 0.00 & $4,074.22$ & 450.29 & $1,249.22$ & $1,071.90$ \\
\hline Total cost (for system) per bus & 0.00 & $1,018.56$ & 112.57 & 312.31 & 267.98 \\
\hline Total cost (for system) per mile & 0.00 & 0.01 & 0.00 & 0.00 & 0.00 \\
\hline \multicolumn{6}{|c|}{ General Air System Repairs (ATA VMRS 10) } \\
\hline Parts cost & 723.46 & $3,921.57$ & $1,927.47$ & 50.77 & 50.77 \\
\hline Labor hours & 35.7 & 166.7 & 71.1 & 20.8 & 19.8 \\
\hline Average labor cost & $1,785.00$ & $8,336.50$ & $3,556.50$ & $1,041.00$ & 991.00 \\
\hline Total cost (for system) & $2,508.46$ & $12,258.07$ & $5,483.97$ & $1,091.77$ & $1,041.77$ \\
\hline Total cost (for system) per bus & 836.15 & $3,064.52$ & $1,370.99$ & 272.94 & 260.44 \\
\hline Total cost (for system) per mile & 0.03 & 0.03 & 0.02 & 0.00 & 0.00 \\
\hline
\end{tabular}


Breakdown of Maintenance Costs by Vehicle System (continued)

\begin{tabular}{|c|c|c|c|c|c|}
\hline & $\begin{array}{c}\text { Van Hool } \\
\text { Diesel } \\
9 / 11-4 / 12 \\
\text { Early } \\
\text { Service }\end{array}$ & $\begin{array}{c}\text { Van Hool } \\
\text { Diesel } \\
\text { 5/12-12/14 } \\
\text { Data } \\
\text { Period }\end{array}$ & $\begin{array}{c}\text { Van Hool } \\
\text { Diesel } \\
\text { 11/13-12/14 } \\
\text { Report } \\
\text { Evaluation } \\
\text { Period }\end{array}$ & $\begin{array}{c}\text { Gillig } \\
\text { Diesel } \\
\text { 7/13-12/14 } \\
\text { Data } \\
\text { Period }\end{array}$ & $\begin{array}{c}\text { Gillig Diesel } \\
\text { 11/13-12/14 } \\
\text { Report } \\
\text { Evaluation } \\
\text { Period }\end{array}$ \\
\hline \multicolumn{6}{|c|}{ Brake System Repairs (ATA VMRS 13) } \\
\hline Parts cost & $7,301.74$ & $26,590.23$ & $13,189.27$ & $2,219.67$ & $2,219.67$ \\
\hline Labor hours & 83.5 & 317.4 & 118.7 & 101.5 & 101.5 \\
\hline Average labor cost & $4,172.50$ & $15,870.50$ & $5,933.00$ & $5,076.00$ & $5,076.00$ \\
\hline Total cost (for system) & $11,474.24$ & $42,460.73$ & $19,122.27$ & $7,295.67$ & $7,295.67$ \\
\hline Total cost (for system) per bus & $3,824.75$ & $10,615.18$ & $4,780.57$ & $1,823.92$ & $1,823.92$ \\
\hline Total cost (for system) per mile & 0.14 & 0.10 & 0.08 & 0.01 & 0.01 \\
\hline \multicolumn{6}{|c|}{ Transmission Repairs (ATA VMRS 27) } \\
\hline Parts cost & $1,128.49$ & 628.13 & 410.67 & 772.31 & 511.04 \\
\hline Labor hours & 3.3 & 38.6 & 16.4 & 91.4 & 76.1 \\
\hline Average labor cost & 165.00 & $1,927.50$ & 817.50 & $4,571.50$ & $3,806.50$ \\
\hline Total cost (for system) & $1,293.49$ & $2,555.63$ & $1,228.17$ & $5,343.81$ & $4,317.54$ \\
\hline Total cost (for system) per bus & 431.16 & 638.91 & 307.04 & $1,335.95$ & $1,079.38$ \\
\hline Total cost (for system) per mile & 0.02 & 0.01 & 0.01 & 0.01 & 0.01 \\
\hline \multicolumn{6}{|c|}{ Inspections Only - no parts replacements (101) } \\
\hline Parts cost & 0.00 & 0.00 & 0.00 & 0.00 & 0.00 \\
\hline Labor hours & 140.1 & 582.7 & 284.5 & $1,009.6$ & 711.8 \\
\hline Average labor cost & $7,005.00$ & $29,136.00$ & $14,226.00$ & $50,477.50$ & $35,587.50$ \\
\hline Total cost (for system) & $7,005.00$ & $29,136.00$ & $14,226.00$ & $50,477.50$ & $35,587.50$ \\
\hline Total cost (for system) per bus & $2,335.00$ & $7,284.00$ & $3,556.50$ & $12,619.38$ & $8,896.88$ \\
\hline Total cost (for system) per mile & 0.08 & 0.07 & 0.06 & 0.06 & 0.05 \\
\hline \multicolumn{6}{|c|}{ Cab, Body, and Accessories Systems Repairs (ATA VMRS 02-Cab and Sheet Metal, 50-Accessories, 71-Body) } \\
\hline Parts cost & $4,695.10$ & $18,962.61$ & $8,845.99$ & $15,593.63$ & $13,224.29$ \\
\hline Labor hours & 344.1 & $1,111.2$ & 603.9 & $1,388.7$ & $1,130.6$ \\
\hline Average labor cost & $17,203.00$ & $55,562.00$ & $30,194.00$ & $69,435.00$ & $56,530.00$ \\
\hline Total cost (for system) & $21,898.10$ & $74,524.61$ & $39,039.99$ & $85,028.63$ & $69,754.29$ \\
\hline Total cost (for system) per bus & $7,299.37$ & $18,631.15$ & $9,760.00$ & $21,257.16$ & $17,438.57$ \\
\hline Total cost (for system) per mile & 0.26 & 0.18 & 0.17 & 0.09 & 0.10 \\
\hline \multicolumn{6}{|c|}{ HVAC System Repairs (ATA VMRS 01) } \\
\hline Parts cost & $1,914.87$ & $15,136.92$ & $7,673.67$ & $1,339.29$ & $1,339.29$ \\
\hline Labor hours & 8.4 & 249.0 & 152.8 & 128.9 & 123.0 \\
\hline Average labor cost & 420.00 & $12,451.00$ & $7,641.00$ & $6,444.50$ & $6,149.50$ \\
\hline Total cost (for system) & $2,334.87$ & $27,587.92$ & $15,314.67$ & $7,783.79$ & $7,488.79$ \\
\hline Total cost (for system) per bus & 778.29 & $6,896.98$ & $3,828.67$ & $1,945.95$ & $1,872.20$ \\
\hline Total cost (for system) per mile & 0.03 & 0.06 & 0.07 & 0.01 & 0.01 \\
\hline
\end{tabular}


Breakdown of Maintenance Costs by Vehicle System (continued)

\begin{tabular}{|c|c|c|c|c|c|}
\hline & $\begin{array}{c}\text { Van Hool } \\
\text { Diesel } \\
9 / 11-4 / 12 \\
\text { Early } \\
\text { Service }\end{array}$ & $\begin{array}{c}\text { Van Hool } \\
\text { Diesel } \\
\text { 5/12-12/14 } \\
\text { Data } \\
\text { Period }\end{array}$ & $\begin{array}{c}\text { Van Hool } \\
\text { Diesel } \\
\text { 11/13-12/14 } \\
\text { Report } \\
\text { Evaluation } \\
\text { Period }\end{array}$ & $\begin{array}{c}\text { Gillig } \\
\text { Diesel } \\
\text { 7/13-12/14 } \\
\text { Data } \\
\text { Period }\end{array}$ & $\begin{array}{c}\text { Gillig } \\
\text { Diesel } \\
11 / 13- \\
12 / 14 \\
\text { Report } \\
\text { Evaluation } \\
\text { Period }\end{array}$ \\
\hline \multicolumn{6}{|c|}{ Lighting System Repairs (ATA VMRS 34) } \\
\hline Parts cost & 71.59 & $1,224.45$ & 613.43 & 592.47 & 587.16 \\
\hline Labor hours & 1.3 & 68.5 & 48.5 & 35.7 & 33.2 \\
\hline Average labor cost & 62.50 & $3,423.00$ & $2,423.00$ & $1,786.50$ & $1,661.50$ \\
\hline Total cost (for system) & 134.09 & $4,647.45$ & $3,036.43$ & $2,378.97$ & $2,248.66$ \\
\hline Total cost (for system) per bus & 44.70 & $1,161.86$ & 759.11 & 594.74 & 562.17 \\
\hline Total cost (for system) per mile & 0.00 & 0.01 & 0.01 & 0.00 & 0.00 \\
\hline \multicolumn{6}{|c|}{ Frame, Steering, and Suspension Repairs (ATA VMRS 14-Frame, 15-Steering, 16-Suspension) } \\
\hline Parts cost & 375.92 & $6,539.18$ & $4,554.35$ & 218.39 & 89.20 \\
\hline Labor hours & 10.5 & 112.1 & 64.0 & 35.5 & 21.5 \\
\hline Average labor cost & 525.00 & $5,603.00$ & $3,198.00$ & $1,773.00$ & $1,073.00$ \\
\hline Total cost (for system) & 900.92 & $12,142.18$ & $7,752.35$ & $1,991.39$ & $1,162.20$ \\
\hline Total cost (for system) per bus & 300.31 & $3,035.54$ & $1,938.09$ & 497.85 & 290.55 \\
\hline Total cost (for system) per mile & 0.01 & 0.03 & 0.03 & 0.00 & 0.00 \\
\hline \multicolumn{6}{|c|}{ Axle, Wheel, and Drive Shaft Repairs (ATA VMRS 11-Front Axle, 18-Wheels, 22-Rear Axle, 24-Drive Shaft) } \\
\hline Parts cost & 294.86 & $5,310.44$ & $2,772.77$ & 233.39 & 222.70 \\
\hline Labor hours & 12.5 & 150.5 & 101.8 & 23.8 & 21.3 \\
\hline Average labor cost & 625.00 & $7,527.00$ & $5,092.00$ & $1,189.50$ & $1,064.50$ \\
\hline Total cost (for system) & 919.86 & $12,837.44$ & $7,864.77$ & $1,422.89$ & $1,287.20$ \\
\hline Total cost (for system) per bus & 306.62 & $3,209.36$ & $1,966.19$ & 355.72 & 321.80 \\
\hline Total cost (for system) per mile & 0.01 & 0.03 & 0.03 & 0.00 & 0.00 \\
\hline \multicolumn{6}{|l|}{ Tire Repairs (ATA VMRS 17) } \\
\hline Parts cost & 0.00 & 0.00 & 0.00 & 0.00 & 0.00 \\
\hline Labor hours & 0.00 & 8.0 & 2.0 & 16.8 & 15.8 \\
\hline Average labor cost & 0.00 & 400.00 & 100.00 & 841.50 & 791.50 \\
\hline Total cost (for system) & 0.00 & 400.00 & 100.00 & 841.50 & 791.50 \\
\hline Total cost (for system) per bus & 0.00 & 100.00 & 25.00 & 210.38 & 197.88 \\
\hline Total cost (for system) per mile & 0.00 & 0.00 & 0.00 & 0.00 & 0.00 \\
\hline
\end{tabular}




\section{Appendix F: Diesel Fleet Summary Statistics—SI Units}

\section{Van Hool and Gillig Diesel Fleet Operations and Economics}

\begin{tabular}{|c|c|c|c|c|c|}
\hline & $\begin{array}{l}\text { Van Hool } \\
\text { Diesel } \\
9 / 11-4 / 12 \\
\text { Early } \\
\text { Service }\end{array}$ & $\begin{array}{c}\text { Van Hool } \\
\text { Diesel } \\
\text { 5/12-12/14 } \\
\text { Data } \\
\text { Period }\end{array}$ & $\begin{array}{c}\text { Van Hool } \\
\text { Diesel } \\
\text { 11/13-12/14 } \\
\text { Report } \\
\text { Evaluation } \\
\text { Period }\end{array}$ & $\begin{array}{c}\text { Gillig } \\
\text { Diesel } \\
\text { 7/13-12/14 } \\
\text { Data } \\
\text { Period }\end{array}$ & $\begin{array}{c}\text { Gillig Diesel } \\
\text { 7/13-12/14 } \\
\text { Report } \\
\text { Evaluation } \\
\text { Period }\end{array}$ \\
\hline Number of vehicles & 3 & 3 & 3 & 3 & 3 \\
\hline Period used for fuel and oil op analysis & $9 / 11-4 / 12$ & $5 / 12-12 / 14$ & $11 / 13-12 / 14$ & $7 / 13-12 / 14$ & $11 / 13-12 / 14$ \\
\hline Total number of months in period & 8 & 32 & 14 & 18 & 14 \\
\hline Fuel and oil analysis base fleet kilometers & 132,244 & 523,171 & 343,383 & $1,299,043$ & $1,048,029$ \\
\hline Period used for maintenance op analysis & $9 / 11-4 / 12$ & $5 / 12-12 / 14$ & $11 / 13-12 / 14$ & $7 / 13-12 / 14$ & $11 / 13-10 / 13$ \\
\hline Total number of months in period & 8 & 32 & 14 & 18 & 14 \\
\hline Maintenance analysis base fleet kilometers & 134,660 & 685,117 & 363,969 & $1,467,390$ & $1,103,466$ \\
\hline Average monthly kilometers per vehicle & 5,611 & 7,137 & 8,666 & 27,174 & 26,273 \\
\hline Availability & 1 & 1 & 1 & 1 & 1 \\
\hline Fleet fuel usage (L) & 77,722 & 315,667 & 204,552 & 711,877 & 565,583 \\
\hline Total roadcalls & 24 & 101 & 53 & 125 & 82 \\
\hline KMBRC - all systems & 5,611 & 6,783 & 6,867 & 11,739 & 13,457 \\
\hline Propulsion roadcalls & 14 & 41 & 23 & 42 & 27 \\
\hline Propulsion KMBRC & 9,619 & 16,710 & 15,825 & 34,938 & 40,869 \\
\hline Rep. fleet fuel consumption (L/100 km) & 58.77 & 60.34 & 59.57 & 54.80 & 53.97 \\
\hline Diesel cost/liter & 0.84 & 0.78 & 0.76 & 0.77 & 0.76 \\
\hline Fuel cost per kilometer & 0.49 & 0.47 & 0.45 & 0.42 & 0.41 \\
\hline Total scheduled repair cost per kilometer & 0.21 & 0.09 & 0.09 & 0.07 & 0.07 \\
\hline Total unscheduled repair cost per kilometer & 1.09 & 0.38 & 0.33 & 0.07 & 0.08 \\
\hline Total maintenance cost per kilometer & 1.30 & 0.46 & 0.42 & 0.14 & 0.15 \\
\hline Total operating cost per kilometer & 1.79 & 0.94 & 0.87 & 0.57 & 0.56 \\
\hline
\end{tabular}

\section{Maintenance Costs}

\begin{tabular}{|l|r|r|r|r|r|}
\hline & $\begin{array}{r}\text { Van Hool } \\
\text { Diesel } \\
9 / 11-4 / 12 \\
\text { Early } \\
\text { Service }\end{array}$ & $\begin{array}{c}\text { Van Hool } \\
\text { Diesel } \\
5 / 12-12 / 14 \\
\text { Data } \\
\text { Period }\end{array}$ & $\begin{array}{r}\text { Van Hool } \\
\text { Diesel } \\
11 / 13-12 / 14 \\
\text { Report } \\
\text { Evaluation } \\
\text { Period }\end{array}$ & $\begin{array}{c}\text { Gillig } \\
\text { Diesel } \\
7 / 13-12 / 14 \\
\text { Data } \\
\text { Period }\end{array}$ & $\begin{array}{r}\text { Gillig Diesel } \\
7 / 13-12 / 14 \\
\text { Report } \\
\text { Evaluation } \\
\text { Period }\end{array}$ \\
\hline Fleet kilometers & 134,660 & 685,117 & 363,969 & $1,467,390$ & $1,103,466$ \\
\hline Total parts cost & $23,520.4$ & $124,847.3$ & $57,555.6$ & $42,822.5$ & $35,835.5$ \\
\hline Total labor hours & 837.8 & $3,873.5$ & $1,921.7$ & $3,358.3$ & $2,669.7$ \\
\hline Average labor cost @ \$50.00 per hour) & $41,890.50$ & $193,673.50$ & $96,083.00$ & $167,914.50$ & $133,487.00$ \\
\hline Total maintenance cost & $65,410.94$ & $318,520.75$ & $153,638.63$ & $210,736.96$ & $169,322.52$ \\
\hline Total maintenance cost per bus & $21,803.65$ & $106,173.58$ & $51,212.88$ & $70,245.65$ & $56,440.84$ \\
\hline Total maintenance cost per kilometer & $\mathbf{0 . 4 9}$ & $\mathbf{0 . 4 6}$ & $\mathbf{0 . 4 2}$ & $\mathbf{0 . 1 4}$ & $\mathbf{0 . 1 5}$ \\
\hline
\end{tabular}




\section{Appendix G: Diesel Monthly Labor Hour Graphs}

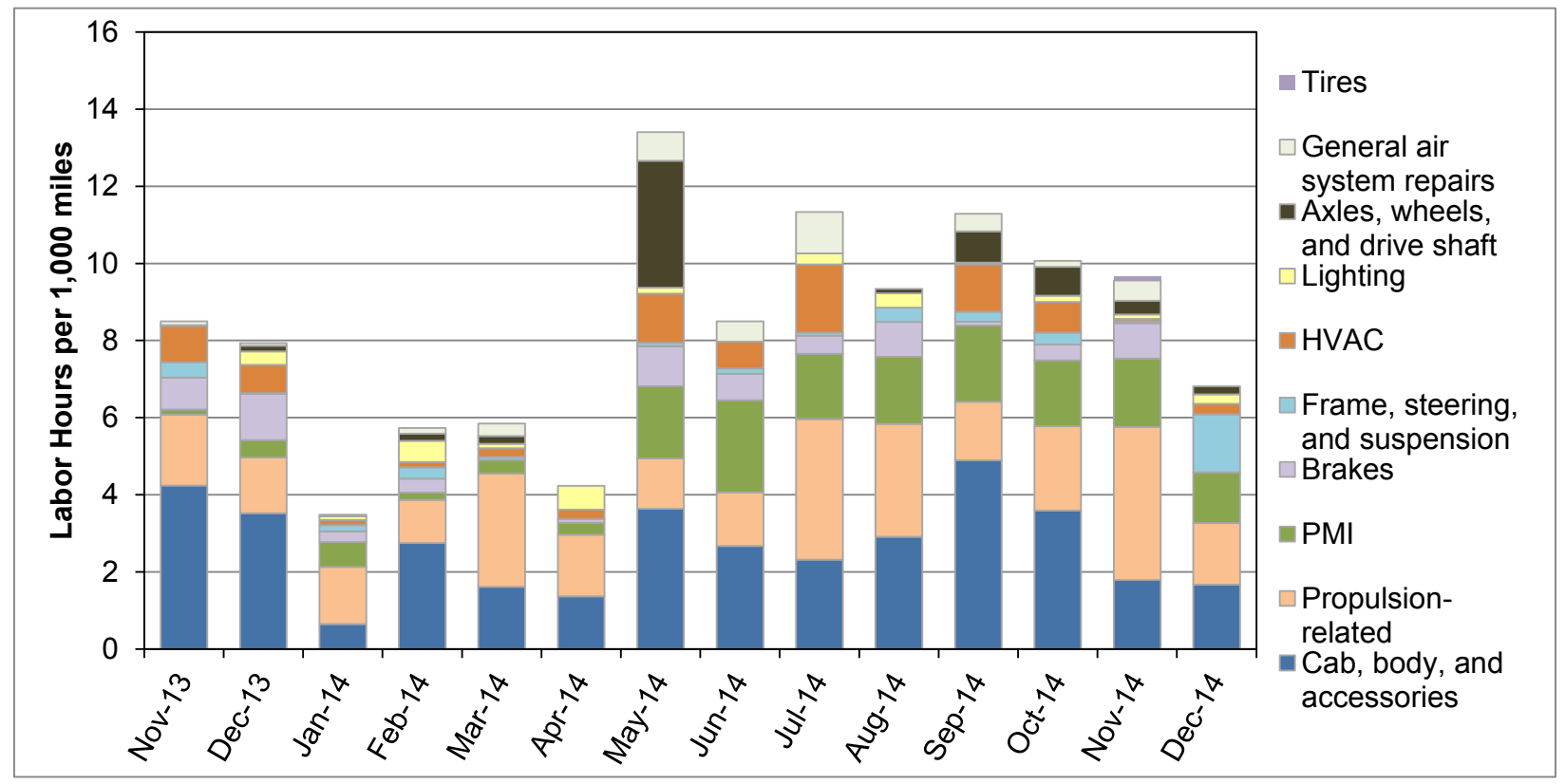

Figure G-1. Monthly labor hours by category for the Van Hool diesel buses

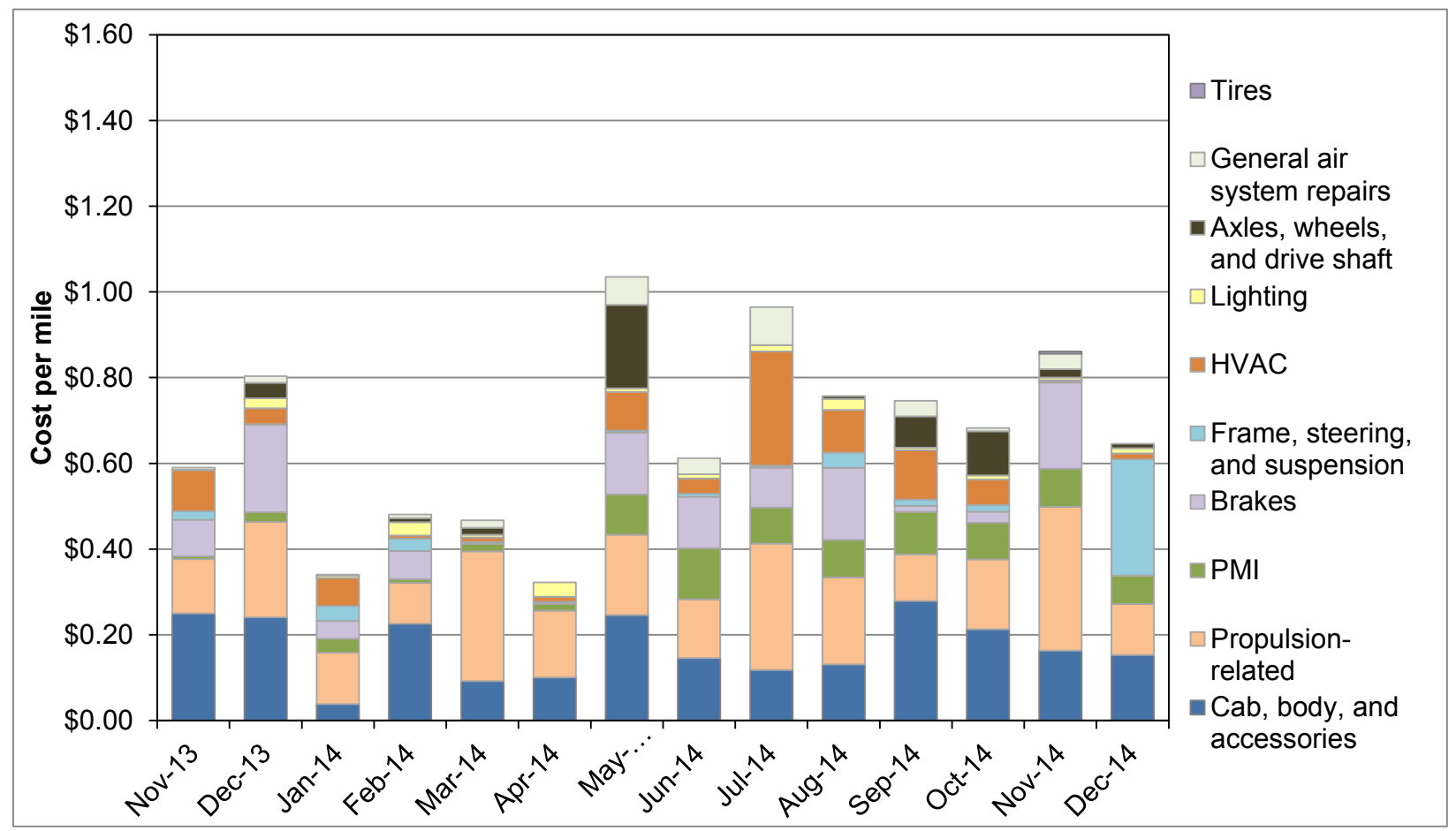

Figure G-2. Monthly cost per mile by category for the Van Hool diesel buses 


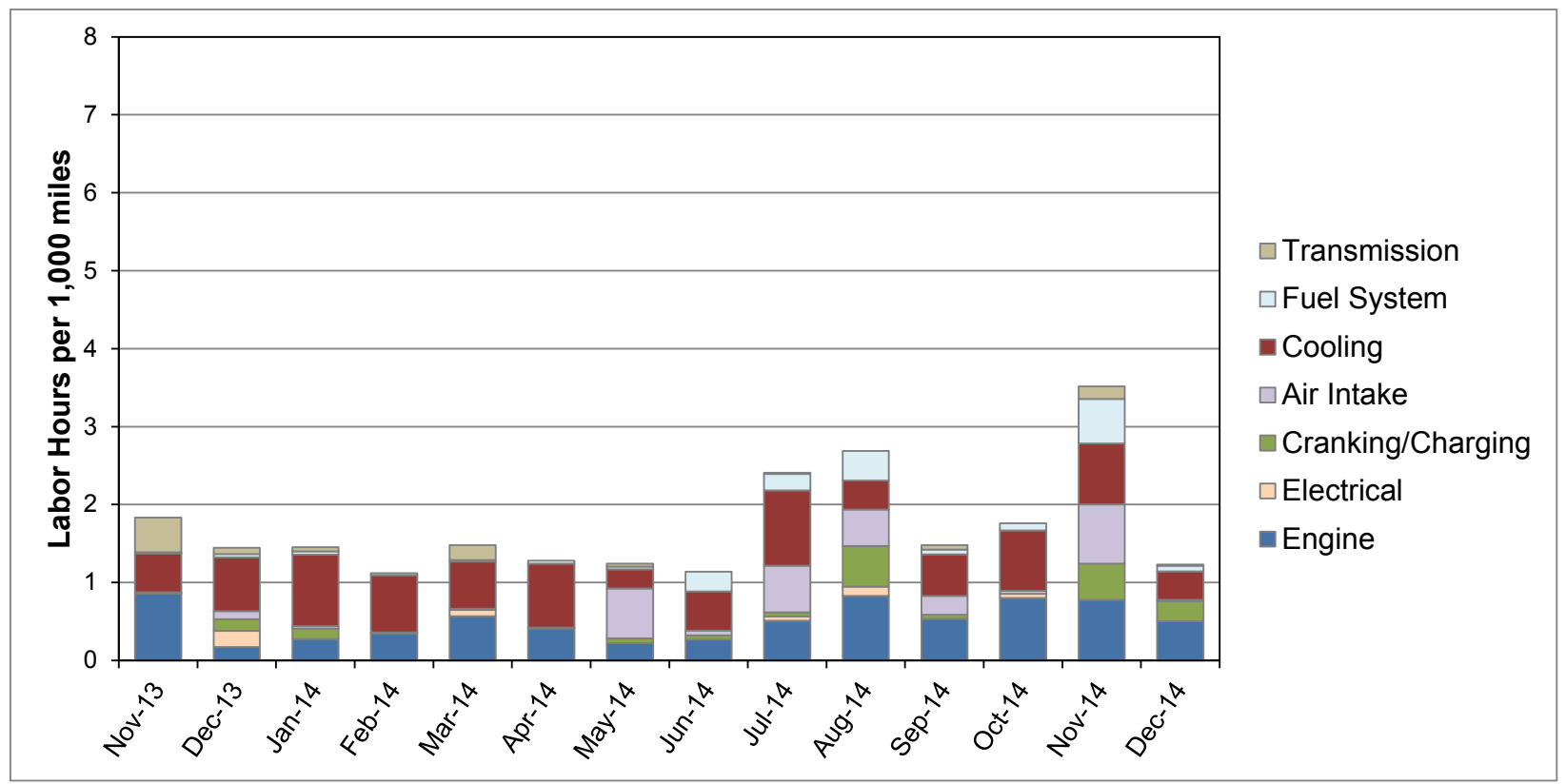

Figure G-3. Monthly propulsion system labor hours by sub-category for the Van Hool diesel buses

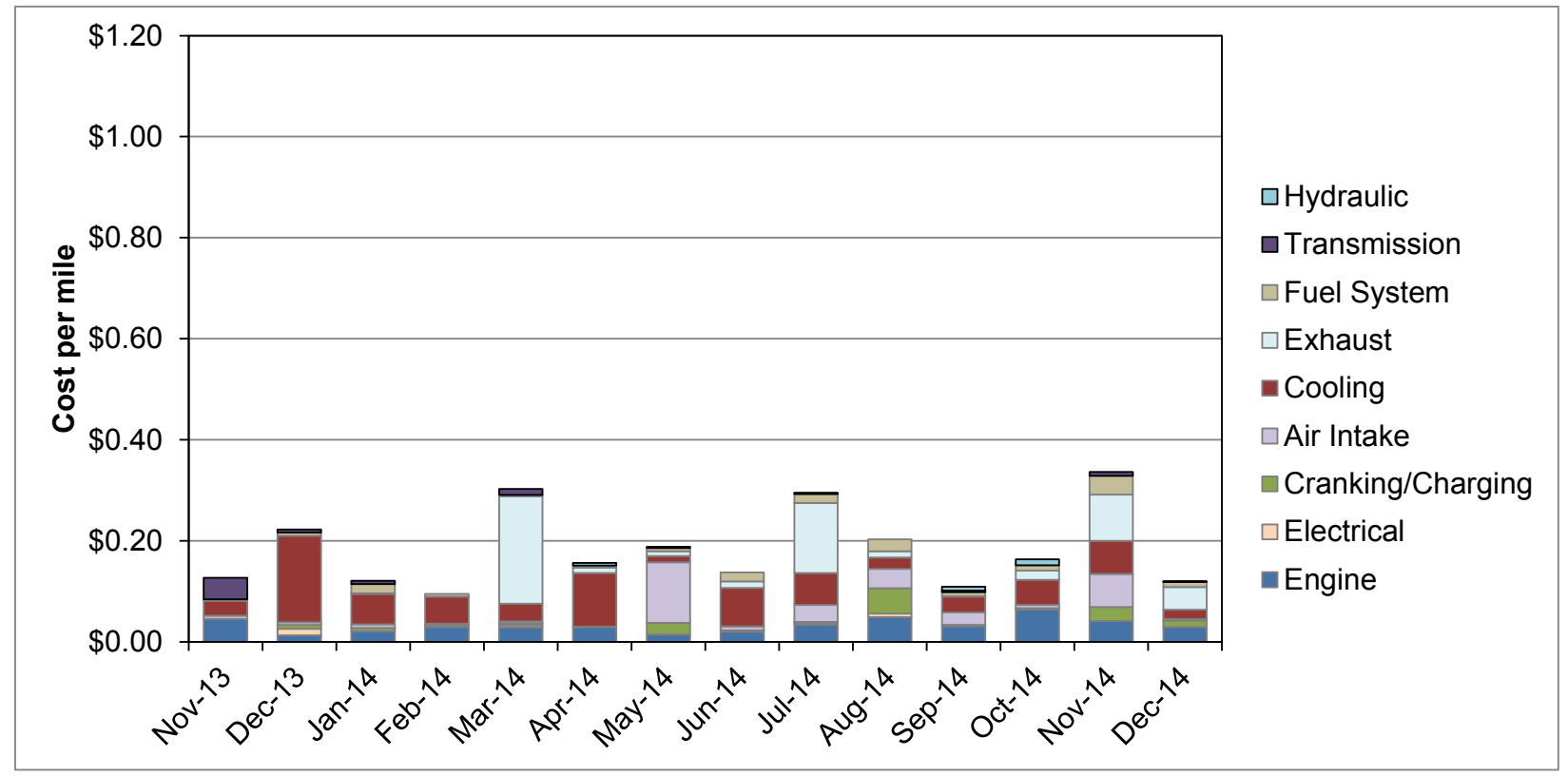

Figure G-4. Monthly propulsion system cost per mile by sub-category for the Van Hool diesel buses 


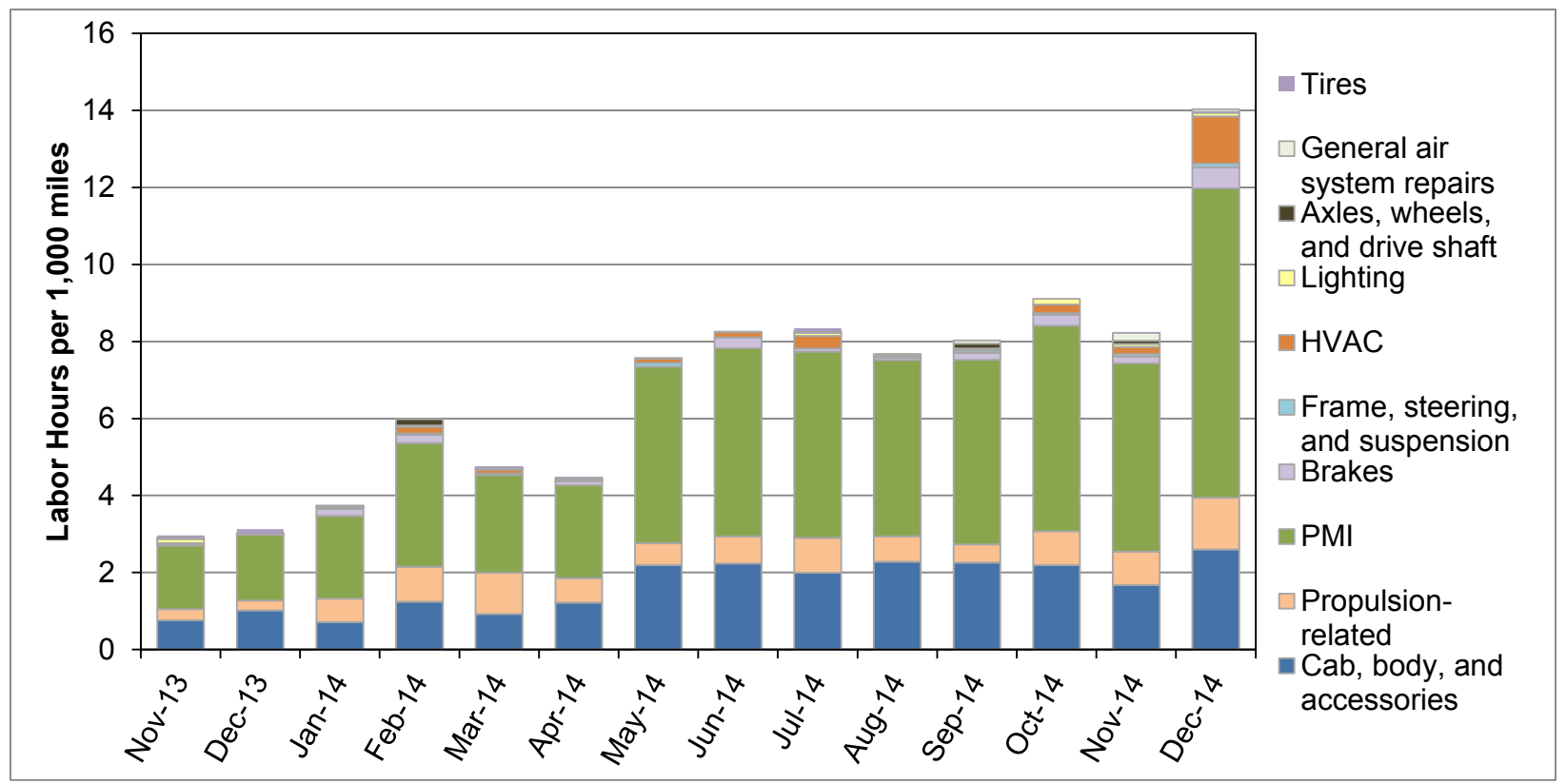

Figure G-5. Monthly labor hours by category for the Gillig diesel buses

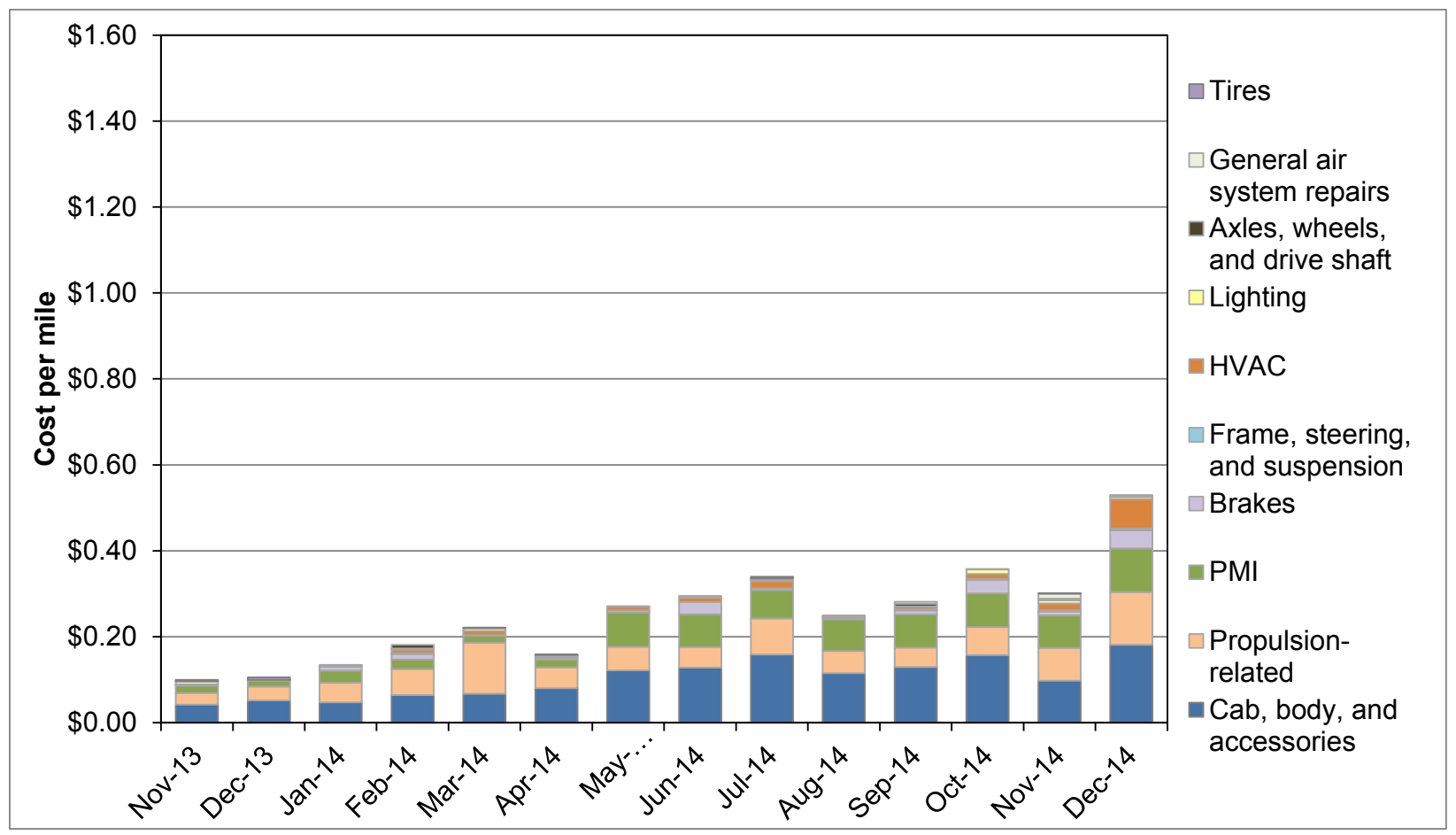

Figure G-6. Monthly cost per mile by category for the Gillig diesel buses 


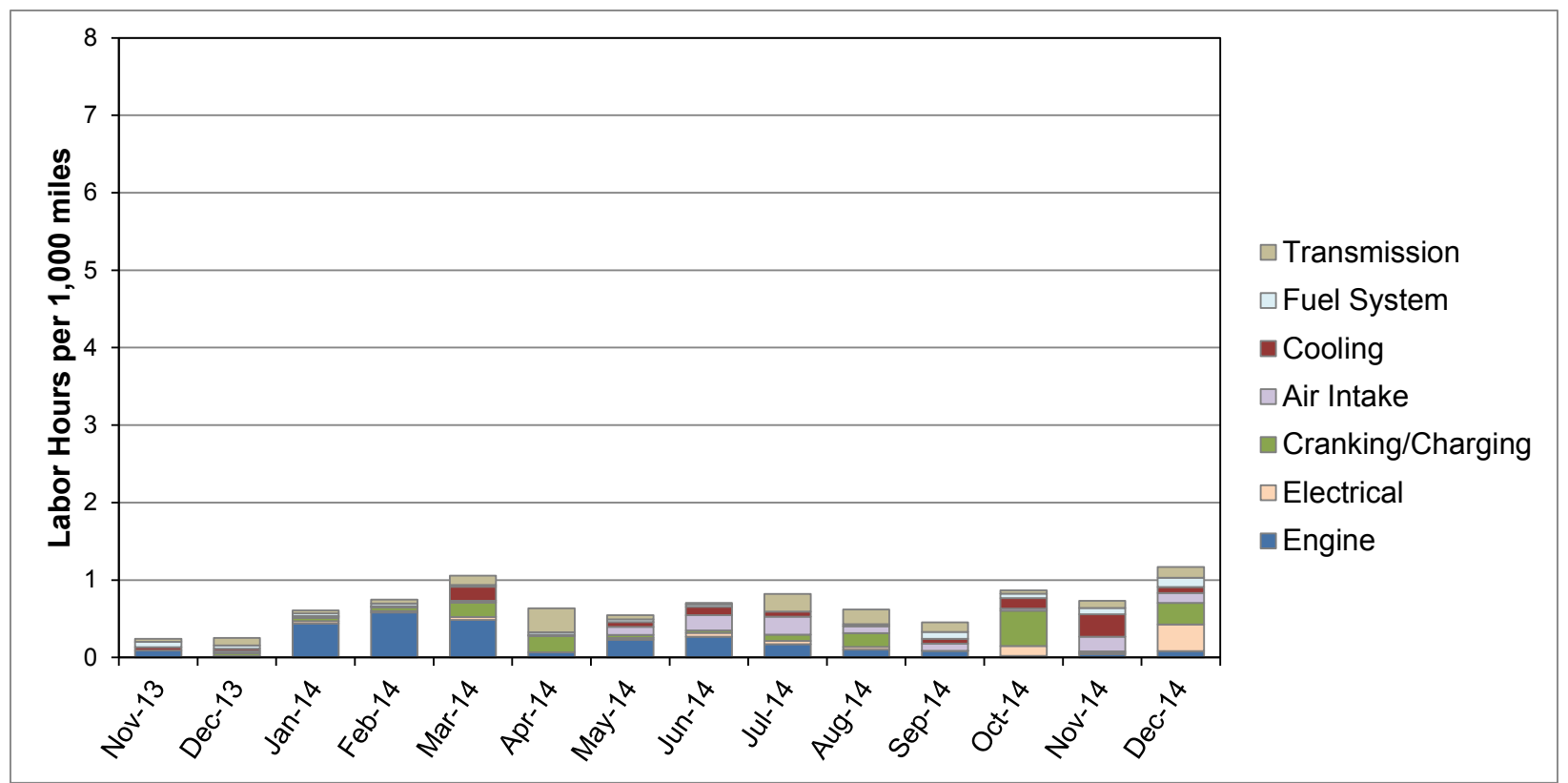

Figure G-7. Monthly propulsion system labor hours by sub-category for the Gillig diesel buses

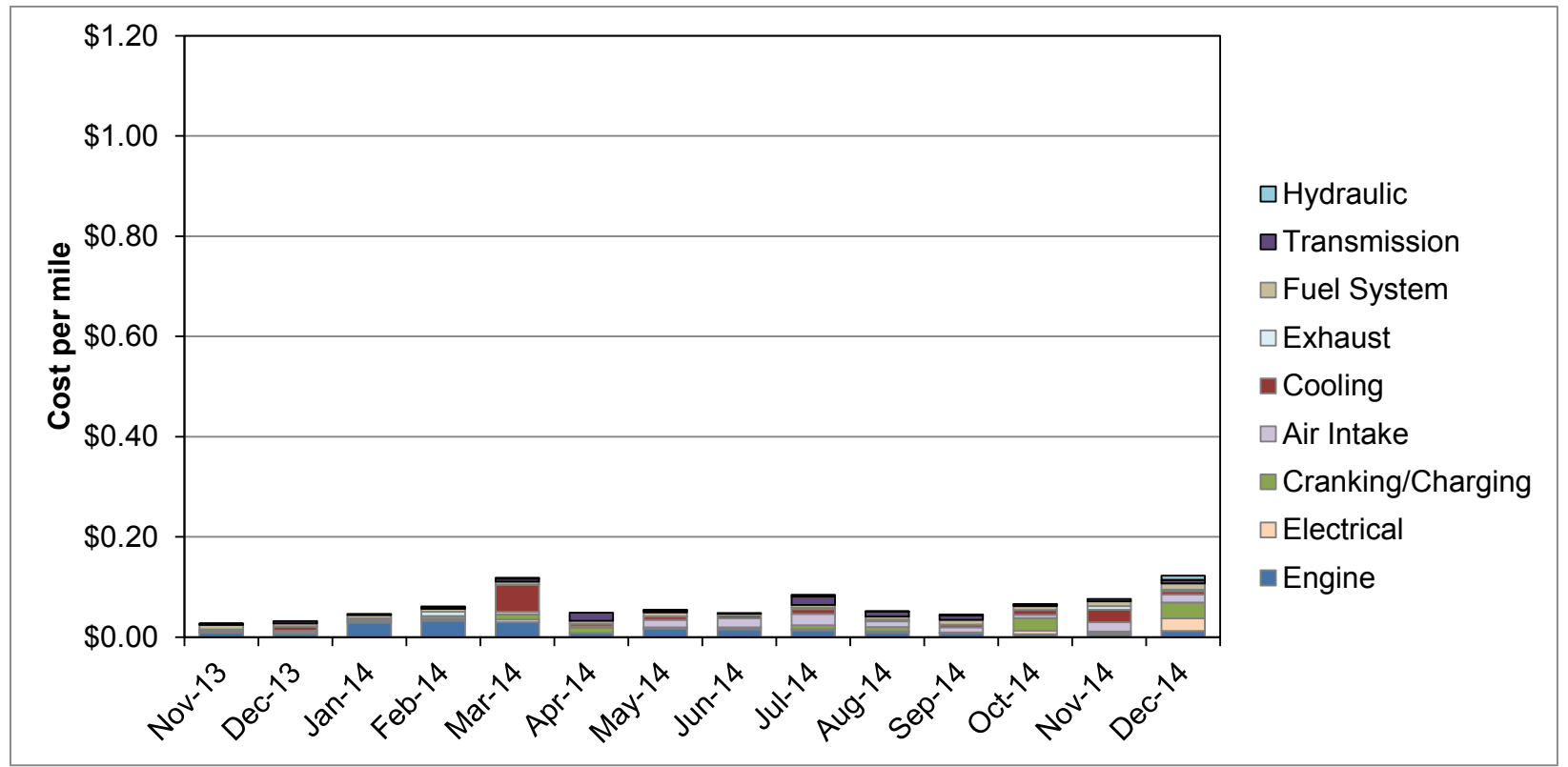

Figure G-8. Monthly propulsion system cost per mile by sub-category for the Gillig diesel buses 